INTER NATIONAL MONETARY FUND

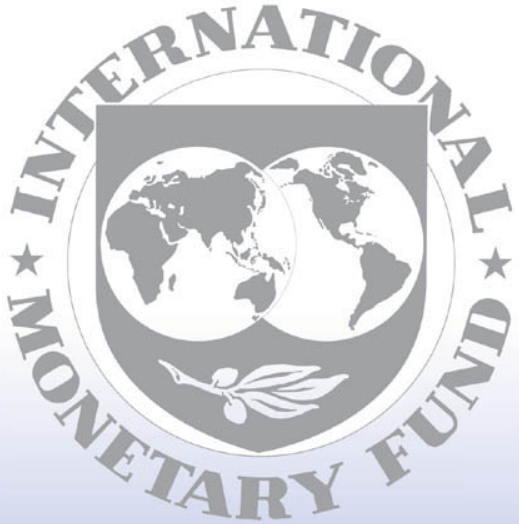

Staff

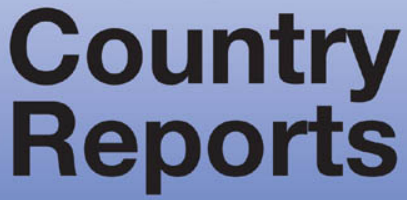


August 1997

IMF Staff Country Report No. 97/69

\section{Kingdom of the Netherlands-Netherlands-Selected Issues}

This selected issues report on the Kingdom of the Netherlands-Netherlands was prepared by a staff team of the International Monetary Fund as background documentation for the periodic consultation with this member country. As such, the views expressed in this document are those of the staff team and do not necessarily reflect the views of the Government of the Kingdom of Netherlands-Netherlands or the Executive Board of the IMF.

Copies of this report are available to the public from

International Monetary Fund • Publication Services

700 19th Street, N.W. • Washington, D.C. 20431

Telephone: (202) 623-7430 - Telefax: (202) 623-7201

Telex (RCA): 248331 IMF UR

Internet: publications@imf.org

Price: $\$ 15.00$ a copy

\section{International Monetary Fund \\ Washington, D.C.}


This page intentionally left blank 
INTERNATIONAL MONETARY FUND

\title{
KINGDOM OF THE NETHERLANDS-NETHERLANDS
}

\author{
Selected Issues \\ Prepared by a staff team consisting of C.M. Watson (head), Bas Bakker, \\ Ioannis Halikias, and Nancy Wagner (all EU1) \\ Approved by European I Department
}

June 3, 1997

Contents

Page

The Netherlands: Experience with Macroeconomic and Structural Reforms ........................... 5

Executive Summary ........................... 5

I. Introduction .....................

II. The Economic Setting in the Early 1980 s . . . . . . . . . . 8

A. Introduction $\ldots \ldots \ldots \ldots \ldots \ldots \ldots \ldots \ldots \ldots$

B. Key Features of the Economic Deterioration Prior to $1982 \ldots$. .9

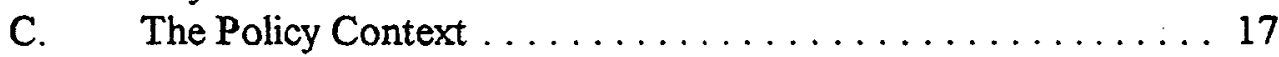

III. Policies in the 1980 s and 1990 s ................... 21

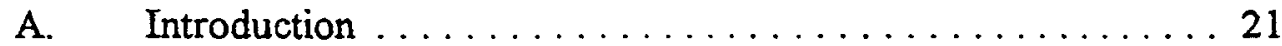

B. Wage Moderation .........................

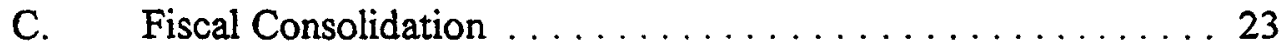

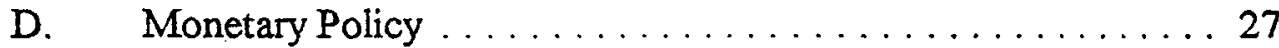

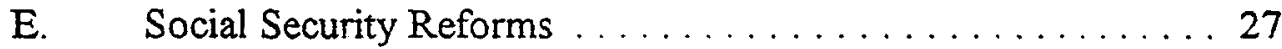

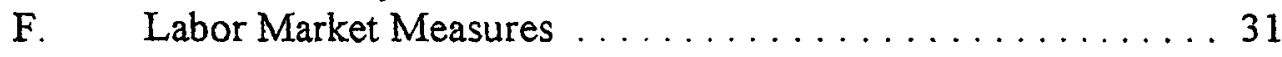

G. Product Market Measures .................. 35

IV. Economic Recovery Since the Early 1980 s . . . . . . . . . . 36

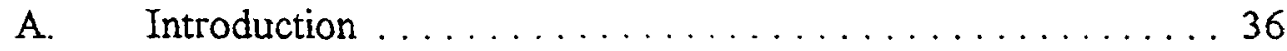

B. Economic Growth .................... . . . . .

C. Prices, Interest Rates and the Exchange Rate . . . . . . . . 44

D. Labor Market ........................ 45

CInternational Monetary Fund. Not for Redistribution 
V. An Analysis of the Wage Gap ................... 53

VI. Sources of Employment Growth $\ldots \ldots \ldots \ldots \ldots \ldots \ldots \ldots 61$

A. Wage Moderation and Employment Growth ...........62

B. The Impact of Policies and Economic Fundamentals on

Employment Growth

C. Impact of Fiscal Policy on Employment Growth:

Some Qualifications ....................668

D. Wage Moderation and Economic Fundamentals . . . . . . . . . 70

E. The Relevance of Supply-Side Policies . . . . . . . . . . . . 72

F. Employment Growth and the Broader Policy Setting ....... 74

VII. Assessing the Current Outlook ................... 76

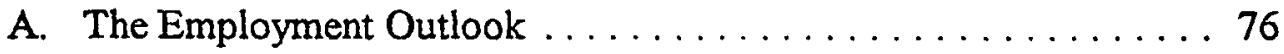

B. The Long-Run Fiscal Outlook . . . . . . . . . . . . . 79

Text Boxes

1. Policy Reform Measures in the Netherlands: An Overview ....... 22

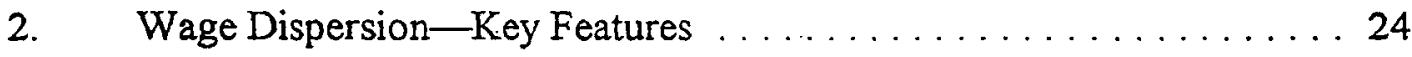

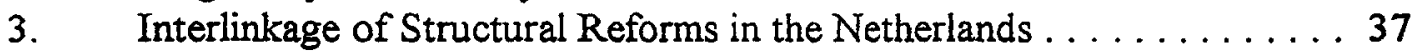

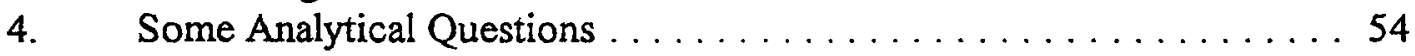

5. Employment Creation in the 1980s: The View of the Central

Planning Bureau ......................63

6. Is the Experience with Policy Reform in the Netherlands Replicable? . 80

$7 . \quad$ The Pension System-An Overview $\ldots \ldots \ldots \ldots \ldots \ldots \ldots \ldots 8 . \ldots \ldots$

$8 . \quad$ Health Care: The Present Dutch System $\ldots \ldots \ldots \ldots \ldots \ldots \ldots 83$

9. Generational Accounting in the Netherlands $\ldots \ldots \ldots \ldots \ldots \ldots 84$

\begin{tabular}{|c|c|}
\hline & \\
\hline 1. & International Comparisons: GDP Per Capita, 1970-1982 \\
\hline 2. & Labor Income Share. \\
\hline 3. & Real Private Consumption and Private Investment, 1970-1982 \\
\hline 4. & Employment, 1970-1982 \\
\hline 5. & Labor Market Indicators, $1970-1982$ \\
\hline 6. & Housing Market Developments, 1970-1982 \\
\hline$\overline{7}$. & Fiscal Policy, 1970-1982 \\
\hline 8. & Exch \\
\hline 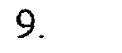 & cy, 1970-1996 \\
\hline 10. & Exchange and Interest Rate De \\
\hline 11. & External Indicators \\
\hline 12. & Labor Market \\
\hline 3. & Average Wedge Priv \\
\hline 4. & International Comparisons: GDP Per Capita, 1982-1996 \\
\hline
\end{tabular}


15. Real Private Consumption and Private Investment, 1982-1996 . . . . 39

16. Housing Market Developments, 1970-1996 . . . . . . . . . . . 41

17. Volume of Value Added in Exposed and Sheltered Sectors . . . . . . 42

18. Labor Productivity Growth . . . . . . . . . . . . . . . . . 43

19. Labor Market Indicators, $1980-1997 \ldots \ldots \ldots \ldots$

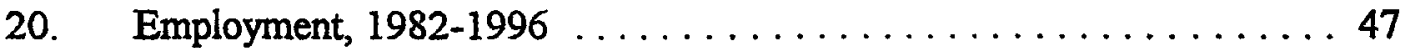

21. Employment in Exposed and Sheltered Sectors . . . . . . . . . .49

22. Labor Market Indicators, $1970-1996 \ldots \ldots \ldots \ldots \ldots \ldots$. . . . . . . 50

23. Unemployment Rate and Unemployment Benefits Recipient Rate ... . . 51

24. Unemployment and Disability Benefits Recipients . . . . . . . . 52

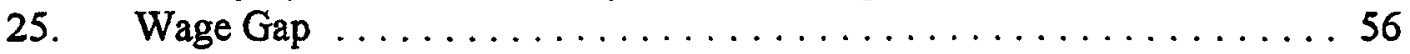

Appendices

I. The Wage Gap: A Cobb-Douglas Specification . . . . . . . . . . 86

II. Medium- and Long-Term Fiscal Scenarios . . . . . . . . . . 87

Appendix II Charts

26. Long-Term Fiscal Scenarios . . . . . . . . . . . . . . . 88

26a Long-Term Fiscal Scenarios - continued . . . . . . . . . . . . . 89

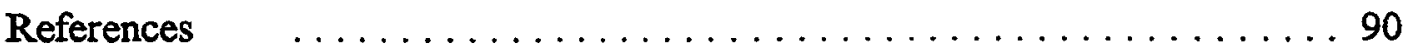

Table

1. Youth Minimum Wages . . . . . . . . . . . . . . . . . . . 32

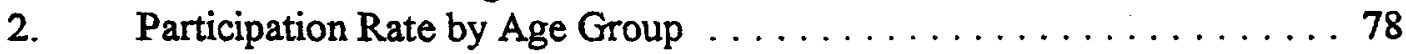

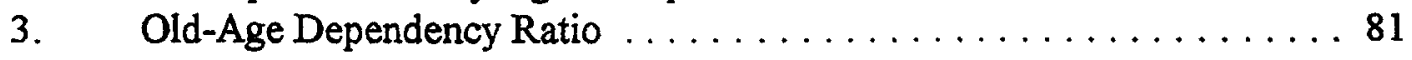

Statistical Appendix Tables

4. Aggregate Demand . . . . . . . . . . . . . . . . . . . 9 91

$5 . \quad$ Personal Income, Consumption, and Household Saving . . . . . 92

6. Private Consumption of Goods and Services . . . . . . . . . . 93

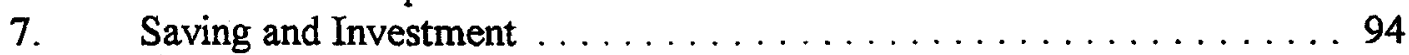

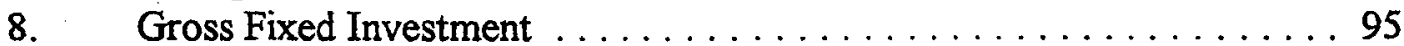

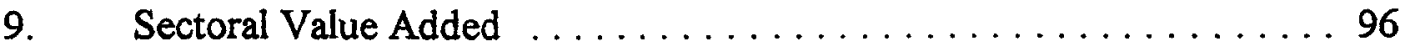

10. Selected Labor Market Indicators $\ldots \ldots \ldots \ldots \ldots \ldots \ldots \ldots \ldots \ldots$

11. Sectoral Distribution of Employment $\ldots \ldots \ldots \ldots \ldots \ldots \ldots \ldots$

12. Decomposition of the Increase in the Consumption Deflator . . . . . . . 99

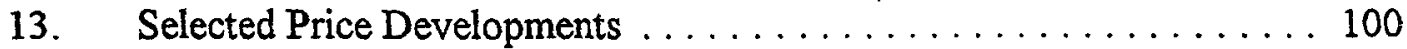

$14 . \quad$ Compensation per Employee and Average Tax Wedge . . . . . . . . 101

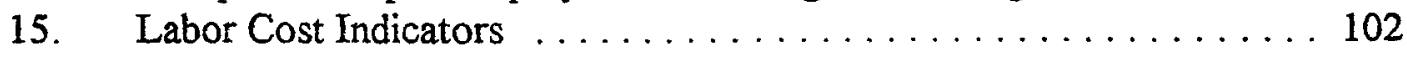

16. Revenues and Expenditures of General Government:

Economic Classification . . . . . . . . . . . . . . . . . . . 103

17. Expenditures of General Government: Functional Classification . . . . 104

18. Deficit and Debt of General Government ............. 105 
19. Social Security Expenditure $\ldots \ldots \ldots \ldots \ldots \ldots \ldots \ldots \ldots$

20. Social Security: Number of Recipients of Income-Replacing Benefits . 107

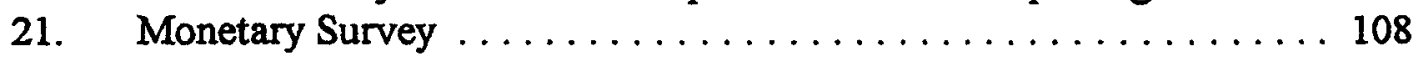

22. $\quad$ Key Interest Rates $\ldots \ldots \ldots \ldots \ldots \ldots \ldots \ldots \ldots \ldots \ldots \ldots \ldots, 109$

23. Exchange Rate Developments $\ldots \ldots \ldots \ldots \ldots \ldots \ldots \ldots \ldots 110$

24. Summary Balance of Payments $\ldots \ldots \ldots \ldots \ldots \ldots \ldots \ldots \ldots 111$

25. Current Account on a Transactions Basis $\ldots \ldots \ldots \ldots \ldots \ldots \ldots \ldots 112$

26. Merchandise Trade (Customs Basis) $\ldots \ldots \ldots \ldots \ldots \ldots \ldots \ldots \ldots \ldots$

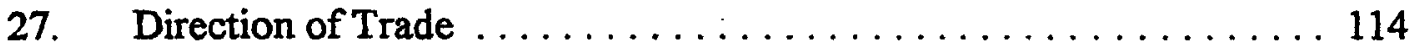

28. Official Development Assistance $\ldots \ldots \ldots \ldots \ldots \ldots \ldots \ldots \ldots \ldots \ldots$ 


\section{EXPERIENCE WITH MACROECONOMIC AND STRUCTURAL REFORMS}

\section{Executive Summary}

Since the early 1980 s, a major program of economic reforms has been implemented in the Netherlands. At the outset, the authorities and the social partners recognized that a fundamental change in policy approach was needed to address very serious macroeconomic and structural problems. The reforms, which were introduced gradually and in a consultative manner, were comprehensive in their coverage. They included a credible monetary policy, based on a tight link to the deutsche mark; expenditure-based fiscal consolidation, which allowed reduction of the tax burden as well as the fiscal deficit; and measures to stimulate both the supply and the demand side of the labor market. Latterly, product market reform has been added. These reforms were paralleled by a sea-change in labor union attitudes, reflected in enduring wage moderation.

The policies introduced were essentially orthodox in nature. Fiscal consolidation was a centerpiece of the reform effort. Public spending declined from nearly 67 percent of GDP in 1983 to just over 54 percent in 1996 . The general government deficit was reduced from 91/2 percent of GDP in 1982 (or 61/2 percent excluding on-lending) to $21 / 4$ percent in 1996 - and at the same time revenue was cut from 58 percent of GDP in 1983 to 52 percent in 1996. In the strategy of fiscal adjustment, the tightening of benefit provision was particularly important: it stimulated labor supply and job search, and also contributed significantly to public spending restraint, thus facilitating a reduction in the tax wedge and the fiscal deficit. Together, these factors helped entrench wage moderation and underpin the exchange rate anchor, facilitating a consistent and credible monetary policy.

Wage moderation-which cut the labor income share in the value added by firms by 10 percentage points-was triggered by a change in labor union attitudes, in the face of mounting unemployment and a macroeconomic crisis. It played a key role, accounting for perhaps half of the employment gains. It was consensual, in that labor unions came to view unduly high wages as destroying jobs. However, fiscal and labor market reforms played a major role in sustaining the change in wage behavior. The Government in effect changed the rules of the game in the labor market - cutting benefits and minimum wages, while offering income gains through tax cuts under a new fiscal strategy. There was no "consensus" on the benefit or minimum wage cuts; but the overall strategy came to be accepted as delivering growth, jobs, and social protection.

The labor market and associated social security reforms focused on measures to strengthen labor supply as well as labor demand. Measures to encourage participation in the labor force and job search included: lowering the replacement ratio for unemployment and disability benefits from 80 percent to 70 percent; shortening the duration period for unemployment benefits; tightening eligibility criteria for social benefits, particularly disability; cutting the tax burden on persons; and, most recently, privatizing sickness benefits. Measures to stimulate labor demand included: substantially cutting real minimum wages, especially for youths; 
reducing social premiums across the board; further reducing non-wage labor costs specifically for the low-skilled, and, most recently, virtually eliminating employers' social contributions for the low-skill long-term unemployed. Product market deregulation has now been added to the agenda of structural reforms, with measures launched to extend shopping hours, toughen the anti-cartel law, and lower entry barriers. The aim is to increase domestic competition, business creation, and jobs-notably in services-and these initiatives provide a crucial complement to continuing labor market reform.

The impact of the measures implemented over the past 15 years has been mutually-reinforcing, and a virtuous circle has emerged. Recent performance has featured very favorable growth rates both of economic activity and employment; and this, in turn, has facilitated the continuing task of fiscal adjustment. At the same time, this performance needs to be seen in perspective-particularly when seeking to assess the relevance of the reforms to policy priorities for the future and to problems faced in other economies.

First, recovery from the crisis in the early 1980 s has in part reflected special factors, including a large initial wage gap, favorable demographics, and low initial female participation in the labor force. These factors formed a propitious setting for initiatives aimed at strengthening labor demand, which contributed importantly to employment growth. In more typical circumstances, such as the present, an even stronger emphasis on improving the supply side of the labor market, and possibly greater wage dispersion, might be needed to achieve comparable employment growth.

Second, the recent employment gains can be viewed in part as a catch-up with neighboring countries from a very serious starting situation. Indeed, even today, major structural problems in the economy remain to be tackled. Participation-adjusted for demographics and measured in full-time equivalents-remains low; and numbers on disability and unemployment benefits are still close to a record level. The overall tax burden also remains heavy, and the debt ratio excessive. The policy challenge for the medium- and long-term is therefore to press ahead with fiscal and structural reforms with a view to strengthening and extending the success achieved in recent years. In this connection, reforms to restrain the growth of the social security and health care spending, and to further strengthen the supply side of the labor market, appear particularly important.

In sum, the reform process in the Netherlands is far from complete: it is indeed continuing at the present time. However, neither the special initial conditions nor the elements of catch-up in the Netherlands detract from the general interest of this experience - and in particular the central importance of orthodox economic measures, both macroeconomic and structural, in achieving an improvement in economic performance. 


\section{INTRODUCTION}

1. Since 1982, the Netherlands has been engaged in an economic reform program that has aroused increasing attention. The experience has many facets-the turnaround from a serious economic crisis, following a broad range of policy changes; the concern to muster support for reform through consensual, or failing that consultative, policy implementation; a record of employment creation, recently, that has been enviable compared with that in neighboring economies - but also a significant "unfinished agenda," with levels of participation and employment still worryingly low, numbers on welfare little short of record levels, and the tax and the debt burdens, while declining, still very heavy.

2. The facts presented in this paper tend, at a minimum, to dispel superficial criticisms of this experience, and to make clear that there was no "Dutch miracle": the policy reforms were painful; the progress made has been tangible. Moreover, the design of policies, both macroeconomic and structural, emerges as orthodox: expenditure-based fiscal consolidation, demand and supply side reforms in the labor market, and latterly measures to enhance competition in product markets. However, the way in which these policies interacted appears to have been quite complex; and, among other features, the relationship between the initial conditions, the emergence of wage moderation, and the design of policy reforms bears careful scrutiny.

3. A fuller understanding of these issues is worthwhile, both to assess the remaining challenges for policy reform in the Netherlands and to shed light on the question how far the formulas adopted in the Netherlands may be relevant to other economies facing comparable problems. How relevant is it that wages were far out of equilibrium at the outset-a situation quite different from that prevailing in, say, Belgium or France today; that the labor force was benefiting from prolonged demographic growth; or that, initially, female participation was very low, so that a substantial pool of workers remained to be tapped?

4. The immediately following discussion, in Sections II to IV, presents some essential facts on policies and performance: the nature of the crisis in the early 1980s, and its sources; the policy remedies applied; and the subsequent recovery of employment and output. In Section V, the paper then examines developments in wages: how far these moved away from, and then returned toward, an equilibrium level; and how this experience compares with that in other countries. Section VI seeks to shed light on the question how much policies contributed to the recovery of employment, and the role of the wage formation process in this context; from these findings, some inferences are drawn about the replicability of the success achieved in the Netherlands. Finally, against this background, Section VII offers a brief assessment of the current situation-including the opportunities, through continuing structural reform, to enhance the prospects for growth and employment in the Netherlands over the medium and long term. 


\section{THE ECONOMIC SETTING IN THE EARLY 1980S}

\section{A. Introduction}

5. In the late 1970s and early 1980 s the economic situation in the Netherlands deteriorated dramatically, leaving the economy, by 1982, in a state of crisis:

- A deep recession was underway: in 1982, real GDP declined for the second year in succession, with GDP per capita falling below the level of 1978 .

- The profitability of firms was close to zero: the capital income share in value added in 1982 was less than 5 percent-leaving no profits after interest payments.

- Unemployment had risen sharply-from 3 percent in 1979 to 8 percent in 1982.

- The fiscal deficit was increasing rapidly, reaching $91 / 2$ percent of GDP on a broad definition including on-lending (61/2 percent on a Maastricht definition) in 1982.

6. This situation resulted largely from developments that began early in the previous decade. Throughout the 1970s, wage growth was excessive, leading to a sharp erosion of business profits, while over the same period general government expenditure as a percentage of GDP rose by 21 percentage points, from 45 to 66 percent.

7. Overlaid on these underlying trends was the impact of developments in international energy prices, which gained particular attention in accounts of the so-called "Dutch disease". With higher energy prices, the natural gas revenues of the Government rose from under 1 percent of GDP in 1973 to 5 percent in 1981, and these additional revenues were in effect used to finance higher transfers to households. The increase in revenues is likely also to have exerted upward pressure on the exchange rate-which, in the absence of these windfalls, would probably have adjusted earlier. However, to keep these aspects in perspective, the overall increase in public spending was significantly greater than the counterpart of the additional energy receipts; and the crisis that triggered economic reform in the Netherlands in the early 1980 s preceded, by several years, the decline of world energy prices in $1986 .^{2}$

8. The task of government in recent years has been, in part, to redesign policies implemented in the course of the 1970s, so that the policy framework became more conducive

'Prepared by Bas Bakker.

"Some authors have argued that the evidence of the existence of a "Dutch disease" is not very strong, as the real exchange rate did not rise after 1974 (van Ark, de Haan, and de Jong 1996). However, is should be noticed that in 1974 the real exchange rate was about 30 percent higher than in 1960; it is very likely that in the absence of the increase in gas revenues the real exchange rate would have depreciated from this elevated level. 
to growth and employment creation in the private sector. To set recent policy approaches and economic performance in context, the remainder of this section reviews key features of the crisis that developed in the early 1980s, and its underlying sources.

\section{B. Key Features of the Economic Deterioration Prior to 1982}

9. During the period 1970-1982, the growth rate of GDP and GDP per capita was well below that of other European economies, and the gap increased during the course of the period. GDP per capita grew 7 percentage points less than in Germany, and 15 percentage points less than in Belgium and France. The underperformance was especially pronounced from 1979 onwards (Chart 1).

10. An important factor underlying this weak performance lay in wage developments. ${ }^{3}$ Wage growth accelerated in the 1960s, when the economy overheated. With wages automatically indexed to prices, the large terms-of-trade deteriorations in the non-energy economy in 1974 and 1979 did not lead to any compensating decline in real wages: the impact was instead felt by profits. In addition, a rapid increases in the collective burden of taxes and premiums also contributed to wage pressures; the brunt of these increases was, again, borne by profits.

11. During 1970-1982, with rapid wage growth, the income share of labor in firms' value added reached an unprecedented level: by the early 1980s, at 95 percent, it was 12 points higher than a decade earlier (Chart 2). The income share of capital declined from 17 percent in 1970 to less than 6 percent in 1980 . The profit share declined even more sharply as firms, which had increased their indebtedness in the 1970s, faced an environment of high interest rates. By the early 1980 s, the enterprise sector had virtually ceased to make profits.

12. Thus, during this period of rapid wage growth, competitiveness weakened and profitability declined, with negative effects on the overall level of investment: during the 1970-1982 period private investment was essentially flat (Chart 3). Wage increases did of course stimulate consumption, but from the mid-1970s onward this was to a large extent reflected in a deteriorating current account, rather than stronger output growth.

13. Rapid wage growth affected employment in two ways-through its impact on profitability, and thus new investment and job creation; and through the pressure on firms, over time, to change existing production processes so as to substitute capital for labor. While productivity increased, the balance between capital and labor, given the state of technology, moved substantially out of equilibrium. In the course of the early 1970s employment stopped growing, and by the early 1980s it started to decline. Moreover the pattern of employment shifted away from the private sector. Government employment increased by more than a quarter in the $1970 \mathrm{~s}$, but private sector employment declined-and by 1982 was 5 percent

\footnotetext{
${ }^{3}$ For a formal analysis of developments in wages since 1970 , see Section V below.
} 
CHART 1

NETHERLANDS

International Comparisons: GDP Per Capita, 1970-1982 $(1982=100)$
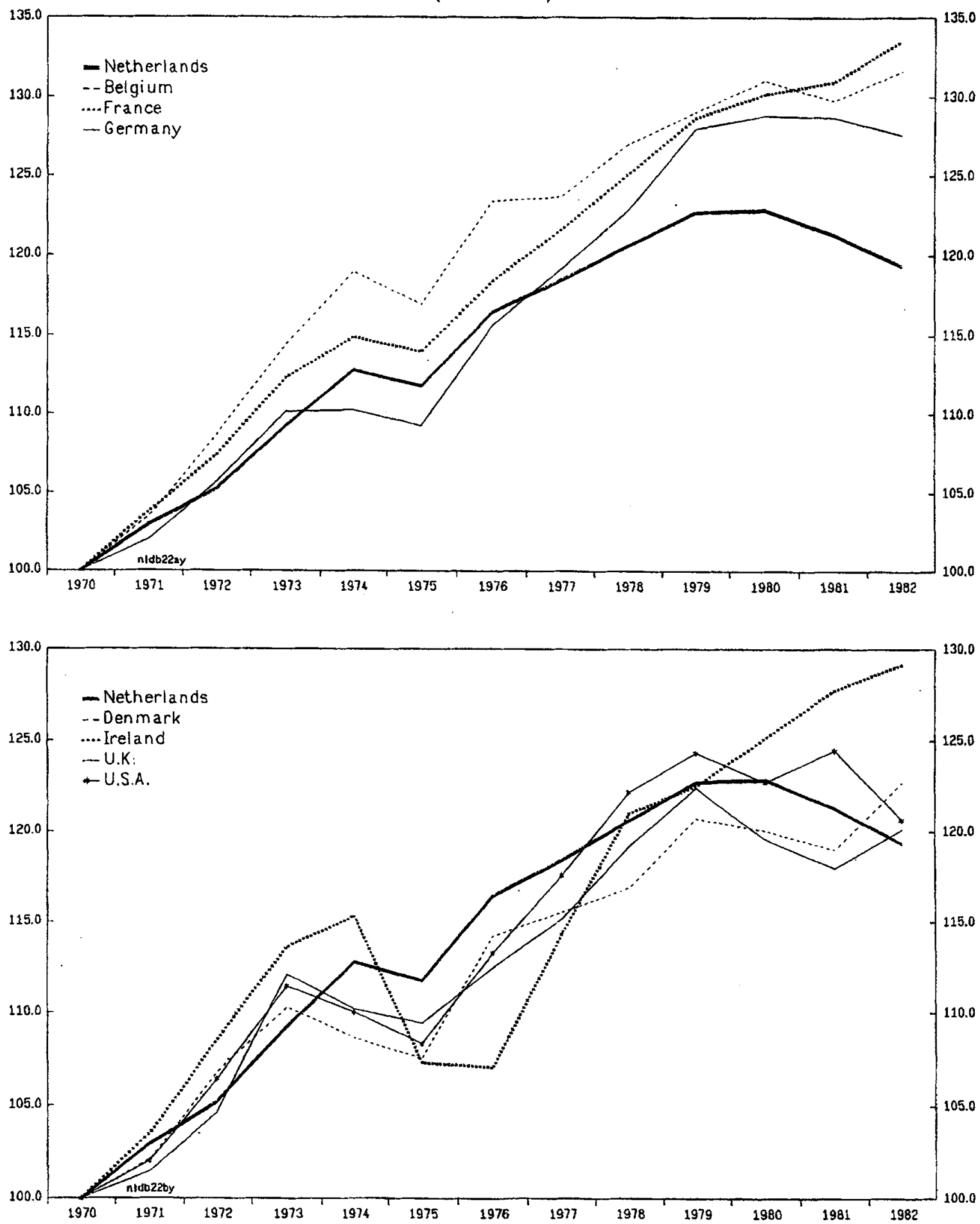
Source: IMF, World Economic Outlook. 
CHART 2

NETHERLANDS

Labor Income Share

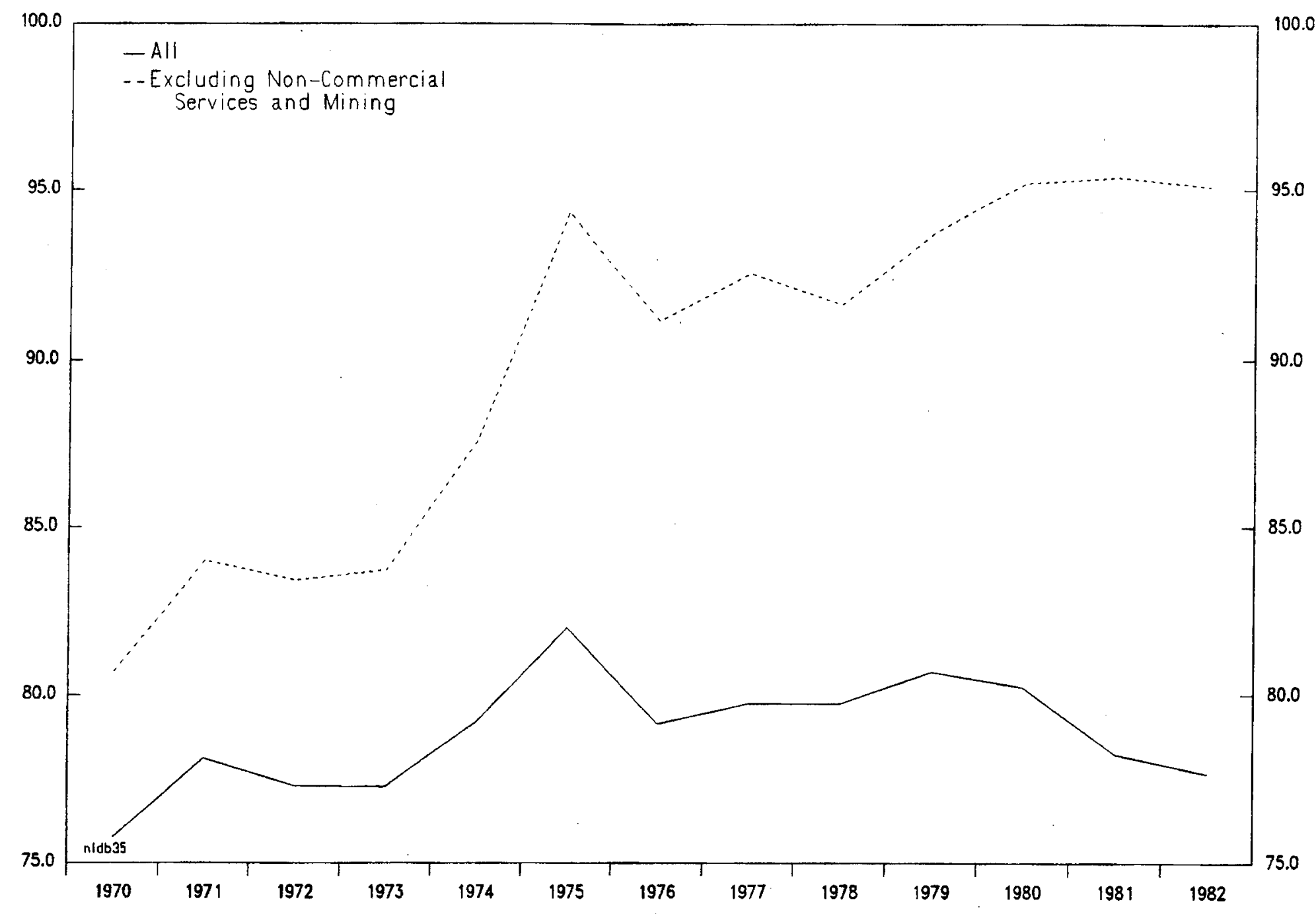

Source: Staff calculations. 
CHART 3

NETHERLANDS

Real Private Consumption and Private Investment, 1970-1982

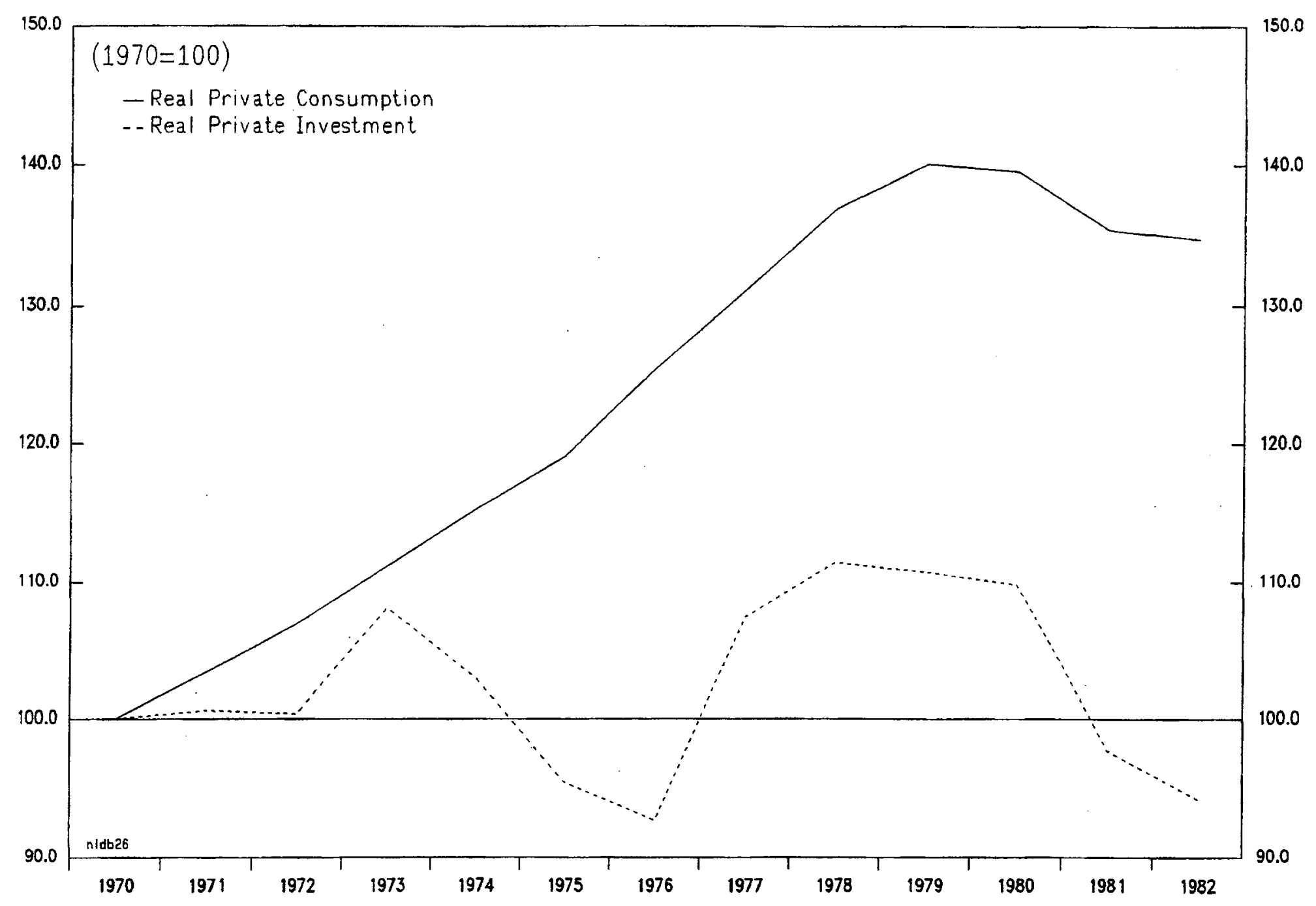

Source: OECD, Economic Outlook. 
lower than in 1970 (Chart 4). As a result, overall employment was about 2 percent lower in 1982 than in 1970. In persons, the picture was slightly less somber, as part-time employment increased.

14. Initially, the stagnation of employment growth was not reflected in a large rise in unemployment (Chart 5), as the participation rate of men declined strongly, from 87 percent in 1970 to 80 percent in 1979 . The participation rate of women remained virtually flat, at 34 percent-a relatively low level compared with that in neighboring countries. The decrease in the participation rate of men was in part associated with a sharp increase in the number of disability recipients, which rose from under 4 percent of the working age population in 1970, to some $71 / 2$ percent in 1982 . At the same time school enrollment rates increased from 8 percent of the working age population in 1970 to almost 12 percent in 1982.

15. In the early 1980s, employment declined strongly. During 1980-82, employment fell by 4 percent, as the steep downturn in economic activity forced firms to shed labor. At the same time, the labor force increased by 1 percent, as the decline in the participation rate of men no longer offset the increase in the working age population, and the participation rate of women, which thus far had been very low, started to increase. Unemployment thus finally began to rise sharply.

16. The underlying weakening of economic performance after 1975 was initially masked, and then, after 1978 heavily intensified, by a strong cycle in the housing market (Chart 6). Several factors appear to have lain behind the sharp increase in house prices in 1975-78. With very low, and at times negative, real long-term interest rates, mortgage borrowing was very attractive-particularly since interest payments were wholly deductible, including in higher tax brackets. Moreover, high consumer price inflation led households to acquire housing as a hedge. Finally, the rapid relative increase in house prices led to large wealth gains, which in part were made liquid through a rapid increase in mortgages, and thus stimulated consumption.

17. The collapse of the housing market after 1978 revealed the underlying weaknesses of the economy, and contributed to the severity of the recession. Real house prices declined very steeply, and by 1982 were 30 percent below the level of 1978. The collapse of the housing market led, symmetrically, to large wealth losses, and an ensuing negative impact on consumption: as households tried to improve their balance sheets in the face of declining housing prices and an increasingly heavy debt service burden, they cut back on other current spending. A vicious circle of declining expectations arose, as weak consumption fed recession, and this in turn exacerbated the housing market crisis. Overall, private consumption was flat in 1980, and declined in both 1981 and 1982. 
CHART 4

NETHERLANDS

Employment, 1970-1982

(In Full-Time Equivalents, $1970=100$ )

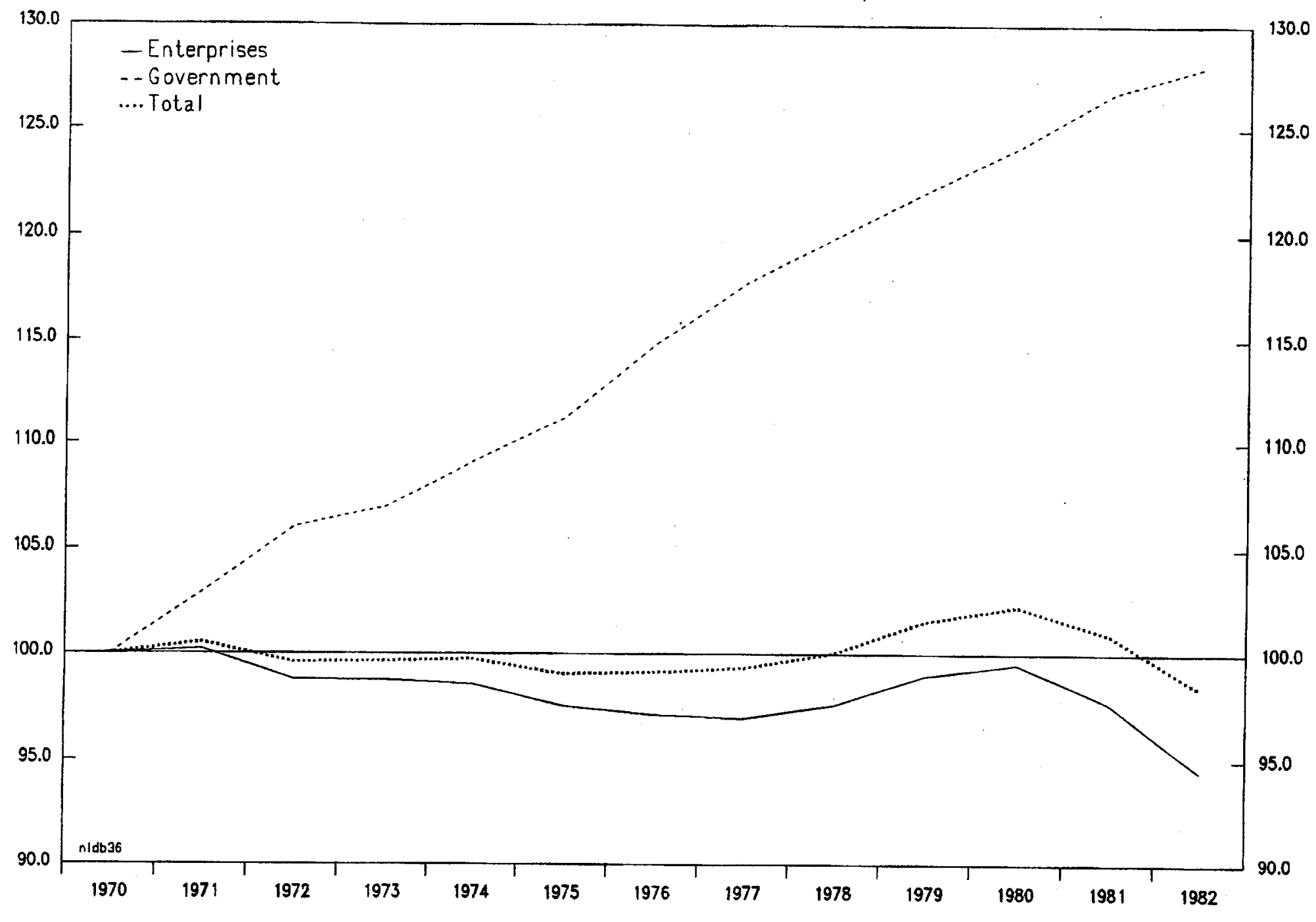

Source: Data orovided tov the Contral Plannina Ruroau 


\section{Labor Market Indicators, 1970-1982}
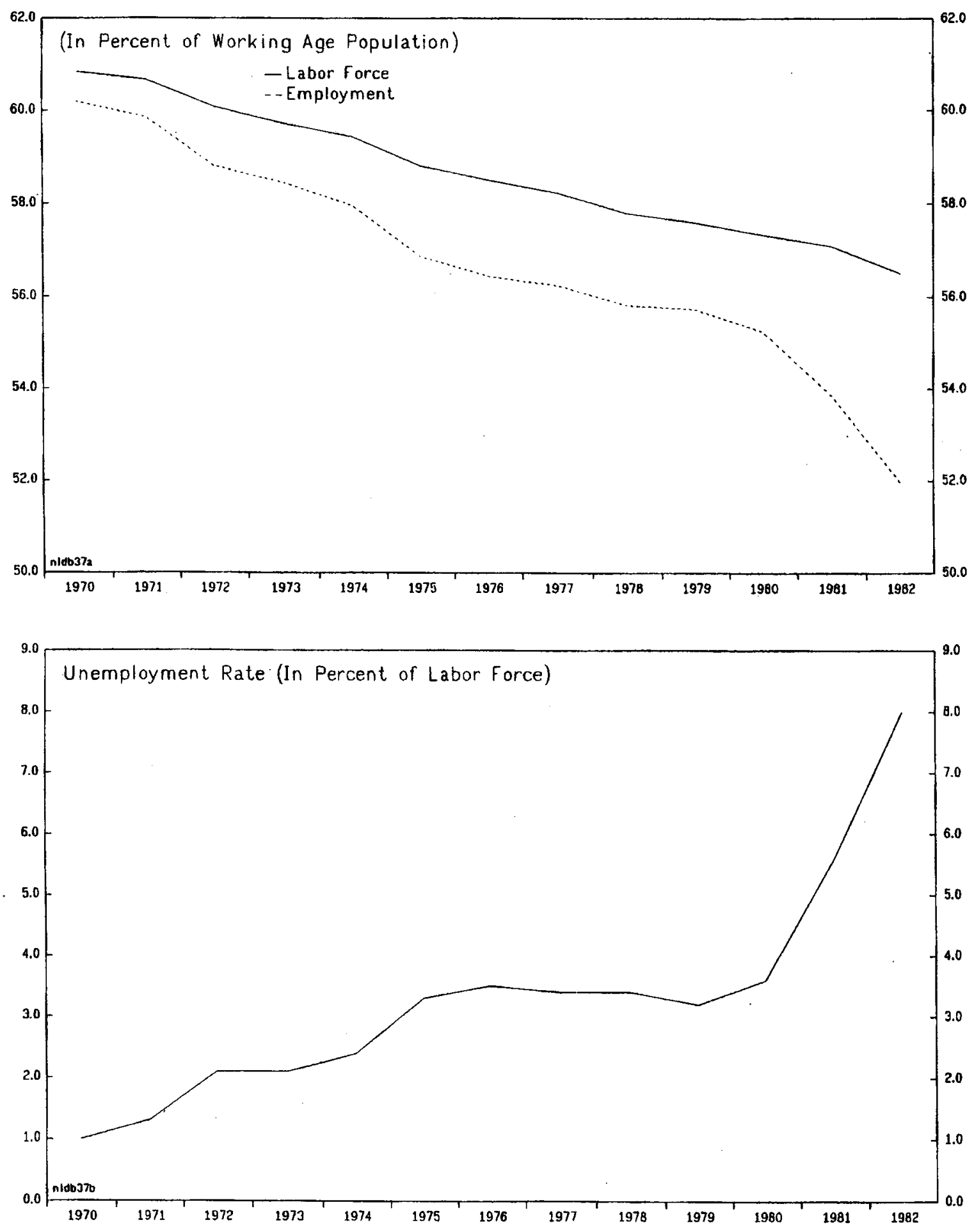

Source: Data provided by the Central Planning Bureau. 
CHART 6

NETHERLANDS

Housing Market Developments, 1970-1982
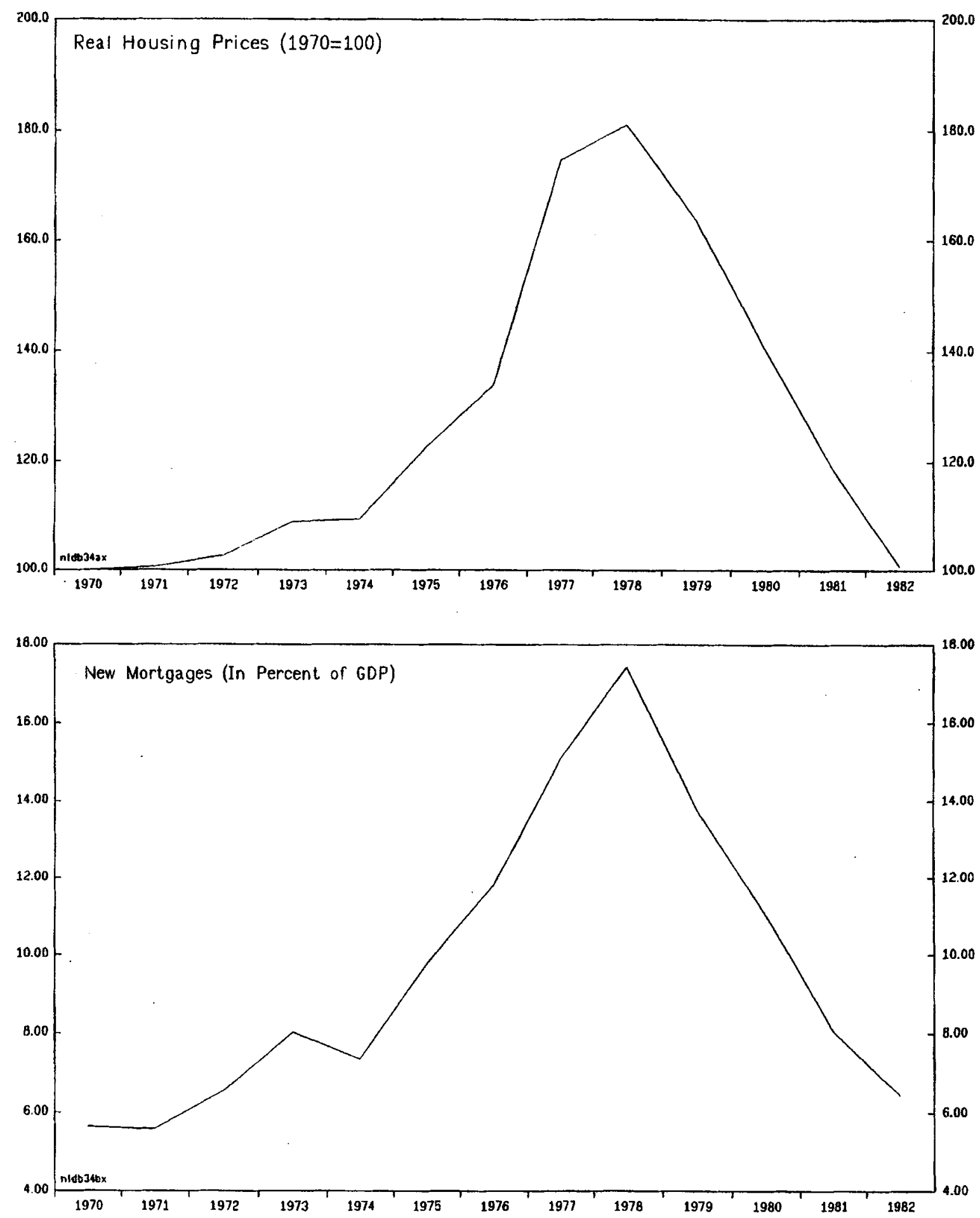

Sources: De Nederlandsche Bank; Central Bureau of Statistics; and staff calculations. 


\section{The Policy Context}

18. The sources of the deterioration in the economy in the period to 1982 can be traced to a constellation of macroeconomic and structural policies that did not favor the growth of economic activity and employment in the private sector.

19. During the 1970-1982 period, the fiscal situation deteriorated very seriously (Chart 7). Public expenditure rose sharply, mainly as a result of an increase in transfers to households. In twelve years, the expenditure/GDP ratio rose by nearly one half-from 45 percent in 1970 to 66 percent in 1982 . While almost all categories of spending increased relative to GDP, the growth in transfers to households was the most pronounced contributor; an important factor behind these rising transfers was the rapid increase in the number of social security recipients. The number of unemployment, disability, sick leave and welfare recipients more than doubled, from 8 percent of the working age population in 1970, to 18 percent in 1982.

20. Initially, the increase in public expenditure did not lead to a sharp increase in the fiscal deficit, since it was matched by a substantial increase in the collective burden of taxes and premiums. In 1978, the deficit, on a basis including on-lending, was some 4 percent of GDP, not far above the $2 \frac{1}{2}$ percent level of 1970 . Over this period, however, the revenue/GDP ratio rose by 11 percentage points, fueled by an increase in both taxes and premiums. However, when growth slowed, budget projections initially contimued to assume rather strong growth, leading to deficits that were much higher than had been targeted: after 1978, there was thus a very sharp increase in the fiscal deficit, which reached an unsustainable level by 1982: in four years, the deficit, including on-lending, rose by $51 / 2$ percentage points to $91 / 2$ percent of GDP. Excluding on-lending (i.e., on a Maastricht definition) the deficit rose by a similar amount, albeit to a somewhat lower level of $61 / 2$ percent of GDP. The sharp widening of the fiscal deficit took place in spite of a substantial increase in natural gas revenues-which rose from $3 / 4$ percent of GDP in 1973, to $21 / 2$ percent in 1977 , and 5 percent in 1981, as natural gas prices increased in line with petroleum prices.

21. Following the breakdown of the Bretton Woods system of fixed exchange rates in 1973, monetary policy was based on a link between the guilder and the deutsche mark (Chart 8). Until 1979 the guilder participated in the "snake" arrangement in Europe; thereafter it was a member of the European Monetary System (EMS). However the linkage to the deutsche mark was only partial, as a times the deutsche mark was revalued by more than the guilder. Inflation performance in the Netherlands was weaker than in Germany: from 1973 to 1982 prices rose by a cumulative 40 percentage points more than in Germany. The inflation differential largely reflected a more rapid increase of unit labor costs. It was in part offset by the de facto devaluation of the guilder against the mark, but the real exchange rate vis-à-vis Germany nonetheless appreciated by 34 percentage points during this period. 


\section{$-18-$ \\ CHART 7 \\ NETHERLANDS}

Fiscal Policy, 1970-1982

(General Government, In Percent of GDP)
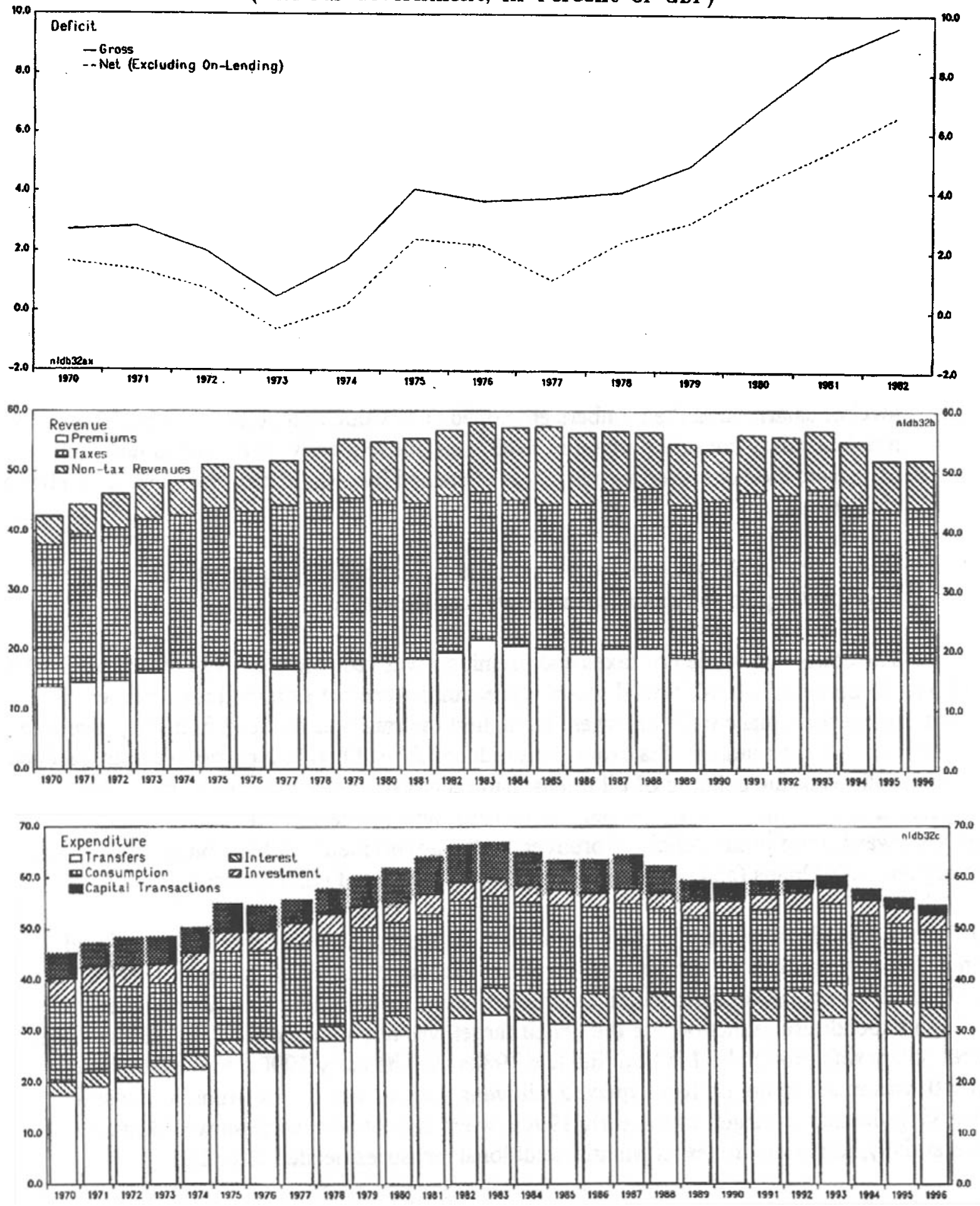

Sources: Ministry of Finance, Miljoenennota, 1997; and OECD, Economic Outlook. 
NETHERLANDS

Exchange and Interest Rate Developments, 1970-1982 (In Percent)
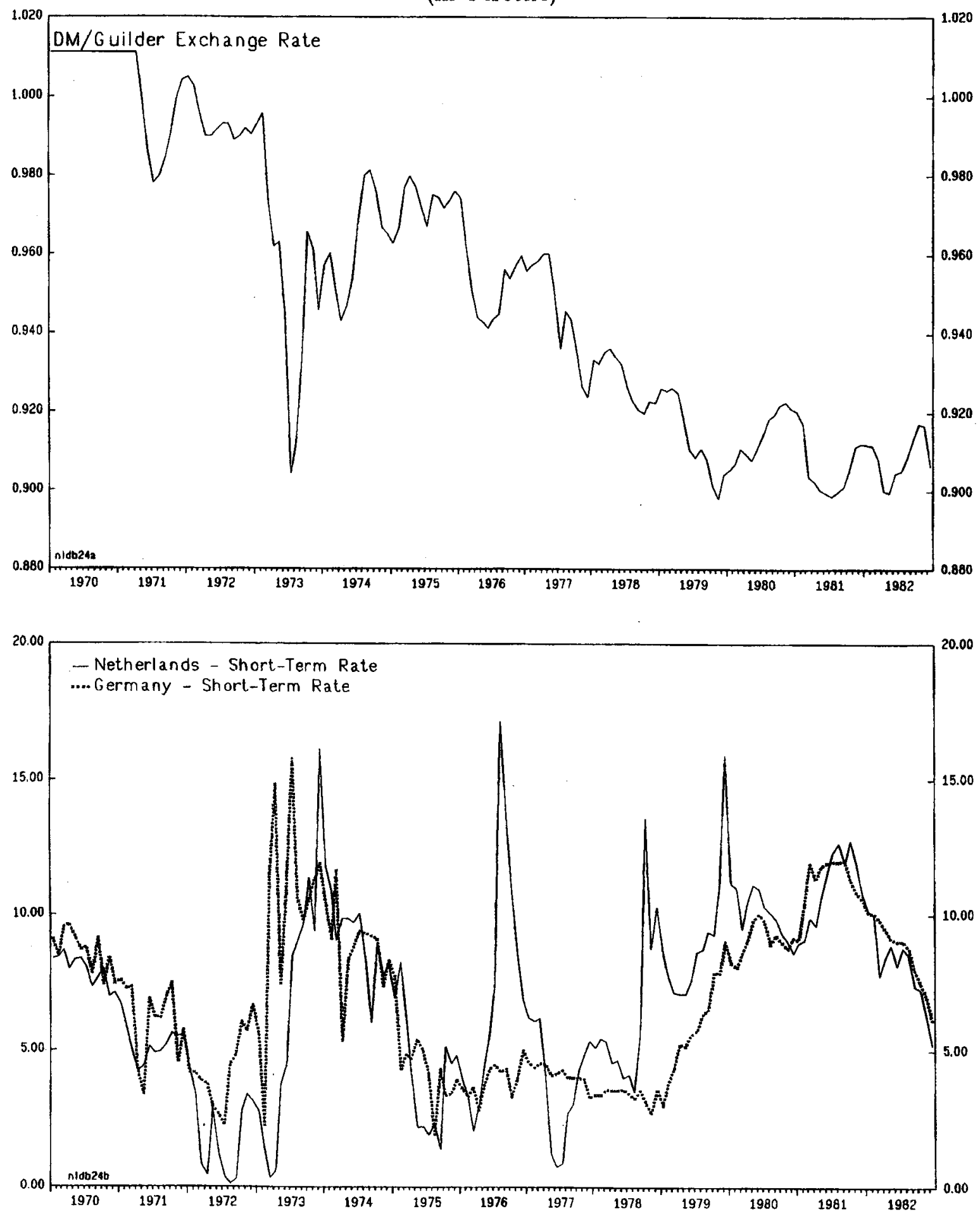

Source: IMF, International Financial Statistics. 
22. Overall, the exchange rate anchor clearly was not fully credible during this period. It was, indeed, subjected to speculative attacks. In December 1973, the brief oil boycott inflicted on the Netherlands caused a short but sharp flight from the guilder. Similar pressure arose in August 1976, after the Netherlands had declared the guilder would not follow suit in the event of a revaluation of the mark - which underscored the implications of the notable excess of Dutch inflation over German inflation. In October 1978, the guilder again came under pressure as a result of the planned introduction of the EMS: given the rapidly increasing current account deficit, the concern arose that the guilder would need to be devalued on entry.

23. Together with weak fiscal policy and a less than credible exchange rate anchor, labor market policies clearly contributed to the deterioration of economic performance, including the erosion of employment in the private sector. Problems in the labor market were exacerbated by increases in minimum wages, and the introduction of minimum wages for young people-for whom previously no minimum wages had existed. In 1971-78, the minimum wage was increased much more rapidly than the average wage-which itself was rising sharply. In 1974, a minimum wage for workers below 23 was introduced. The minimum wage was calculated as a percentage of the minimum wage for adults, and varied from 40 percent for the 15 -years old, to $921 / 2$ percent for people of age 22 . The introduction of a link between the minimum benefit and the minimum wage contributed to supply-side problems, especially at the lower end of the labor market. By setting the floor for all social benefits at the level of the net minimum wage, this policy sharply reduced incentives for the low-skilled to seek employment. More generally, the environment of sharply rising social benefits sent signals to the population that are likely to have discouraged labor force participation.

24. This policy environment was characterized by a number of linkages, which resulted in the development of a vicious circle in economic performance. As social benefits increased, this both worsened labor market incentives and damaged the fiscal position. Excessive wage increases and declining participation were associated with slower economic growth and lower employment, aggravating the fiscal situation. When the worsening structural fiscal problem was addressed, action was initially on the revenue side: the resulting increase in the collective burden of taxes and premiums in turn exacerbated wage pressures, and was translated largely into a lower profit share. In this setting, the nominal link of the guilder to the deutsche mark, rather than protecting the economy from inflation, was associated with a substantial real exchange rate appreciation vis-à-vis Germany-thus serving as a transmission channel for deflationary effects on the economy.

\footnotetext{
${ }^{4}$ See Den Dunnen (1985).
} 


\section{Policies IN THE 1980S AND 1990s}

\section{A. Introduction}

25. The year 1982 represented a watershed in economic policy: a new government took office, with the objective of pursuing fiscal consolidation and, in a number of respects, reducing the intervention of the state in the economy. In addition, agreement was reached between the labor unions and the employers on the need for wage moderation, which has since prevailed. From then on, through the mid-1990s, policies have been based on fiscal consolidation, a tight and credible link of the guilder to the deutsche mark, and wide-ranging structural reforms- particularly in the related areas of social security and the labor market (Box 1).

\section{B. Wage Moderation}

26. Wage moderation was triggered in 1982 by a consensus between the social partners on its beneficial impact on employment creation; it was underpinned by a shift in government policies toward the labor market, some elements of which were far from consensual in nature.

27. The initial consensus on the necessity of wage moderation appears to have resulted from experiences in the 1970s. The combination, in the early 1970s, of substantial GDP growth and stagnating employment had cast doubt on the view that unemployment was a Keynesian problem, and stimulated the idea that persistent unemployment was caused not by insufficient effective demand but by a lack of profitable productive capacity. This idea was underscored by the introduction at the Central Planning Bureau (CPB) of a new generation of models, which contained supply-side as well as demand-side elements (den Hartog and Tjan (1974)). According to these models, the excess growth of real wage costs over the rate of technical progress affected employment in two ways: first, it led to scrapping of old laborintensive vintages of capital; and second, it implied lower profitability, which resulted in a lower level of investment, a slower growth of the capital stock, and fewer new jobs.

28. The gradually emerging consensus on the necessity of a different strategy on wages was formalized in late 1982, when labor unions and employers in the "Wassenaar Agreement" agreed to moderate wage growth in order to stimulate employment creation. Although wage growth had already slowed down substantially in the late 1970 s, real contract wages still went up by some $2 \frac{1}{2}$ percent in 1982 -at a time the country was in a deep recession. Wage moderation went into effect from 1983, and continued after the economy began to recover from recession; the beneficial impact on employment creation was widely felt and recognized. By the late 1980s, wage moderation had become a virtually unchallenged policy recipe among labor unions, employers, and political parties in the Netherlands.

\footnotetext{
'Prepared by Bas Bakker.
} 


\section{Box 1. Policy Reform Measures in the Netherlands: An Overview}

Since the early 1980s, reforms have included a credible monetary policy, expenditurebased fiscal consolidation that has cut both the tax burden and the fiscal deficit, and measures to stimulate both the supply and the demand side of the labor market; these reforms have been paralleled by an enduring change in labor union attitudes.

- Fiscal consolidation, as a centerpiece of the reform effort, was characterized by a decline in spending from nearly 67 percent of GDP in 1983 to just over 54 percent in 1996 (including cuts in social transfers, control of wage costs, and structural measures to restrain health care spending); a reduction in the general government deficit from $91 / 2$ percent of GDP in 1982 (or 61/2 percent excluding on-lending) to $21 / 4$ percent in 1996; and a decline in revenue from 57 percent of GDP in 1983 to 52 percent in 1996. Consolidation was initially achieved through deficit targeting, with a shift in 1994 to medium-term expenditure norms.

- Monetary policy-through a link to the deutsche mark - was consistent and credible.

- Wage moderation-which cut the labor income share in the value added by firms by 10 percentage points-was triggered by a change in labor union attitudes, in the face of mounting unemployment and a macroeconomic crisis; but fiscal and labor market reforms played a role in sustaining the change in wage behavior (for a discussion, see Box 2).

- Labor market and associated social security reforms focused on measures to encourage labor supply and job search as well as labor demand:

- Measures to improve the supply of labor and job search included: lowering the replacement ratio for unemployment and disability benefits from 80 percent to 70 percent; shortening the duration period for unemployment benefits; tightening eligibility criteria for social benefits, particularly disability; cutting the tax burden on persons; and, most recently, privatizing initial sickness benefits.

- Measures to stimulate labor demand included: substantially cutting real minimum wages, especially for youths; cutting social premiums across-the-board; reducing non-wage labor costs for the low-skilled (lowering their labor costs by currently some 5 percent), and, most recently, virtually eliminating employers' social contributions for the low-skill long-term unemployed (cutting the labor cost of such workers by 17 percent).

- Product market deregulation has now been added to the agenda (longer shopping hours, tougher anti-cartel law, lower entry barriers, reduced administrative burden), with a view to increasing domestic competition, business creation, and jobs-notably in services. 
29. An important element of the 1982 agreement was the decentralization of wage bargaining. Whereas before 1982, unions and employers' organizations sought agreement at the national level, henceforth negotiations took place at the sectoral level only. The degree of change in the process of decentralization is, however, debatable. Although before 1982, agreement was always sought at the national level, negotiations were largely unsuccessful in the 1970s, leading to subsequent negotiations at the sectoral level. Moreover, after 1982 there was a high degree of coordination within labor unions' and employers' organizations at the national level. Thus, both before and after 1982, wage increases have varied only moderately across sectors. Nonetheless, the degree of sectorial variation was somewhat greater than in neighboring countries (see below).

30. Wage moderation was encouraged by the Government in several ways. An important element in the approach was a reduction in the collective burden of taxes and premiums, which allowed real net incomes to rise, even in the absence of gross wage increases. Apart from that, the Government threatened on some occasions (such as in 1993) with intervention if it considered that negotiated wage increases were too high. Finally, the substantial cuts in the real minimum wage and in social benefits, and the decline in real government wages, are likely to have underpinned continuing wage restraint in the private sector.

31. Other factors that favored wage moderation included a rapid rise in the participation of women, and a strong increase in the working age population: with a sizable increase in labor supply, wage pressures were less likely to emerge. Indeed, in the absence of reforms on the demand side of the labor market, unemployment would clearly have risen very steeply. However, there may also have been an indirect influence in the other direction: wage moderation, through its positive impact on employment creation, is likely to have induced participation and thus a higher effective labor supply.

32. Finally, a somewhat puzzling aspect of labor market developments has been wage dispersion, which has risen little overall in the course of the past 15 years; however the dispersion of wages across sectors has increased significantly (Box 2). Recent initiatives have aimed to reduce the growing gap between legal and contract minimum wages, but results remain to be seen. ${ }^{6}$

\section{Fiscal Consolidation}

33. Fiscal policy aimed at restraining the growth of public expenditure, thereby creating room for both deficit reduction and a cut in the collective burden of taxes and premiums. Thus, public expenditure was reduced from 66 percent of GDP in 1982 to 54 percent in 1996, revenue from close to 57 percent of GDP to below 52 percent, while the broadly measured

\footnotetext{
${ }^{6}$ As the Government typically declares sectoral wage agreements generally binding, it has had some leverage to encourage the social partners to introduce new wage scales closer to the minimum wage.
} 


\section{Bor 2. Wage Dispersion-Key features}

\section{Wage dispersion}

According to OECD data, wage dispersion has increased only slightly since the mid-1980s.' From 1985 to 1995 , the ratio of earnings in the fitth decile to earnings in the first decile increased only from 1.55 to 1.56 , whereas the ratio of earnings in the ninth decile to earnings in the fitth decile increased from 1.62 to 1.66. Countries such as the United States and the United Kingdom have experienced far larger increases in wage dispersion. By international standards, wage dispersion in the Netherlands remains low. Wage dispersion is not only lower than in the United States and the United Kingdom, but also, for instance, than in France and Italy.

It may appear surprising that a substantial reduction of the ratio of the minimum wage to the average wage was not associated with a greater increase in wage dispersion. One explanation may lie in the fact that the lowest scales in collective labor agreements general rose in line with average wages, thus opening up a gap between the legal minimum wage and the actual minimum wage.

Although measured wage dispersion did not increase much, the reduction in the real minimum wage may still have had beneficial supply side effects. As minimum benefits are linked to the legal minimum wage, a widening of the gap between the actual minimum wage and the legal minimum wage increases the difference between wages and benefits, thus improving incentives to find a job.

Although wage dispersion among employees economy-wide does not seem to be very high, earlier staff research would suggest that wage dispersion across sectors has been increasing significantly (SM/96/31). During 1987-1993, the standard deviation of wage increases among sectors in the Netherlands was similar to that in the United Kingdom, and notably higher than in some neighboring economies.

'OECD, Employment Outlook, July 1996. 
deficit declined from $91 / 2$ percent to $2 \frac{1}{2}$ percent of GDP (Chart 9). Net of on-lending, the deficit on the Maastricht basis fell from 61/2 percent of GDP in 1982 to 21/4 percent in 1996 (Chart 9).

The expenditure reduction was in large part the result of three policy approaches:

- The share of social transfers in GDP was cut by holding down the value of benefits. Due to a freeze of the minimum wage and minimum benefit, the delinkage of benefit growth from average wage growth, and the reduction of unemployment and disability benefit replacement rates from 80 percent to 70 percent of wages, social transfers were reduced as a percentage of GDP. The volume component contributed much less to expenditure reduction, as through most of the period the number of social security benefit recipients continued to rise.

- The civil service salary bill, as a percentage of GDP, was cut by containing both the level of salaries and the numbers employed. The value component was held down by a nominal salary cut of 3 percent in 1983, and, subsequently, very limited nominal increases; the volume component was contained by a slight reduction in the number of civil servants.

- On-lending by the state was cut substantially, and capital transfers to firms were in large part replaced by an accelerated depreciation system.

34. The collective burden of taxes and premiums was reduced from 48 percent of GDP in 1980 to 45 percent in 1996. Social security premiums were cut as transfers decreased. A major tax cut took place in 1990, when the highest tax rate was reduced from 72 percent to 60 percent, and the number of tax rates was reduced from 11 to 3 . Non-tax receipts declined as well: following the collapse of oil prices, natural gas revenues dropped sharply, from $43 / 4$ percent of GDP in 1986 , to $21 / 2$ percent in 1987 , and $13 / 4$ percent in 1988 , thus interripting the downward trend in the deficit. Moreover, as the government cut back on its on-lending, the repayment of loans (and hence non-tax receipts) decreased correspondingly.

35. As regards fiscal rules, from 1983 until 1993 the operational target was the fiscal deficit. Administrations set a time-path for the reduction of deficit financing as a percentage of GDP. Limits were set on the collective burden, thereby forcing deficit reduction to occur through expenditure reduction. As the deficit target was not adjusted for the business cycle, fiscal policy was pro-cyclical in both the late 1980s and the early 1990s. In the late 1980s, growth was much stronger than expected, allowing for expenditure overruns, while still observing the deficit target. In the early 1990s, when economic growth slowed down substantially, at various times substantial additional measures needed to be taken.

36. In 1994, a switch was made to a medium-term expenditure measures, with ceilings being set on spending by the central government, social security and health care. A time path was set for expenditure, based on conservative assumptions with regard economic growth. While ceilings were set on the fiscal deficit as well, the use of conservative assumptions 
CHART 9

NETHERLANDS

Fiscal Policy, 1970-1996

(General Government, In Percent of GDP)
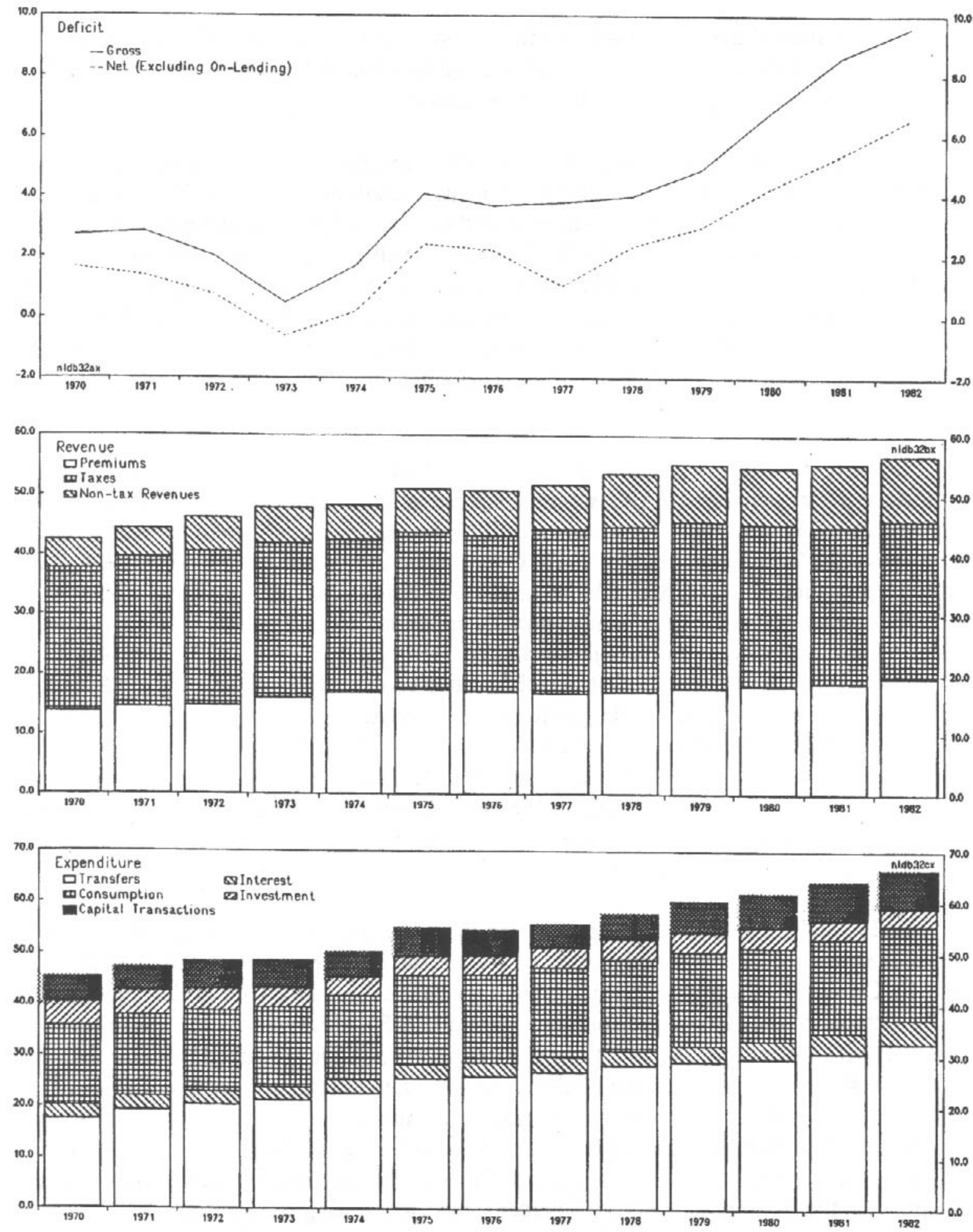

Sources: Ministry of Finance, Miljoenennota, 1997; and OECD, Economic Outlook. 
minimized the risk that additional measures would be needed, once annual budgets had been passed. If growth was higher than expected at the time the expenditure framework was set, the additional revenues would be used for both tax and deficit reduction; the expenditure ceilings would not be changed. Overall, spending in 1994-1996 was held below ceiling levels.

\section{Monetary Policy}

37. Monetary policy during the period from 1982 to the present has aimed solely at maintaining the fixed exchange rate link with the deutsche mark. Since a final devaluation in 1983, the guilder-deutsche mark parity has thus remained unchanged for almost 14 years. The credibility of the link was clearly established in the exchange rate market turmoils of 1992 and 1993, when the guilder-deutsche mark parity did not come under attack. Moreover, while the exchange rate bands of almost all EMS-currencies were widened, the guilder-deutsche mark exchange rate was left unchanged (Chart 10).This contrasts with the de facto devaluations against the deutsche mark of 1970s.

38. The combination of a nominal exchange rate link with better wage cost and inflation performance than Germany led to a substantial real exchange rate depreciation vis-à-vis Germany. Based on consumer price inflation, the real exchange rate has depreciated by 7 percent since 1982; based on unit labor costs the depreciation has amounted to 34 percent (Chart 11). The real exchange rate vis-à-vis other countries did not change greatly, as the better inflation and wage cost performance was offset by an appreciation of the nominal exchange rate. Thus, after a substantial decline of the real effective exchange rate in the early 1980s, the effective exchange rate has changed relatively little.

\section{E. Social Security Reforms}

39. The social security system has been reformed comprehensively since the early $1980 \mathrm{~s}$. The value of unemployment benefits was reduced, duration was shortened, and eligibility was tightened. Disability benefits also were reduced, and eligibility tightened. Sick leave benefits were first reduced and then progressively privatized.

As regards unemployment benefits:

- Before 1986, an unemployed worker who had worked for at least 130 days in the year preceding his unemployment, would receive for six months a premium-financed unemployment benefit (WW) of 80 percent of his last earned wage, followed by two years of a budget-financed unemployment benefit (WWW) of 75 percent of his lastearned wage (WWV). ${ }^{7}$ After two and half years of unemployment, the unemployed

\footnotetext{
'For married men, the benefits would, however, be at least equal to the minimum wage.
} 
NETHERLANDS

Exchange and Interest Rate Developments, 1982-1997 (In Percent)
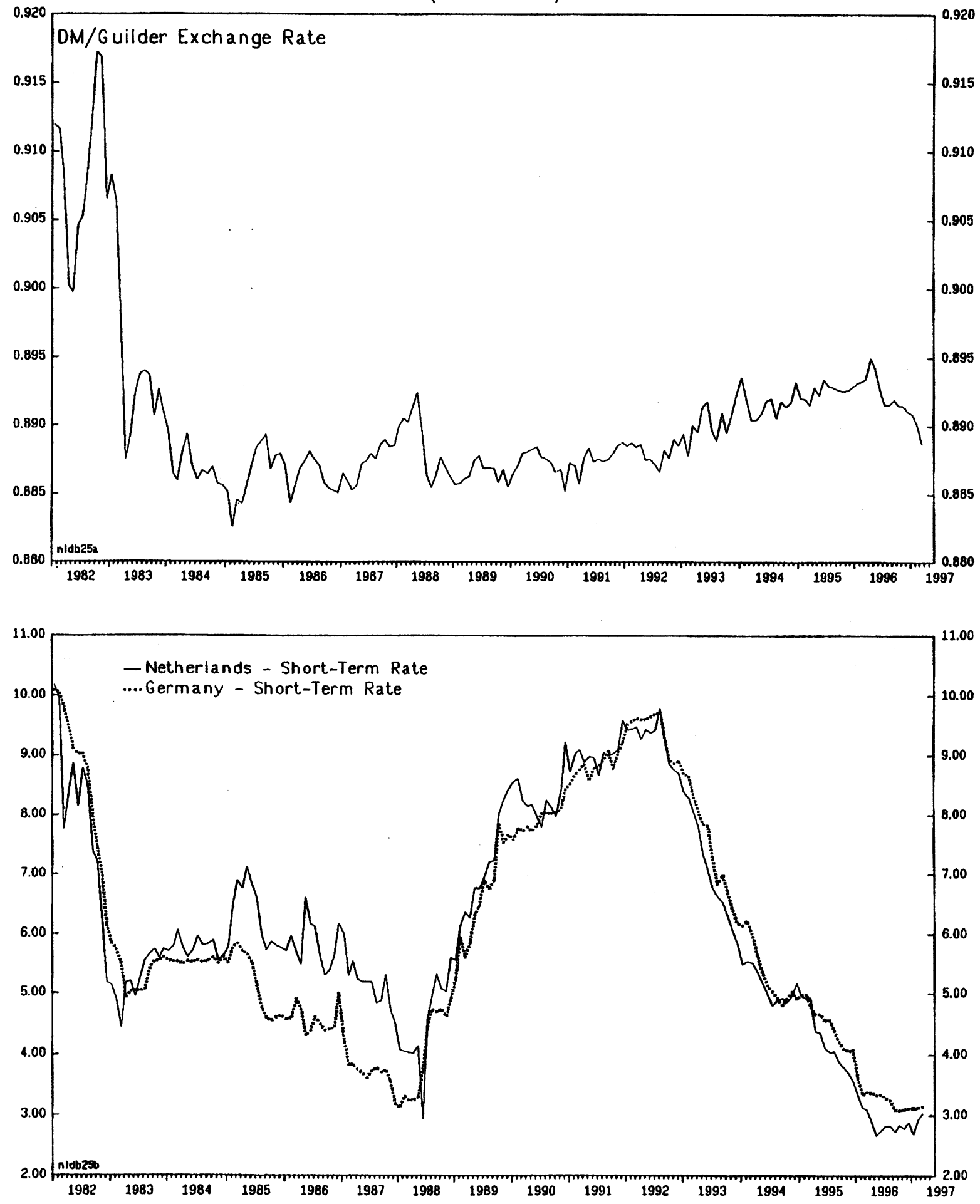

Source: IMF, International Financial Statistics. 
CHART 11

NETHERLANDS

\section{External Indicators}

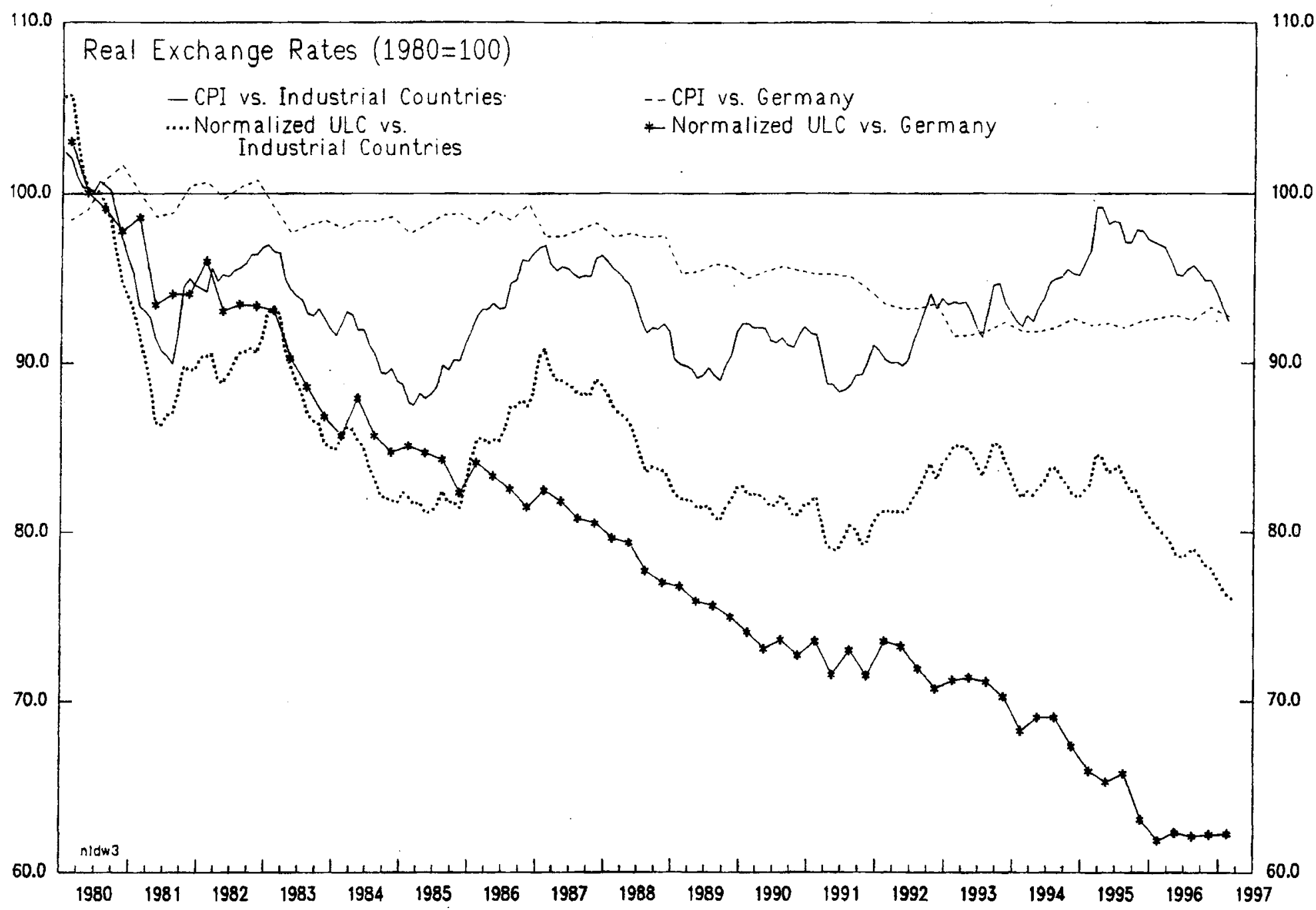

Source: IMF, International Financial Statistics. 
worker would be eligible for welfare. Unemployed workers who were at least 58 years old at the time they received WWV-benefits, would retain them until age 65 .

- In 1986, unemployment benefits were reduced to 70 percent of the last-earned wage. 8

- In 1987, both forms of unemployment insurance were merged into a new, premiumfinanced, unemployment insurance. While benefits remained at 70 percent of the lastearned wage, the duration for younger workers was shortened, and eligibility was tightened. A person who had worked at least 26 weeks during the year preceding unemployment would be eligible for half a year of unemployment benefits. To receive benefits during a longer period, that person now also needed to have worked for at least four out of the last five years. A worker who had worked at least four out of five years would, if he was below age 23, receive six months of unemployment benefits; and from age 23 to age 28 , nine months of benefits; if above age 58, six years of benefits; and an increasing duration of benefits applied between ages 28 and 58 .

As regards disability benefits:

- Before January 1985, benefits for persons who were more than 80 percent incapacitated were set at 80 percent of the last-earned wage (up to a maximum), while for persons with lesser degrees of disability, partial benefits were paid. Benefits lasted until age 65 . The degree of disability was determined by calculating the ratio of the salary a disabled person would be able to earn after and before his disability. However, if a person was partially disabled, but was unable to find a job, it was assumed he was unemployed because of his disability, and therefore he would receive full benefits.

- In 1985, two changes took place. First, benefits were reduced from 80 percent to 70 percent. Second, if a partially disabled person could not find a job, that person would no longer receive full disability benefits; instead his partial disability benefits were supplemented by unemployment benefits-which taper off after a few years.

- In August 1993, benefits were reduced further. Benefits for new disability claimants were reduced sharply (the existing disabled were grandfathered). ${ }^{9}$ The reduction involved limiting the duration of full benefits -70 percent of the last-earned gross

'(...continued)

Married women were not eligible for the budget-financed unemployment benefits. When women became eligible as well, in 1985, benefits were reduced from 75 percent to 70 percent.

${ }^{8}$ WWV-benefits had already been reduced to 70 percent in 1985.

${ }^{9} \mathrm{Many}$ firms took up additional insurance to compensate for the reduction in benefits under the official disability scheme. Thus, for most workers, the reduction in insured benefits was less than suggested by the reforms. 
wage- to no more than six years (six months for disabled above age 32, six years for those above 58, with increasing duration in between) while a lower entitlement was paid subsequently, depending on the age at which the scheme was entered and the salary previously earned. ${ }^{10}$

- Apart from the reduction in benefits, eligibility was tightened as well. In calculating disability, the reference point became ability to perform any paid job, regardless of previous training or work experience. As the range of alternative employment considered was widened, claimants could now be found to have a lower degree of disability. Moreover, existing beneficiaries under the age of 50 would be re-examined.

As regards sick leave:

- Benefits were reduced in various steps from 100 to 70 percent of wages."

- From the beginning of 1994 onwards, sickness benefits were only paid out by a collective insurance after the first six weeks of sickness. Firms were made legally responsible for payment of salary equal to a least 70 percent of salary during the first six weeks of sickness.

- In 1996, the collective insurance was abolished altogether, and firms were made legally responsible for sickness payments during the first year of sickness (after the first year, disability benefits become applicable).

\section{F. Labor Market Measures}

40. Labor market measures focused both on reducing wage costs, and on improving supply-side incentives, especially for younger people.

41. First, the nominal minimum wage for adults was frozen during most of the $1980 \mathrm{~s}$ and a large part of the 1990 s. In 1984, the minimum wage was reduced by 3 percent; subsequently it was frozen until 1990, and then again from 1993 until 1996. As a result, the gross real minimum wage declined substantially, and by 1996 was 22 percent lower than it was in 1979

\footnotetext{
${ }^{10}$ Reduced benefits rise with the age (A) at which the scheme is entered. The benefit is equal to the minimum social benefit, or 70 percent of the minimum gross wage $(M)$, and a supplement that depends on A and the last-earned gross wage (W). Specifically, the benefit is determined as $0.7 \mathrm{M}+0.14(\mathrm{~A}-15)(\mathrm{W}-\mathrm{M})$. Thus, a worker of age 40 , with a wage equal to 130 percent of the minimum wage would receive a benefit equal to 61.9 percent of his last earned wage.

${ }^{11}$ In many cases, after the reductions, a supplement was paid by employers to top up sick leave to 100 percent of wages.
} 
(Chart 12). Youth minimum wages were twice cut substantially (at the beginning of 1981 and mid-1983, Table 1), and at other times followed the nominal freeze of the minimum wage for adults. For ages 15 to age 19, the youth minimum wage was lowered by a cumulative 25 percent to 30 percent, and by somewhat less for ages 20 to 22 . Thus, real youth minimum wages declined very substantially; the real minimum wage for an 18-year old, for instance, declined by 43 percent over the 1979-1996 period.

42. Second, because of its link to the minimum wage the gross minimum social benefit declined in real terms by more than 20 percent (and the net minimum benefit by some 12 percent), thus strengthening incentives in the labor market (Chart 12).

Table 1. Netherlands: Youth Minimum

Wages

(In percent of adult minimum wage)

\begin{tabular}{cccc}
\hline Age & $\begin{array}{c}\text { Until } \\
\text { end-1980 }\end{array}$ & $\begin{array}{c}\text { Beginning } \\
1981\end{array}$ & $\begin{array}{c}\text { Beginning } \\
\text { mid-1983 }\end{array}$ \\
\hline 22 & 92.5 & 90.0 & 85.0 \\
21 & 85.0 & 80.0 & 72.5 \\
20 & 77.5 & 70.0 & 61.5 \\
19 & 70.0 & 60.0 & 52.5 \\
18 & 62.5 & 52.5 & 45.5 \\
17 & 55.0 & 45.0 & 39.5 \\
16 & 47.5 & 40.0 & 34.5 \\
15 & 40.0 & 35.0 & 30.0 \\
& & & \\
\hline
\end{tabular}

43. Third, partly with a view to encouraging wage moderation, taxes and premiums paid by employees were cut substantially. The reduction of taxes and premiums allowed for an increase in disposable income even in the absence of real gross wage increases, thereby reducing wage demands. The impact of cuts in taxes and premiums was quite substantial: whereas the real gross wage of the average production worker declined by 1.1 percent over the 1983-1996 period, the corresponding real net wage went up by 11.6 percent (Chart 12).

44. From the early 1990 s onwards, various measures were taken to cut non-wage labor costs, especially at the lower end of the wage spectrum. As a result, the tax wedge for lowskilled workers declined substantially (Chart 13). Two broad schemes are now in effect to cut non-wage labor costs for the low-skilled and the long-term unemployed. For workers hired at close to the minimum wage there is a reduction of close to 30 percent in social security contributions, which cuts employment costs by some 5 percent. This scheme works together with similar, larger cuts in the case of long-term unemployed (those out of work for more than 

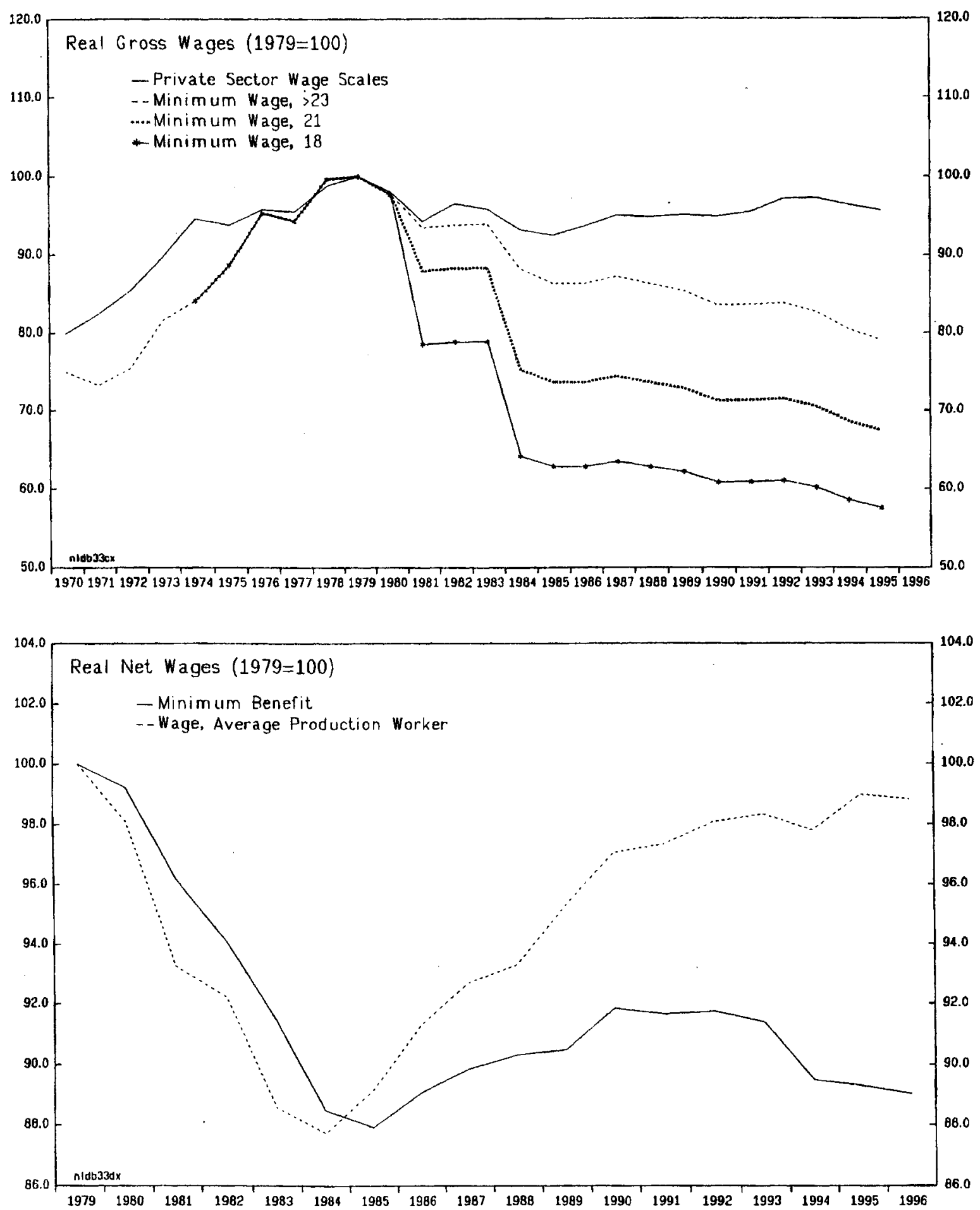

Sources: OECD, Economic Outlaok; Central Planning Bureau; and staff calculations. 
CHART 13

NETHERLANDS

\section{Average Wedge Private Sector Workers}

(In Percent)

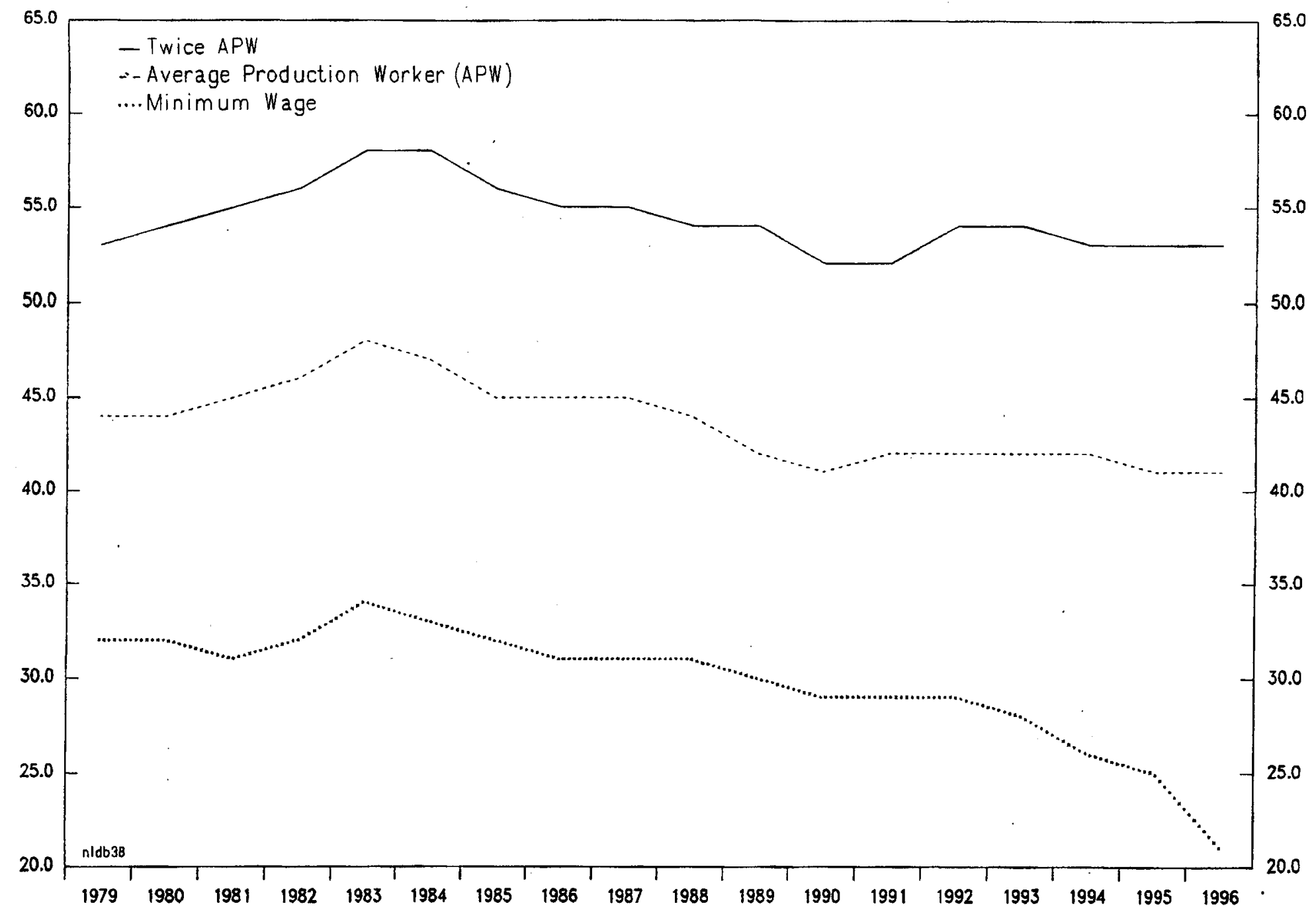

Source: Central Planning Bureau, Central Economic Plan. 
a year); and for workers meeting both criteria, virtually no contributions are payable, reducing labor costs for those workers by about 17 percent.

45. The process of eligibility tightening and duration shortening in the case of unemployment and disability benefits, which was described above, also strengthened supplyside incentives, especially for younger workers. The crucial clements appear to have been the cut in unemployment benefit duration for workers below 23 from $2 \frac{1}{2}$ years to 6 months, with smaller but still substantial cuts for older workers; and the reduction in benefits from 80 percent to 70 percent of the last earned wage. By contrast, the similar measures taken.for disability benefits likely were far less effective, as in many cases additional insurances was taken up by firms.

46. No measures were taken to stimulate part-time work; indeed at times it was made somewhat less attractive for employers to hire part-time workers. For instance, in 1992, the minimum wage, which so far had applied only to workers employed at least one-third of fulltime, was extended to all workers.

47. One negative influence on the supply-side of the labor market, however, was that participation of the elderly was reduced by government policy. From 1984 onwards, the unemployed aged $571 / 2$ and older were no longer required to look for a job, thus opening a substantial gap between registered unemployment and unemployment benefits recipients.

\section{G. Product Market Measures}

48. Product market reforms have moved to center stage only since the early 1990s, but have since been implemented in a wide range of areas: anti-cartel measures, regulatory changes to enhance competition, and the introduction of market forces in (heretofore) semipublic sectors (SM/96/118).

49. Anti-cartel measures consisted of the general prohibition of price fixing from July 1993, and of market sharing and collusive tendering from June 1994. This was done on the basis of existing law-which allowed cartels unless they were specifically prohibited. A new Competition Law was passed in early 1997; this is based on the prohibition principle, similar to that used by the EU, and includes merger control procedures.

50. Regulatory changes have included the liberalizing of business licensing requirements and the extension of shop opening hours. Licensing requirements were liberalized in 1996; previously, Dutch business licensing requirements were comprehensive and stringent, specifying substantial education and training in sectors such as construction, retail trade, and various services. Shop opening hours were extended significantly in 1996. Previously, shops were not allowed to be open after 6 p.m., or on Sundays. In 1996, shops were allowed to remain open until 10 p.m. and up to 12 times a year on Sunday, while municipalities may decide to allow night and additional Sunday openings. 
51. Market forces were introduced in various public service areas. The postal and telephone services company was privatized in 1994-95, and is facing increasing competition from newly licensed operators in specific fields. Competition in regional bus services, which until recently were firmly lodged in the public sector, was increased through competitive bidding for routes. New providers of rail transport are being allowed, while preparations are under way to privatize the national railroad company.

52. In sum, the policy reforms initiated in the 1980 s and early 1990 s have been comprehensive and sustained. Critically, the impact of reforms in various areas-monetary, fiscal, and labor market, in particular-has been mutually reinforcing. The linkage and positive interaction of these reforms is discussed in Box 3. Over the same period, there has been a marked turnaround in economic performance, and this is reviewed in the following section.

\section{ECONOMIC RECOVERY SINCE THE EARLY 1980S 12}

\section{A. Introduction}

53. Since the early 1980 s the performance of the Dutch economy has improved substantially. Economic growth has increased in comparison with that in neighboring countries; inflation has been low; long-term interest rates have become the lowest in the EU; employment growth has been strong; and participation in the labor force has increased.

\section{B. Economic Growth}

54. The growth of GDP per capita, which was well below the EU-average in the early 1980s, has since the late 1980s been above it (Chart 14), and the economy suffered less from the recessions in 1992-93 and 1995 than other European economies. An important reason for the improvement in economic performance appears to have been the recovery of profitability in firms, which by the late 1980 s had returned to the level of the early 1970s. This recovery of profitability, which was associated with the impact of wage moderation, led to a strong increase of both corporate saving and investment. ${ }^{13}$

55. During the mid-1980s, growth was mainly based on exports and investment, while consumption growth was slow. In 1988, private consumption was only 10 percent higher than in 1980, while private fixed investment was 45 percent higher. Both the slow growth of consumption and the rapid growth of investment (Chart 15) were associated with a substantial decline in the share of labor income in the value added of firms.

\footnotetext{
${ }^{12}$ Prepared by Bas Bakker.

${ }^{13}$ Although both corporate saving and investment increased, investment increased by less than saving. For a discussion of the factors underlying this asymmetric behavior see SM/95/70.
} 


\section{Box 3. Interlinkage of Structural Reforms in the Netherlands}

Since the early 1980s, the Netherlands has embarked on an extensive set of reforms, the various elements of which were mutually re-inforcing:

- Wage moderation was in large part the result of a consensus between unions and employers on its beneficial effects for job creation; against the background of the disastrous economic situation of the early 1980 s, and in a setting that included a credible exchange rate anchor. It was widely recognized to be needed both to rebuild the profitability of firms and to avoid a further substitution of capital for labor. Wage moderation was underpinned by rapid labor force growth (which reflected a sharp increase in the participation rate of women as well as demographic growth in the labor force) and by several of the structural measures listed below.

Cuts in taxes and social security premiums paid by employees allowed disposable incomes to rise even in the absence of significant wage increases. In the 1970s, sharp increases in taxes and premiums had been shifted to wages: it was expected that by lowering taxes and premiums, wage demands would be mitigated.

Cuts in social security premiums paid by employers helped to stimulate demand for labor.

The cuts in taxes and social security premiums were made possible by fiscal consolidation. Containing primary expenditure allowed a gradual reduction of taxes and premiums, while at the same time reducing the deficit.

A reduction of unemployment and disability benefits from 80 percent to 70 percent of wages, and a freezing of other social security benefits in nominal terms, contributed to expenditure restraint and also helped ease supply-side constraints in the labor market.

- In recent years, labor supply was increased by structural reforms of disability and sick leave: the inflow into disability was reduced by tightening of eligibility criteria, while the outflow was raised by a re-examination of current recipients; sick leave payments were shifted from a collective insurance to employers, thus creating an incentive to reduce sick leave.

Wage moderation was aided by a freeze of the nominal minimum wage (and the related freeze of the nominal minimum benefit), which also aimed to increase wage dispersion; as a result, the difference between the average wage and the minimum wage increased by some 15 percentage points, although effective dispersion does not appear to have increased commensurately.

Youth unemployment was addressed by substantial cuts in youth minimum wages: twice, these were cut substantially; at other times they followed the freeze in the regular minimum wage. 


\section{$-38-$ \\ CHART 14 \\ NETHERLANDS}

\section{International Comparisons: GDP Per Capita, 1982-1996}

$(1982=100)$
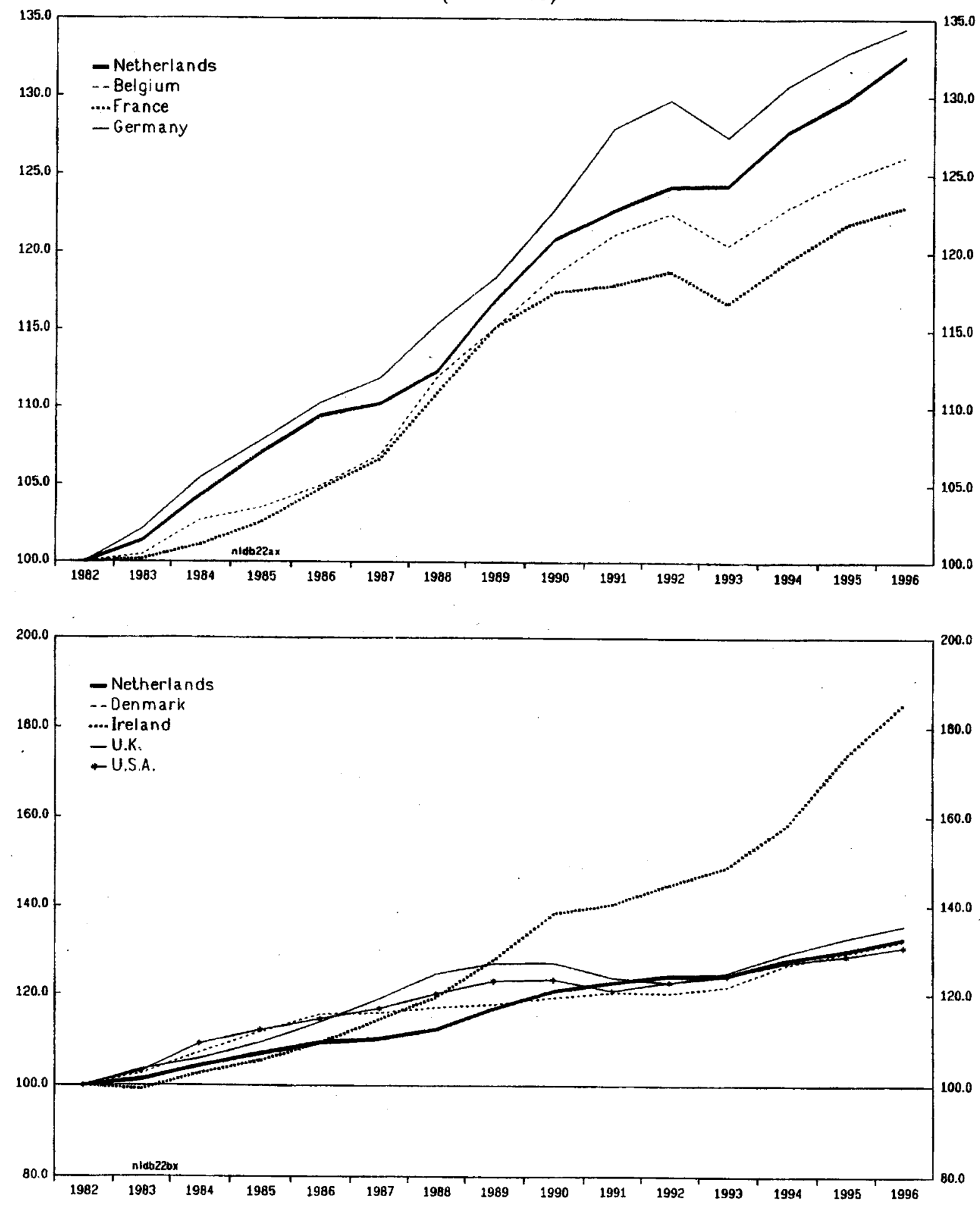

Source: IMF, World Economic Outlook. 
NETHERLANDS

\section{Real Private Consumption and Private Investment, 1982-1996}
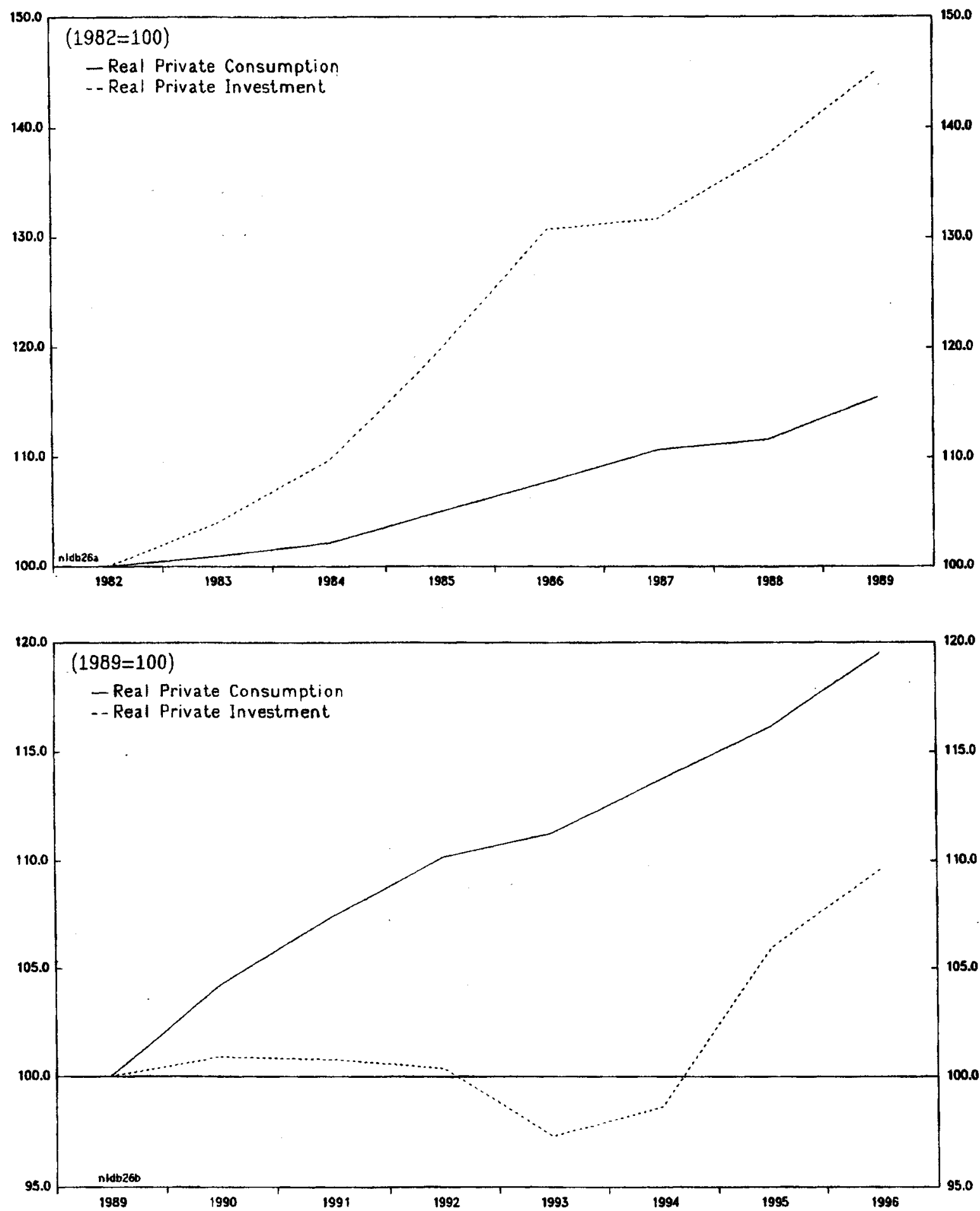

Source: OECD, Economic Outlook. 
56. Since the late 1980s, economic growth has become more balanced, with consumption an important contributor to growth. Indeed, the rise in consumption has been stronger than in many other European countries, in spite of very moderate increases in real wages. Strong consumption appears in part to have reflected a virtuous circle of rapid employment creation and strengthening consumer confidence. Although real wages did not increase strongly, this was to a large extent compensated for by a rapid increase in employment, and by a reduced fear of becoming unemployed-a significant factor in restraining consumer confidence in some other European countries.

57. The increase in housing prices, however, may also have played a role in sustaining consumption. Following a steep decline after 1978, real house prices started to edge up from the mid-1980s onward, and increased strongly in the early 1990s (Chart 16). Several factors may have lain behind the recent increase in housing prices. First, the low level of long-term interest rates made it possible to finance substantially more expensive houses than in the early 1980s. Second, in 1993 there was a change in the calculation of borrowing limits, as both incomes in a dual income household were now included fully in banks' credit assessments for mortgages. Third, rent increases in the 1980s and 1990s were well above inflation, which made the purchasing of houses more attractive. The sizeable rise in house prices in the 1990s was associated with a rapid increase in mortgage borrowing, which in part was used to finance consumption (Chart 16).

58. As regards the sectoral pattern of output growth, since 1982 the sheltered sector has expanded more strongly than the exposed sector, whereas in the 1970s both sectors had grown at the same rate. While the reasons for this shift in performance are not entirely clear, an important factor may have been the lower pace of wage growth. As the sheltered sector is much labor intensive than the exposed sector, rapid wage increases will lead to an increase of the relative price of non-tradables, thereby discouraging output growth in this sector (Chart 17). A slowdown of wage growth can thus be expected to have a stronger positive impact on the sheltered than on the exposed sector (see SM/96/118).

59. Overall, GDP growth since the early 1980 s has been much more labor-intensive than before, and labor productivity increases have been very low (Chart 18). Several factors may have lain behind the decline in productivity growth. First, in the 1970s there may have been excessive substitution of capital for labor; with the decline in wage growth, this excessive substitution came to a halt. Second, in the 1980s a large number of jobs was created at the lower end of the wage spectrum: a rapid increase in jobs at the lower end will depress aggregate labor productivity growth, even when the productivity growth of the various individual workers does not change. Third, as noted above, output growth was most pronounced in the sheltered sector (i.e., services), which has far lower productivity increases than the open sector. A related consideration is that the pace of human capital acquisition may have been lower in some of the jobs created during this period. Finally, the rapid pace of increase in total factor productivity in the 1970s may in some respects have reflected unusually strong incentives to maximize the efficiency of the production process in the presence of very high real wages. 
Housing Market Developments, 1970-1996
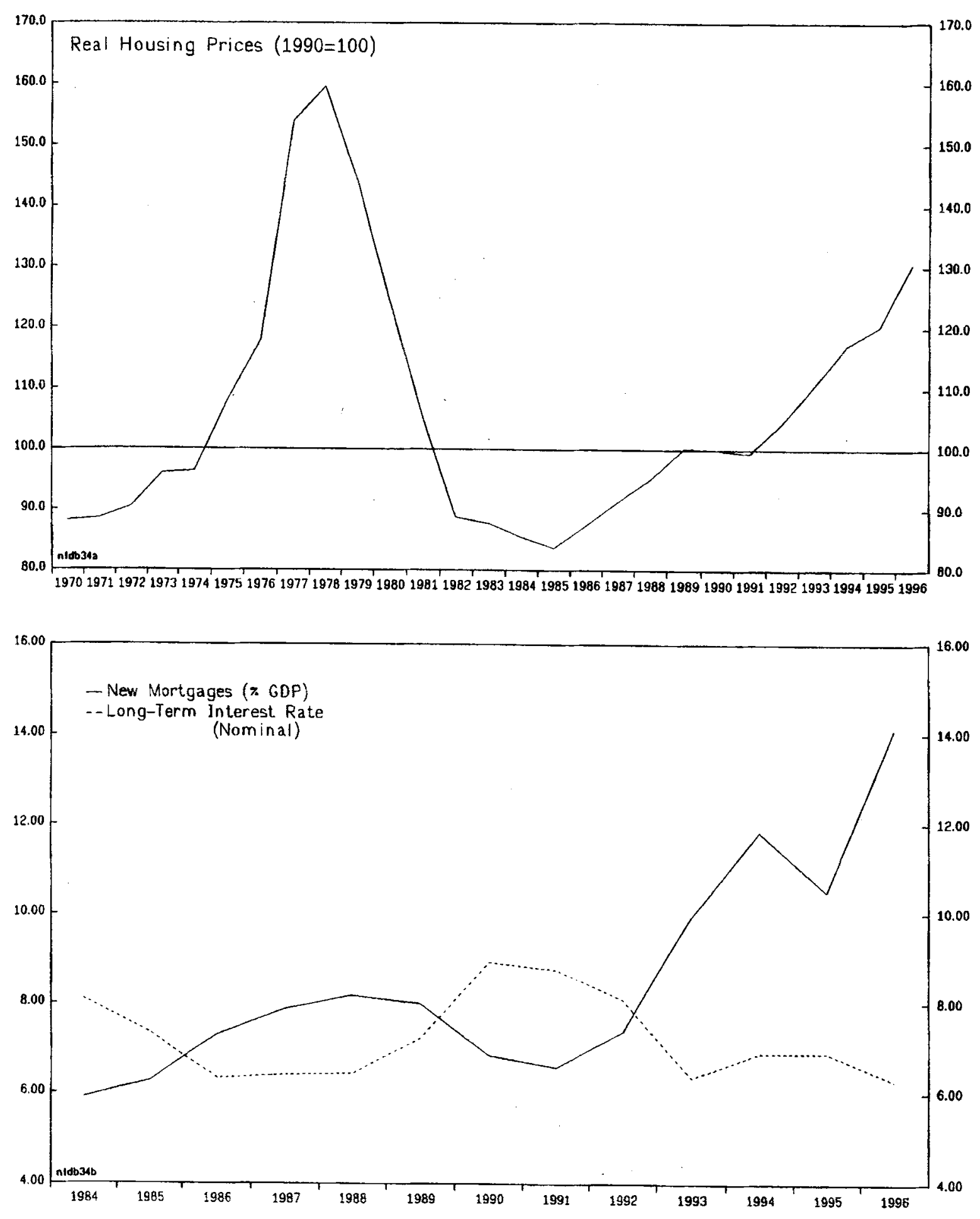

Sources: De Nederlandsche Bank; Central Bureau of Statistics; and staff calculations. 
CHART 17

NETHERLANDS

Volume of Value Added in Exposed and Sheltered Sectors

$(1970=100)$

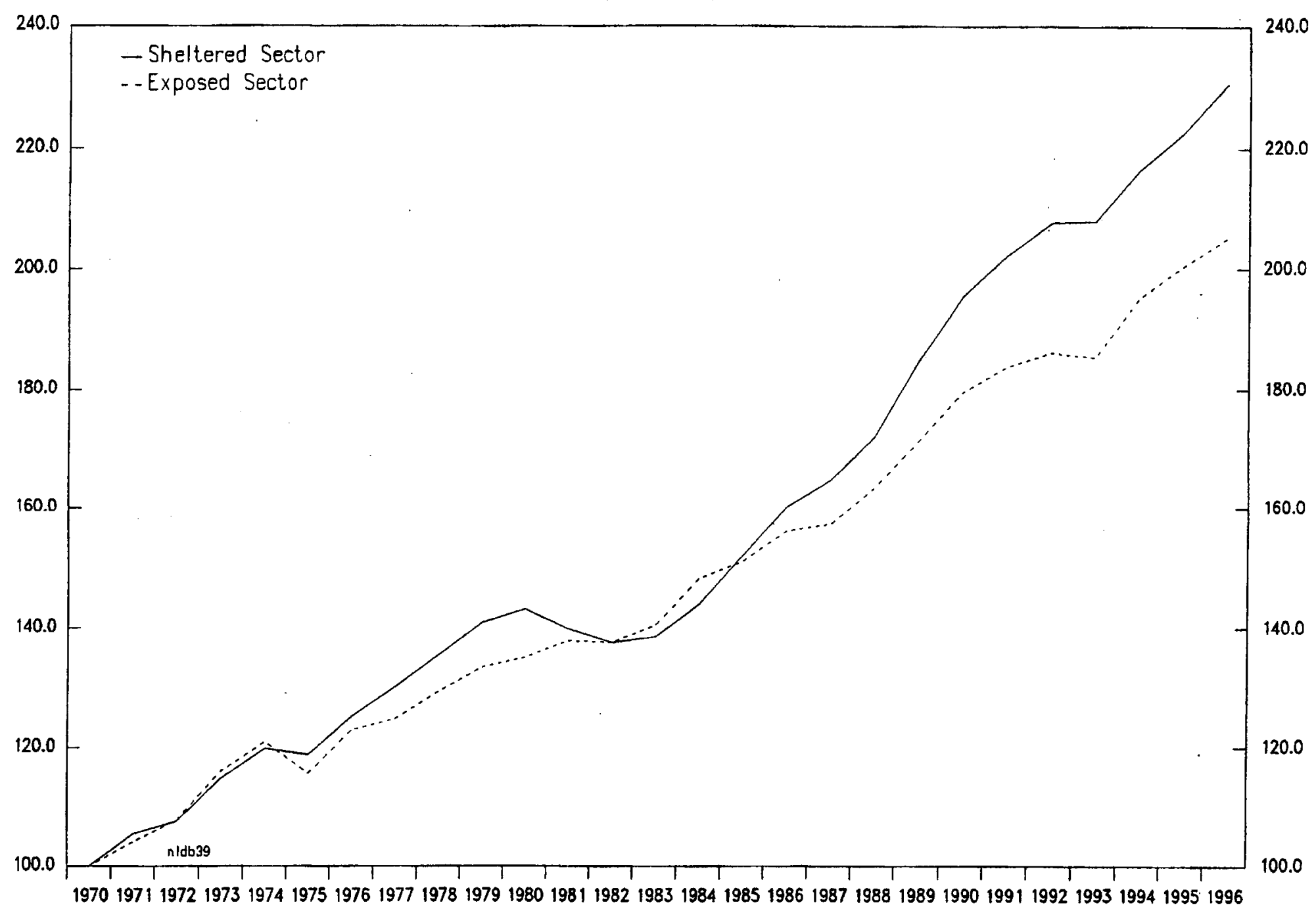

Source: Data provided by the Central Planning Bureau. 
CHART 18

NETHERLANDS

Labor Productivity Growth

(In Percent)
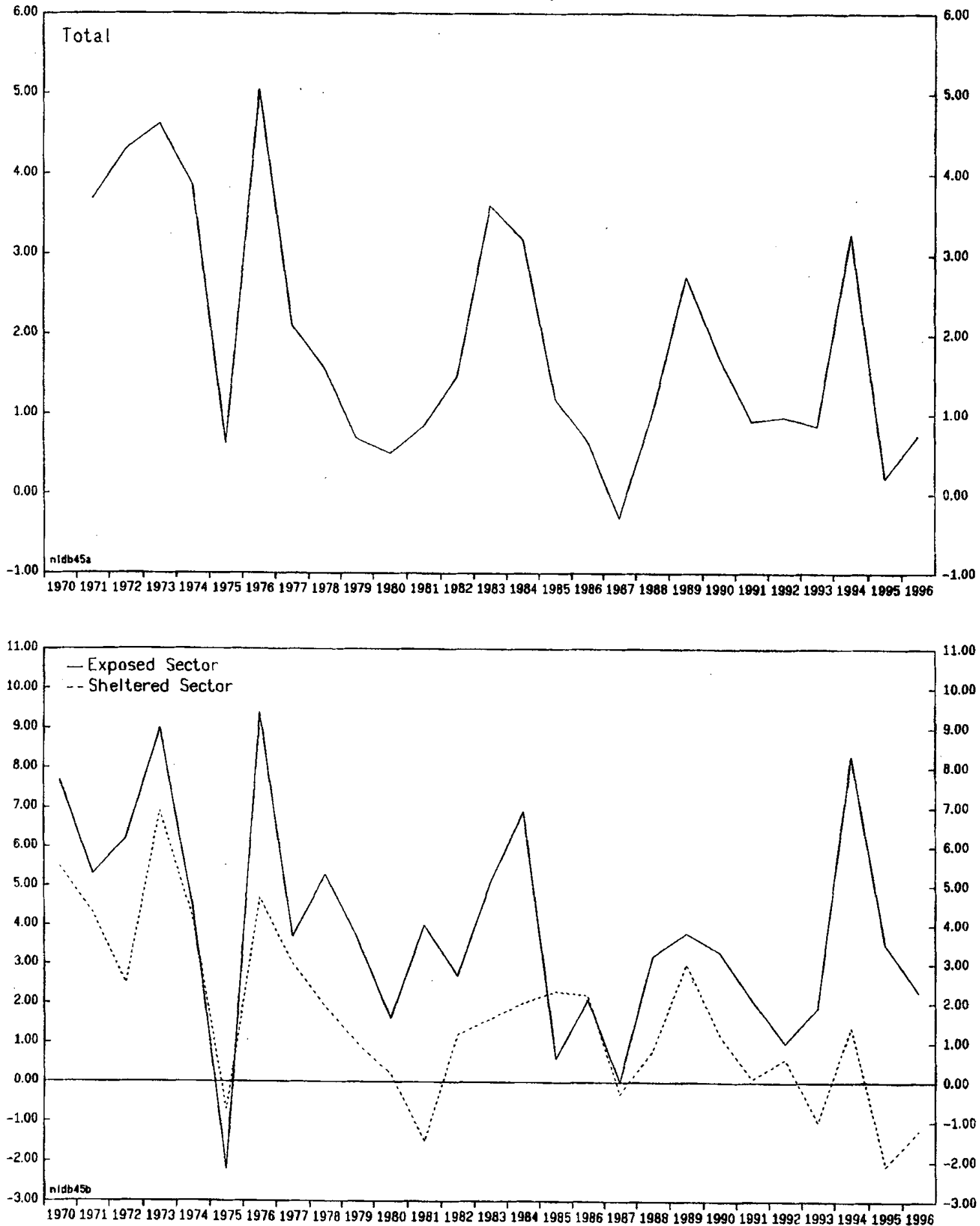

Source: Data provided by the Central Planning Bureau. 
60. The lower labor productivity growth was not reflected in lower GDP growth. Whereas in the 1970s high labor productivity growth was associated with a poor output growth performance, the decline in labor productivity growth has been associated with a better growth performance. Moreover, with more employment generated for the same output growth, there were fewer new social benefits recipients, contributing to a decline in the collective burden of taxes and premiums. The rise in employment benefited the public finances.

61. It might be suggested that the Netherlands switched from a European growth pattern (high productivity growth, but low employment growth) to a pattern more similar to that in the United States (lower productivity growth, albeit at a high level of productivity, but high employment growth). However, the very marked nature of this pattern in recent years may well, in part, reflect the transition from a production process in which labor had become very expensive to one more closely aligned to that in other comparable economies.

\section{Prices, Interest Rates and the Exchange Rate}

62. Since the early 1980 s, the rate of inflation in the Netherlands has been among the lowest in the world, and in many years below that even in Germany. Such very low inflation was a new phenomenon, as in the 1960s and 1970s, inflation was well above that in Germany-although still not high by European standards.

63. First, in terms of the overall policy framework, low inflation was clearly aided by the tight and increasingly credible link to the deutsche mark. As noted above, the guilder-deutsche mark parity has remained unchanged since 1983. The low inflation in turn made the link more credible; and the guilder did not come under attack in the EMS-crises of 1992 and 1993 . As noted above, this contrasted with developments in the 1970s, when the Dutch inflation rate was well above German inflation, and the exchange rate link was at times subject to speculative attacks.

64. An important factor behind the low inflation has been the very modest increase in unit labor costs. From 1983 until 1990, unit labor cost increases never contributed more than 0.4 percentage points to inflation, as measured by the price index of consumer goods. Inflation during this period was mainly the result of increases in import prices, administered prices, and a widening of profit margins of firms.

65. The difference in wages was even more pronounced than the difference in unit labor costs, as in many other countries higher wage growth was compensated by more pronounced labor shedding. In many other European countries, firms reacted to rapid wage growth by substituting capital for labor, and by restructuring their firms in order to shed labor; as a result of this, labor productivity grew faster in countries with more rapid wage increases.

66. The competitive position of the economy, as measured by the real exchange rate, did not change greatly in the past decade, as a better performance in nominal unit labor costs was 
compensated by an appreciation of the guilder. However, the real exchange rate vis-à-vis Germany depreciated quite significantly, as no exchange rate alignment took place vis-à-vis the deutsche mark, while nominal unit labor costs grew substantially more slowly.

67. The excellent price performance led to the disappearance of the inflation differential with Germany, and, subsequently, in conjunction with exchange rate limit, to the lowest longterm interest rates in the EU. As no exchange rate devaluations took place after 1983, the risk premium on Dutch interest rates, vis-à-vis German rates, gradually disappeared. Moreover, the gradual improvement in economic performance, the low inflation, and the various reforms that were introduced are likely to have improved investors' perspective on the outlook of the economy, thereby increasing the attractiveness of Dutch bonds.

\section{Labor Market}

68. Employment has grown rapidly since 1984; indeed, in terms of persons, the rate of increase was similar to that in the United States (Chart 19). ${ }^{14}$ This experience thus differs strikingly from that in many other European countries, where there was only very modest employment growth. The difference with other European countries became especially pronounced in the 1990s, when many other countries experienced a decline in employment, while in the Netherlands employment continued its upward trend. Employment growth in fulltime equivalents was less strong than in persons. The incidence of part-time employment in the Netherlands is high and increasing: more than one in three employees in the Netherlands works part-time, far more than elsewhere in Europe. However, even in full-time equivalents employment grew rapidly, by 19 percent over the $1982-1996$ period. ${ }^{15}$ Survey data suggests that part-time work generally corresponds to the preference of employees.

69. Employment growth was solely the result of job creation in the private sector, as government employment decreased. Employment in the private sector increased by 21 percent over the same 14 years, while employment in the government sector decreased by 7 percent. These developments are very different from those in the 1970s, when private sector employment declined, and government employment went up by a quarter (Chart 20). Within the private sector, employment creation was concentrated in the sheltered sector, but at the same time the sizable decline in employment that previously took place in the exposed sector came to an end. As noted above, during the 1970-1982 period, output in the sheltered and the

\footnotetext{
${ }^{14}$ The labor market data in Chart 18 differ slightly from those in the other charts. In Chart 18 OECD data are used, whereas in the other charts national data are used

${ }^{15}$ The amount of hours associated with a full-time equivalent has decreased slightly over the past decade, but much less so than in countries like Germany and France. Indeed, in Germany, the average "full-time" working week decreased so strongly that the average number of hours per worker (i.e., including part-time workers) declined by more in Germany than in the Netherlands, despite the higher incidence of part-time work in the Netherlands.
} 


\section{Labor Market Indicators, 1980-1997}
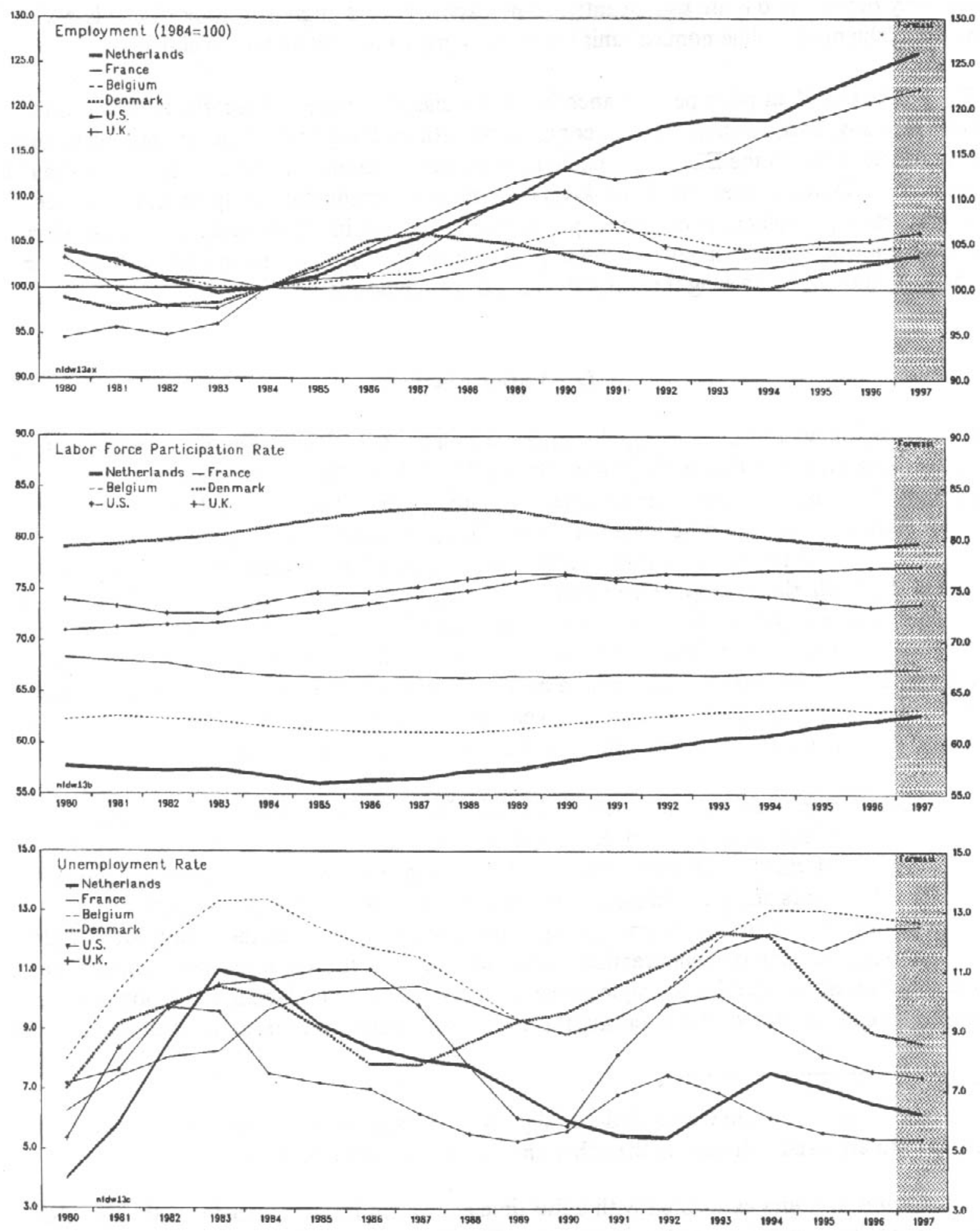

Source: OECD, Economic Outlook 
CHART 20

NETHERLANDS

Employment, 1982-1996

(In Full-Time Equivalents, 1982=100)

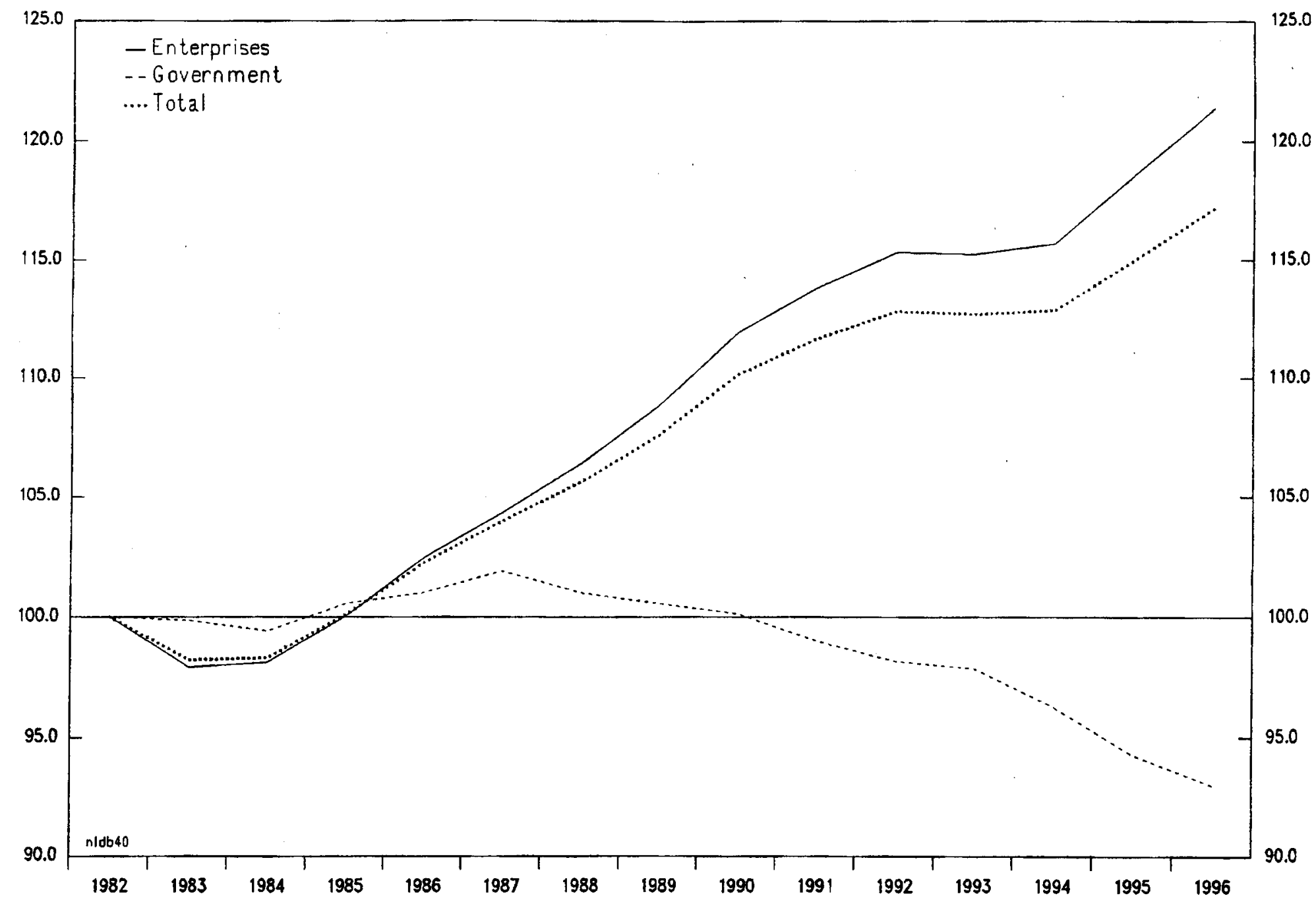

Source: Data provided by the Central Planning Bureau. 
exposed sector grew at virtually the same rate, but in the 1982-1996 period output in the sheltered sector grew substantially faster, suggesting that the rapid employment creation that has been experienced in the Netherlands was not solely the result of an improvement in competitiveness (Chart 21).

70. Labor supply also grew rapidly in this period, fueled by an increase in the participation rate of women, natural population growth, and immigration (Chart 22); it was also encouraged, no doubt, by rapid employment growth. The participation rate of women increased strongly, while that of men did not change much.

71. As a result of rapid employment creation, official unemployment dropped significantly, especially among the youth. The OECD-standardized unemployment rate dropped from 11.0 percent in 1983 , to 5.4 percent in 1992 , while youth unemployment declined from 24.9 percent to 7.8 percent. In 1993 and 1994, as a result of the economic downturn, unemployment went up, but since 1995, it has resumed its downward trend. The number of unemployment benefit recipients declined less; and the gap between official unemployment and unemployment benefits recipients widened progressively. By 1996 the unemployment rate was 4 percentage points lower than the unemployment benefits recipients rate, ${ }^{16}$ and only slightly below its level in the early 1980s (Chart 23). An important reason behind the large difference between registered unemployment and the number of unemployment benefit recipients is absence of job search requirements for unemployed persons aged over 58 .

72. The underlying level of non-employment declined even less, however, if the rise of the number of disability benefits recipients is taken into account. The number of disability benefits kept rising until 1994, and only thereatter declined somewhat. The percentage of the working age population that is on either unemployment or disability benefits kept rising throughout the 1980s, and reached an all-time high in 1994 (Chart 24). Thus, employment creation mainly served to absorb increased participation by women; it did not contribute very much to a reduction of the number of people in the working age population who were on benefits.

73. Finally, the improvement in the economic climate in the Netherlands during the 1980s and 1990s proved beneficial for business dynamism. Indeed, during the 1988-1993 period, the number of businesses grew by 7 percent, well in advance of the United States ( 4 percent), Germany ( 2 percent) and Japan (where there was no net increase). However, as most of these new firms were very small, their contribution to employment creation was rather limited. ${ }^{17}$ Nonetheless, with the strengthening of competition policy, and the removal of barriers to entry, this could well change in the future.

\footnotetext{
${ }^{16}$ The unemployment benefit recipients rate is defined here as number of unemployment benefit recipients/(employment + unemployment benefits recipients).
}

${ }^{17}$ Source: Ministry of Economic Affairs, Benchmarking the Netherlands, The Hague, 1995. 
CHART 21

NETHERLANDS

Employment in Exposed and Sheltered Sectors

$(1970=100)$

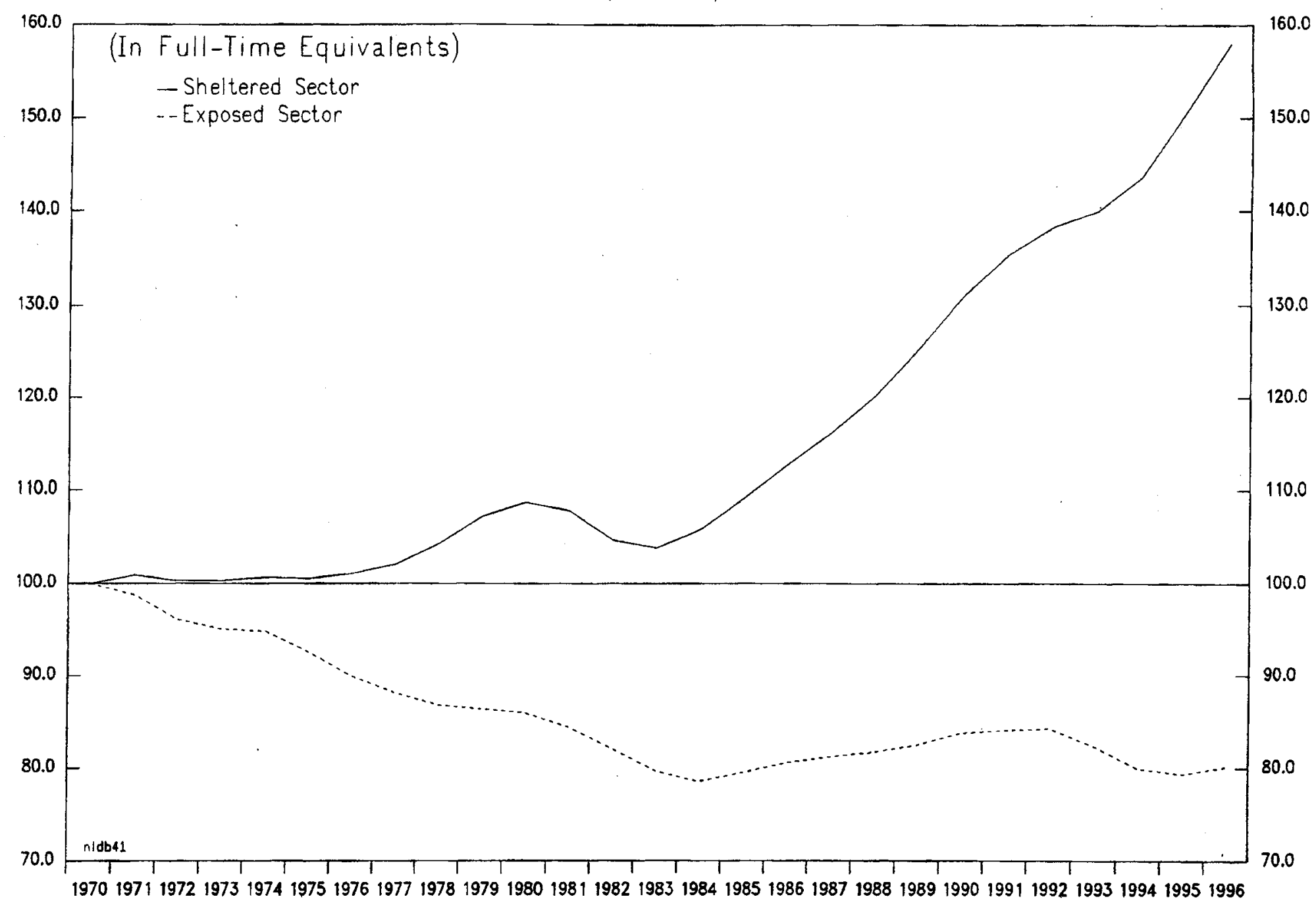

Source: Data provided by the Central Planning Bureau.

CInternational Monetary Fund. Not for Redistribution 
CHART 22

NETHERLANDS

Labor Market Indicators, 1970-1996
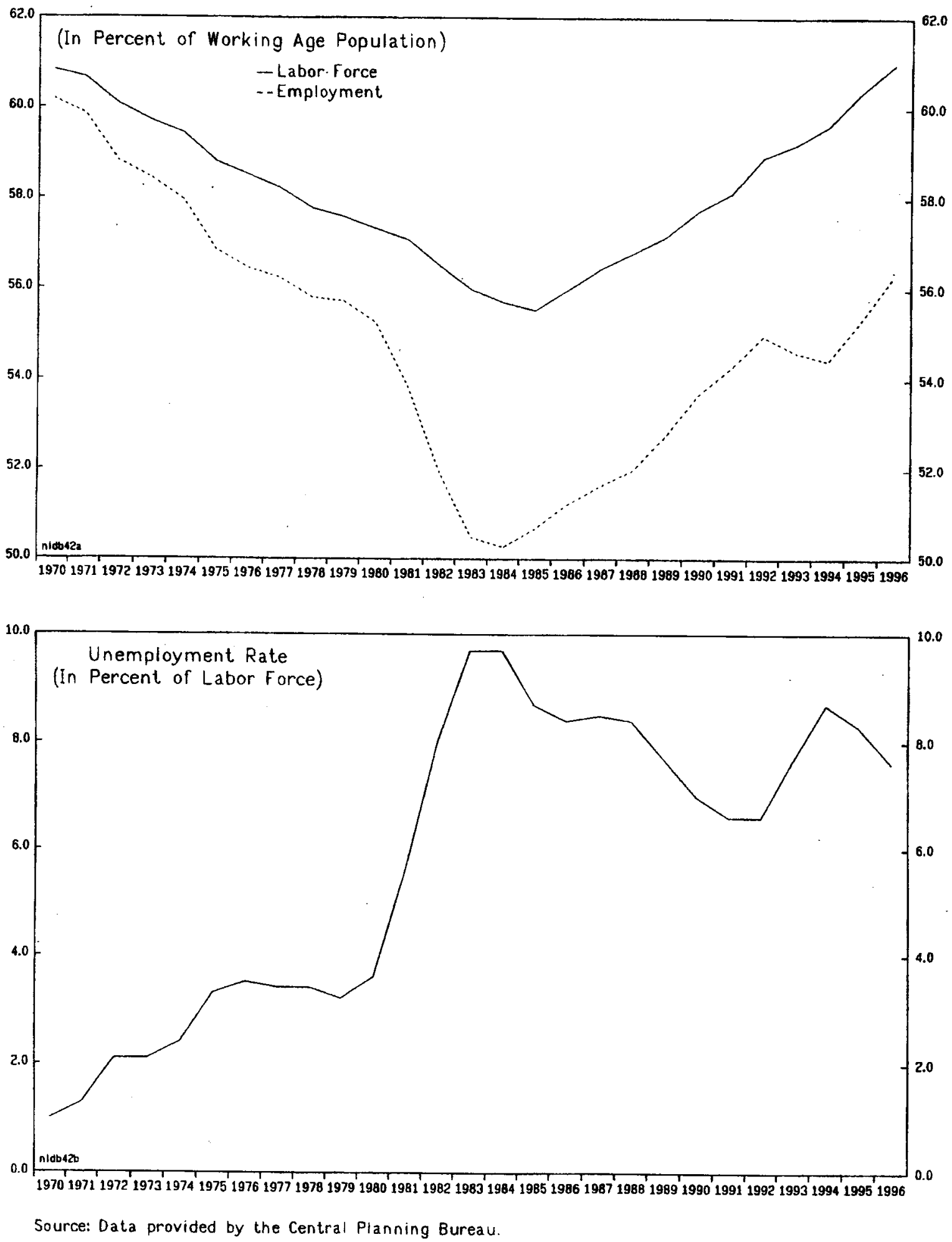

CInternational Monetary Fund. Not for Redistribution 
CHART 23

NETHERLANDS

\section{Unemployment Rate and Unemployment Benefits Recipient Rate}

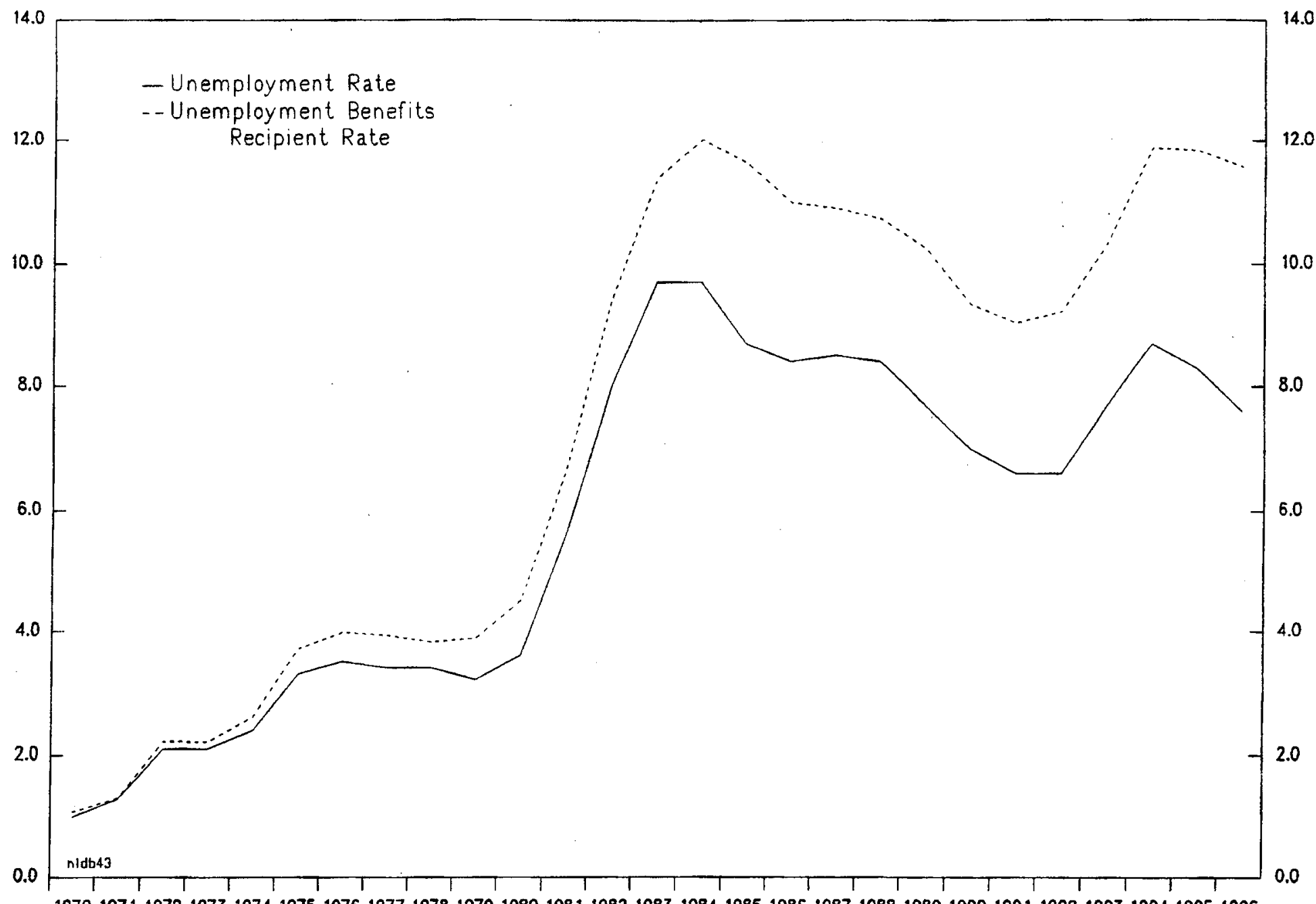

197019711972197319741975197619771978197919801981198219831984198519861987198819891990199119921993199419951996

Source: Data provided by the Central Planning Bureau.

CInternational Monetary Fund. Not for Redistribution 


\section{CHART 24 \\ NETHERLANDS \\ Unemployment and Disability Benefits Recipients \\ (In Percent of Working Age Population)}

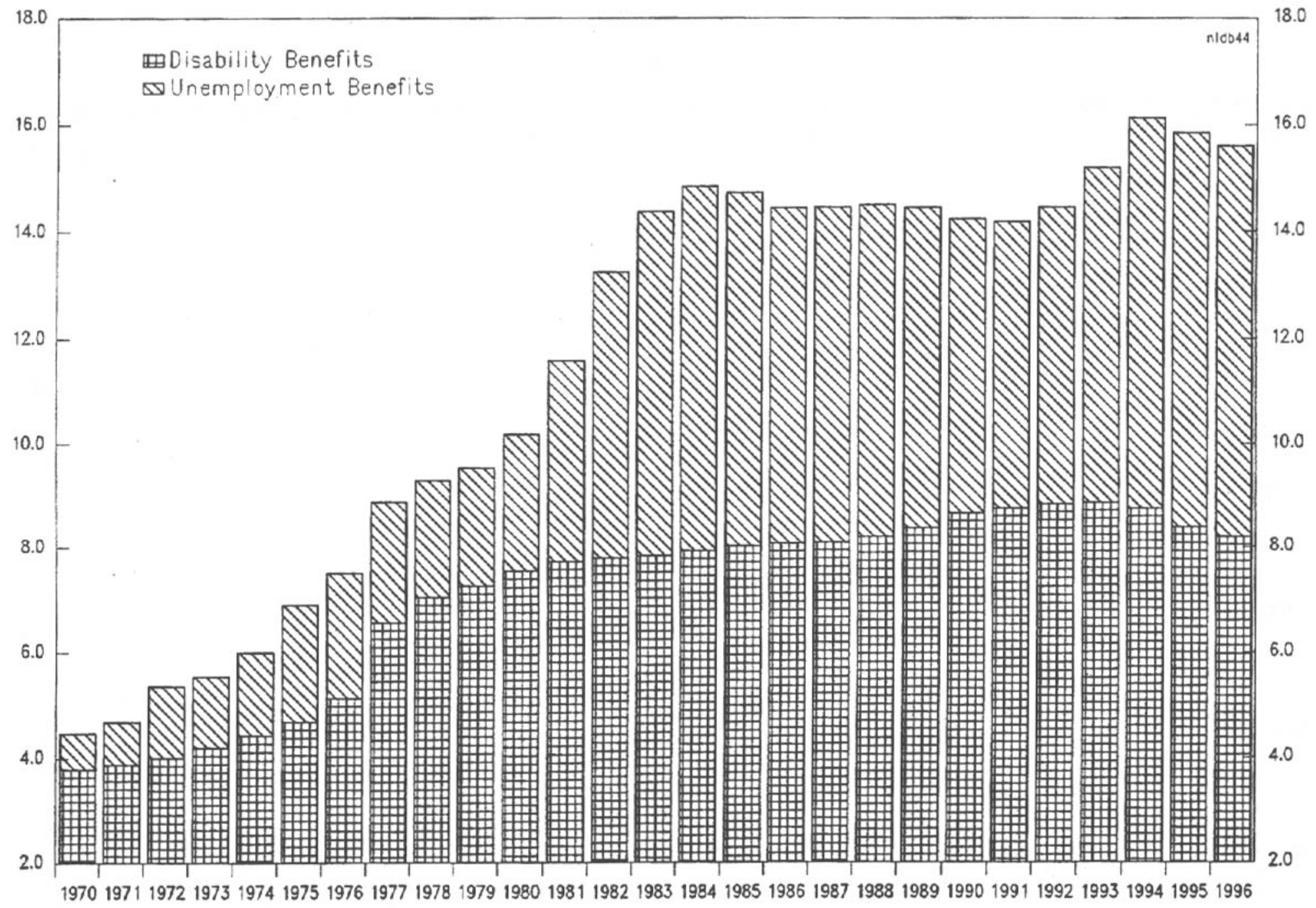

Source: Data provided by the Central Planning Bureau. 
74. Reviewing these economic developments in the period 1982-96, it is clear, intuitively, that the marked turnaround in performance was closely associated with the change in macroeconomic and structural policies, and the shift in the labor unions' approach to wage bargaining. Inspections of these parallel trends, however, leaves unresolved a number of key analytic issues concerning the underlying determinants of this improvement in performance (Box 4).

75. To try to understand better the contribution of different policy components, the following two sections of this paper seek to assess, first, the developments in wages, relative to a possible equilibrium level (Section V); and, second, the significance of changes in key policy variables in influencing the level of employment (Section VI).

\section{AN ANALYSIS OF THE WAGE GAP ${ }^{18}$}

76. The preceding sections have noted that the severity of the structural problems which plagued the Dutch economy at the beginning of the 1980s accounts in part for its impressive subsequent rebound, notably in the sphere of employment creation. In particular, it can be argued that, under the conditions of extreme labor market disequilibrium that prevailed in the early 1980 s, policies aimed at credibly reducing labor costs would be particularly effective in fostering employment growth. In addition, a situation of pronounced excess supply of labor, brought about in large part by wage increases in the previous decades that had far outpaced productivity growth, together with a fast growing population of working age and increasing willingness of women to seek employment, could have generated a self-correcting mechanism, by inducing labor unions to aim for more moderate wage increases.

77. This section attempts to provide a quantitative assessment of the extent of labor market disequilibrium in the Netherlands and its evolution that could allow a meaningful "benchmarking" of the Netherlands against a relevant set of comparator countries.

Specifically, what is of interest is a measure of the extent to which market wages have been in excess of the level at which firms would be willing to employ the full-employment level of the labor input, and of the evolution of this gap over time. It should be emphasized that such a measure, while indicating a desirable path for the average real wage in the economy, is a strictly demand-side indicator of labor market disequilibrium. Thus, while a closing of the gap between actual and market-clearing wages would certainly point to the potential to raise employment, the extent to which this increase in employment materializes may depend on a host of other factors: for instance, supply side constraints may be so pronounced as to limit seriously the numbers of persons willing to work at the lower wage, or negotiated wage scales may limit wage dispersion in a manner that impairs the clearing of the labor market.

78. The trend of the share of labor in total income is often considered as a reasonable measure to capture the evolving state of the labor market, in the sense described above. In this

\footnotetext{
${ }^{18}$ Prepared by Ioannis Halikias.
} 


\section{Box 4. Some Analytical Questions}

A number of analytical issues arise from experience in the Netherlands over the past decade and a half. These issues are relevant to assessing how far recent favorable trends in growth and employment may be extended in the future, and whether-or in what respects-policy experience in the Netherlands may carry lessons for other economies in Europe.

- An important feature of experience since the early 1980 s has been a sharp deceleration of real wage growth, associated with a pace of Job creation more rapid than that elsewhere in Europe:

- Should wage trends since the early 1980 s be viewed as an adjustment process in the face of a pronounced labor market disequilibrium at the start of the period (with much of the growth in employment reflecting the progressive reduction of a "wage gap")?

- How far does the explanation for wage moderation and employment growth lie in a demographic expansion of the labor force that was much faster than elsewhere in Europe?

- How important was the tightening of social benefits in expanding the effective supply of labor? For example, the minimum social benefit was frozen in nominal terms for extended periods-but an empirical assessment of the impact of this measure is not straightforward, especially in view of the linkage of the minimum benefit to the minimum wage.

- Finally, what role was played by the freezing of the national minimum wage and the application of youth minimum wages? These factors are sometimes held to account for much of the job creation since the early 1980s, by pricing the low-skilled and the young into jobs-but wage dispersion has changed little, and low-skill unemployment remains quite high.

- In assessing the continuing impact of policy initiatives over the past decade and a half, and the priorities for further reforms, three questions appear particularly relevant:

- While the labor share of income may still be on the high side relative to its equilibrium level, could the onset of adverse demographic trends early in the next century, making labor scarcer, mean the role of "wage moderation" in promoting job creation may be approaching its limits in the next few years?

- Given recent setbacks in cutting net inflows to disability, low overall participation in the labor force, and still high unemployment among the low-skilled-against a background of high income replacement rates under the unemployment and minimum benefit schemes-are more far-reaching measures needed to strengthen incentives on the supply-side of the labor market?

- To reduce unemployment among the low-skilled and those who have been out of the labor force for a long period, is greater wage dispersion needed; and if so is it viable to achieve this through a concerted and largely consensual wage-setting mechanism? 
respect, the trends in the Dutch economy have indeed been quite striking. While sharing with most other European economies a rise in the labor income share during the 1970s and early 1980s and a decline thereafter, the trends in the case of the Dutch economy have been much more pronounced (Chart 2). Economy-wide, the labor income share in the Netherlands rose from some 75 percent in 1970 to over 80 percent in $1980 ;{ }^{19}$ thereafter, it has declined to just over 72 percent by 1996 and is projected to keep falling over the medium term.

79. Suggestive as these trends may be, it has long been recognized that the labor income share is at best an imperfect proxy for the state of the labor market. From an international comparative perspective, one could expect the "equilibrium" labor share to depend strongly on the structure of the economy in question: for instance, a higher labor income share in a services-intensive economy relative to a manufacturing-intensive one need not signify a more pronounced labor market disequilibrium in the case of the former. Even on purely domestic grounds, there is no a priori reason to suppose that the equilibrium labor share should remain constant over time, especially in the face of significant changes in the relative supply of factors of production.

80. Accordingly, this section implements the methodology of the wage gap approach which, while making heavy use of the labor income share as a crucial variable, attempts to address the shortcomings described above. ${ }^{20}$ In essence, this approach entails estimating a production function, solving it for the labor income share that would be consistent with the high-employment level of the labor input given the level of the capital stock, and comparing this "warranted", or "equilibrium", labor income share with the actual labor income share. A substantial gap between the actual level of the labor share and its warranted level would suggest a significant deviation from labor market equilibrium.

81. In order to implement the wage gap methodology, one has first to specify a production function describing the relation between output to factors of production employed. As a first approximation, a constant returns to scale Cobb-Douglas production function, with capital and labor as inputs to the production process, was considered. The technical aspects of this specification, and estimation results, are discussed in Appendix I. The estimation results of Appendix I suggest an equilibrium labor income share of 64 percent. On the basis of this estimate, a wage gap estimate can be obtained as the difference between the actual labor income share from its equilibrium level. The wage gap over the period 1970-95 is plotted in Chart 25 (upper panel). To facilitate the setting of the Dutch experience in an international context, wage gaps for five other countries were calculated and plotted in Chart 25

\footnotetext{
${ }^{19}$ Excluding mining, the labor income share peaked at over 95 percent in 1980 . It can be argued that exclusion of mining may be justifiable for the purposes of an international comparison, given the importance of natural gas for the Netherlands during much of the period under consideration.

${ }^{20}$ For original formulations of the wage gap approach, with applications to industrial countries, see Artus (1984) and Lipschitz and Schadler (1984).
} 
CHART 25

NETHERLANDS

Wage Gap
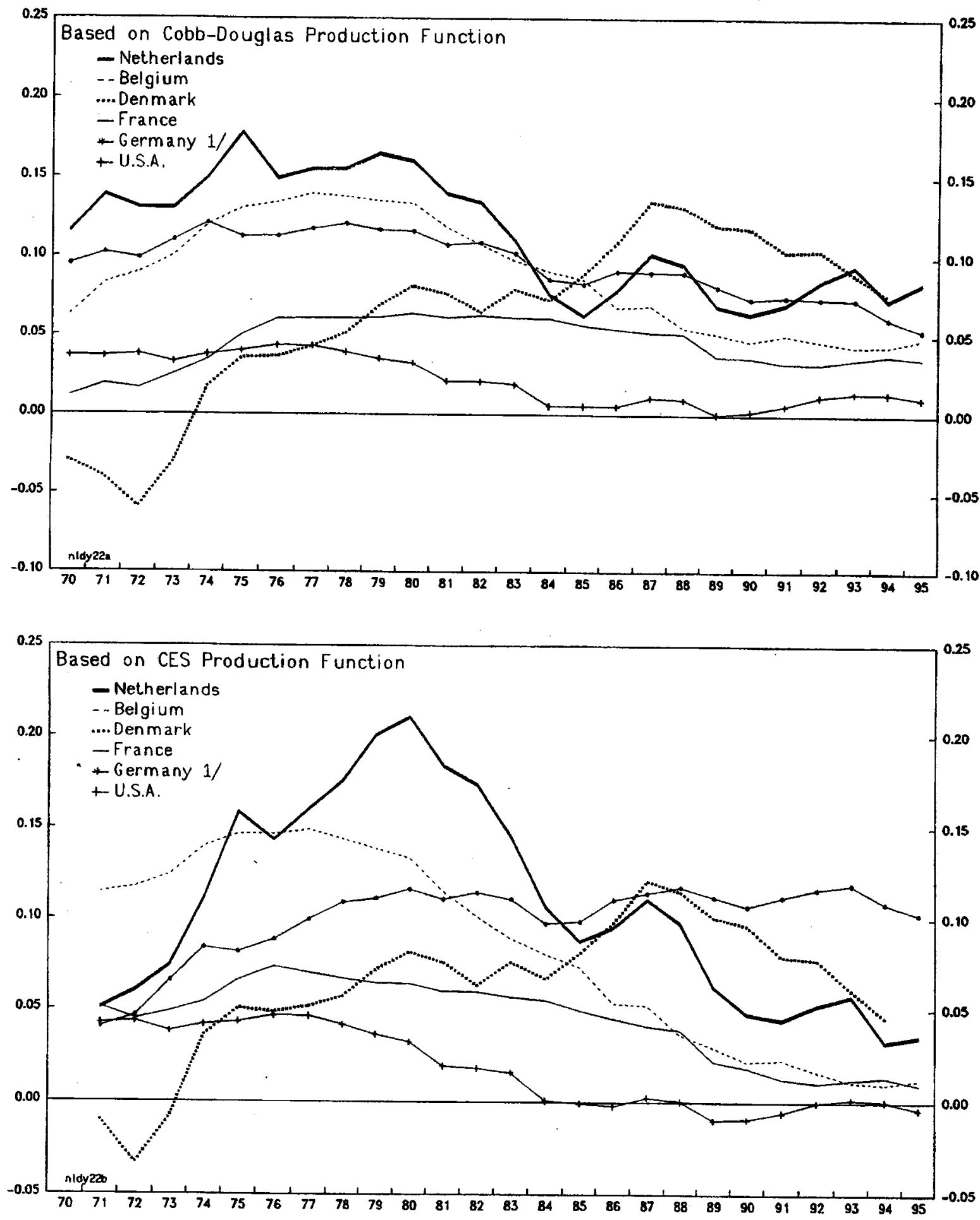

Source: Staff calculations.

1/ Capital and labor series have been smoothed to take account of the impact of reunification. 
(upper panel). In particular, four neighboring European countries (Belgium, Denmark, France, and Germany) were considered on the basis of their close integration with, and similar economic structure to, the Netherlands. The United States was also included as a relevant non-European comparator.

82. The trends of Chart 25 (upper panel) provide an indication of the severe labor market problems faced by the Netherlands until the beginning of the 1980s. While the Dutch economy shared with most other European countries a severe labor market deterioration throughout the 1970 s, the chart suggests that the problems faced by the Netherlands were relatively more severe, with the wage gap peaking at just under 20 percent, the highest level among the comparator countries. Since the early 1980s, however, there have been clear signs of improvement: the wage gap in the Netherlands has been declining rather steadily (with a brief pause during 1985-87), and currently stands some 10 percentage points lower relative to its 1970s peak. Nonetheless, the chart suggests that, despite this considerable improvement, some problems remain to be addressed. On the basis of the Cobb-Douglas specification, the wage gap in the Netherlands is still just under 10 percent, higher than in the comparator countries. This is rather surprising in view of estimates from various sources that the Dutch economy is operating close to capacity, and would indicate that some scope remains for a further downward correction of real wages in the Dutch economy.

83. The main attractiveness of the Cobb-Douglas specification employed so far stems from the fact that it is very simple to implement empirically and that interpretation of its parameter estimates is very straightforward. At the same time, however, it entails an important drawback. While controlling for country-specific technological features, the specification entails the rather undesirable feature of restricting the equilibrium labor share of income to remain constant over time, being unaffected by changes in factor proportions. This could render the resulting parameter estimates rather misleading, especially in situations where an economy's capital-labor ratio has changed substantially over time, as has been very much the case in the Netherlands during the period under consideration.

84. A popular alternative that sidesteps this problem is the constant-elasticity-ofsubstitution (CES) specification. For the purposes of this section, following Artus (1984), the constant returns to scale version of the CES specification is adopted, under which output is related to the two factors of production as follows:

$Y=\gamma \mathrm{e}^{\lambda t}\left[(1-\delta) L^{-\beta}+\delta K^{-\beta}\right]^{-1 / \beta}$

It should be noted that the CES production function described by equation (1) is a more general specification compared to the Cobb-Douglas one, in that it includes the latter as a special case: the CES approaches the Cobb-Douglas specification as the parameter $\beta$ approaches zero. In fact, this parameter is an important feature of the CES specification (and turns out to be particularly important for the purposes of this section): $\beta$ is inversely related to the elasticity of substitution between labor and capital $(\eta)$, via the expression $\eta=1 /(1+\beta)$. 
85. Econometric implementation of equation (1) is greatly facilitated by relying on a linear approximation of it. ${ }^{21}$ The new function is of the form:

$\ln Y=\ln \gamma+\lambda t+(1-\delta) \ln L+\delta \ln K-1 / 2 \beta(1-\delta) \delta[\ln (K / L)]^{2}$

Under the assumption that labor is employed up to the point where its marginal product (given the level of the capital stock) is equal to the real wage, straightforward algebraic manipulation of equation (2) yields an expression for the labor income share under the CES specification:

$S_{L}=(1-\delta)+\beta \delta(1-\delta) \ln (K / L)$

On the basis of equation (3), to get an expression for the equilibrium, or warranted, labor share, one has simply to substitute the "high employment" level of the labor input $\mathrm{L}^{f}$ in equation (3):

$S_{L}{ }^{e}=(1-\delta)+\beta \delta(1-\delta) \ln \left(K / L^{f}\right)$

86. Equation (4) underlines a crucial difference between the CES and the Cobb-Douglas specification. In contrast to the latter, the equilibrium labor income share under the CES specification will in general be sensitive to changes in factor proportions. However, the direction of change of $S_{L}{ }^{c}$ in response to a change in $\left(K / L^{f}\right)$ is, in general, ambiguous, and depends crucially on the sign of the parameter $\beta$. If, as often suggested by empirical work on a number of industrial countries, $\beta$ is positive (implying an elasticity of substitution of capital for labor that is less than one), then a situation in which the capital stock is growing faster than the high-employment labor input would entail a trend rise in the warranted labor income share.

87. The only remaining step before the empirical implementation of the CES production function is the estimation of the high-employment labor input $L^{f}$. To this end, the general methodology in Lipschitz and Schadler (1984) is followed, basing the estimate on the time path of the population of working age. ${ }^{22}$ In a departure from their methodology, however, it is recognized that the labor force participation rate itself includes a non-trivial cyclical component (the so-called "discouraged worker effect"). Thus, instead of the actual participation rate, its trend on the basis of a Hodrick-Prescott filter is used in estimating $L^{f}$. In addition, as the variable of interest is the level of the high-employment labor input rather than

\footnotetext{
${ }^{21}$ This approximation is obtained by writing equation (1) in logarithmic form, applying a Taylor's series expansion to $\ln Y$ about a value of $\beta$, which is then allowed asymptotically to approach zero, and dropping the terms involving powers of $\beta$ higher than 1. Kmenta (1967) shows that the resulting function provides a good approximation of the CES function over the relevant range of variations for $L, K$, and the various parameters.

${ }^{22}$ Artus (1984), on the other hand, bases the estimation of the high-employment labor input on an estimated Beveridge curve.
} 
its rate of change, use was made of the NAIRU for the Netherlands and the comparator countries from the World Economic Outlook database.

88. The model to be estimated consists of the (log-linear approximation of the) CES production function and a variant of the expression for the path of the labor income share:

$\ln Y=\ln \gamma+\lambda t+(1-\delta) \ln L+\delta \ln K-1 / 2 \beta(1-\delta) \delta[\ln (\mathrm{K} / \mathrm{L})]^{2}$

$S_{L}^{*}=(1-\delta)+\beta \delta(1-\delta) \ln \left(K / L^{*}\right)$

where

$S_{L}{ }^{*}=$ the trend-through-peaks value of $S_{L}$ adjusted downward so that the average of $S_{L}{ }^{*}$ is equal to the average of $S_{L}$, and

$L^{*}=$ the trend-through-peaks value of $L$ adjusted downward so that the average of $L^{*}$ is equal to the average of $S_{L}$.

The choice of the system of equations (5)-(6) deserves some comment. In the literature, a labor demand curve is sometimes utilized alongside the production function for the purposes of estimating the model's parameters. ${ }^{23}$ For the purposes of this section, however, the labor share equation (6) was utilized instead, as it would appear rather implausible to impose that labor is paid its marginal product, or that firms are on their labor demand schedule, even in the very short run. Indeed, a number of considerations, including firm-specific human capital, would suggest that changing the level of the labor input is not as costless as simple textbook models imply. Under these conditions, firms can be expected to base their hiring and firing decisions on longer term considerations, rather than on the basis of short run changes in relative factor prices. For the purposes of the present section, this would imply that a widening of the wage gap need not be associated by a contemporaneous large reduction in employment; rather, it may take a substantial cumulative widening of the wage gap for the full impact on employment to be felt. Correspondingly, these considerations would suggest that a substantial wage gap could coexist with the labor input near its high employment level for non-trivial periods of time.

89. With regard to the estimation methodology, inspection of equation (5) suggests that its separate estimation would in fact allow the identification of all the structural parameters of the model. However, in contrast to the case of the Cobb-Douglas specification, collinearity between the explanatory variables could impair the efficiency of estimation by ordinary least squares. Accordingly, following Artus (1984), the system of equations (5)-(6) is estimated

${ }^{23}$ The demand for labor associated with the CES production function is of the form:

$\ln L=(1+\beta)^{-1}(\ln \delta-\beta \ln \gamma)-(1+\beta)^{-1} \ln (w / p)-\beta(1+\beta)^{-1} \lambda t+\ln Y$, where $(w / p)$ is the real wage. 
jointly by non-linear least squares, while imposing the appropriate cross-equation restrictions. The estimation results regarding the model's parameters for the Netherlands are summarized in the tabulation below (asymptotic standard errors in parenthesis):

\section{CES Specification: Estimation Results}

$\begin{array}{lcccc}\ln \gamma & \lambda & \delta & \beta & \rho \\ 0.014 & 1.050 & 0.387 & 0.687 & 0.436 \\ (0.005) & (0.018) & (0.005) & (0.014) & (0.056)\end{array}$

Goodness-of-fit statistics

Production function SE $\quad 1.103$

Share function SE $\quad 0.203$

The parameter estimates were then plugged into equation (4) to obtain estimates of the time path of the warranted labor income share for the Netherlands and the comparator countries. On the basis of these estimates, wage gap series were constructed for each of the countries concerned, by subtracting the estimated warranted labor income share from the corresponding actual labor income share. These wage gap series are plotted in Chart 25 (bottom panel).

90. The trends of the wage gap for the Dutch economy based on the CES specification and those derived under the (more restrictive) Cobb-Douglas specification share a number of important qualitative features. In particular, the path of the wage gap under the CES specification confirms the substantial deterioration in the performance of the Dutch labor market during the 1970s and its subsequent recovery since the early 1980s. In addition, the estimate of the wage gap at the peak of the labor market deterioration, at just over 20 percentage points, once again turns out to be very high, both by Dutch historical standards and in comparison to other countries.

91. On the other hand, the estimated path of the wage gap under the CES specification also points to some interesting quantitative differences. In particular, its trends both during the deterioration and during the recovery phase turn out to be much steeper than suggested by the upper panel of the Chart 25. Thus, during the 1970s, the estimated wage gap rose from some 5 percentage points in 1970 to over 20 percentage points in 1980 . Its subsequent decline its estimated to have been just as steep, bringing it to under 5 percentage points by the mid1990 s. $^{24}$ In fact, it is interesting to note that throughout the 1990s the estimated wage gap falls substantially below that estimated for Germany.

92. Finally, a cautionary note would appear to be in order. While a widening of the wage gap can be interpreted as an exacerbation of the state of labor market disequilibrium in an economy, a closing of the wage gap should not be viewed as necessarily implying that full

\footnotetext{
${ }^{24}$ It should be noted that a point estimate of the wage gap under 4.5 percentage points is not statistically different from zero at standard significance levels.
} 
labor market equilibrium has been restored. Rather, what it would suggest is that only the type of disequilibrium associated with a high average wage level may have been successfully addressed, implying that the scope for a further dowmward correction of the real wage may have been largely exhausted. On the other hand, as noted at the outset of this discussion, the wage gap indicator does not carry implications for labor market problems that may be rooted in distortions on the supply side of the labor market, or indeed for situations where important distortions pertain to the dispersion of wages (rather than the average wage level). This point would appear to be currently pertinent for the Netherlands, and indeed for a country such as Belgium, where the success with closing the wage gap since the early 1980s (according to. Chart 25) was not accompanied by significant employment creation over the same period.

93. In summary, the analysis of this section suggests that the large wage gap that had emerged in the late 1970 s and early 1980 s clearly pointed to the desirability of a downward correction of the real wage, of the type that was achieved during the last decade and a half. At the same time, it would appear worthwhile to examine the main factors that may have contributed to the closing of the wage gap during this latter period, and the contribution of factors unrelated to the closing of the wage gap to the impressive employment creation in the Netherlands during the same period: such questions have obvious policy relevance for the Netherlands, but also for other countries facing similar labor market problems. Specifically, it would be interesting to inquire to what extent the closing of the wage gap in the Netherlands reflected the operation of a self-correcting mechanism in the face of pronounced adverse economic fundamentals, and to what extent policies aimed at reducing labor costs contributed usefully in this direction. Furthermore, one would like to assess the quantitative importance for employment growth of policies aimed at addressing distortions on the supply side of the labor market. These issues form the subject of the next section of this paper.

\section{SOURCES OF EMPLOYMENT GROWTH ${ }^{25}$}

94. The success with employment creation in the Netherlands since the early $1980 \mathrm{~s}$, described in the previous sections, has naturally attracted considerable interest among policy-makers and researchers alike. It is worthwhile trying to gain a better understanding of the main factors that may have contributed to this performance, which has been so much out of line with most of the rest of continental Europe. In particular, one would like to form an assessment of (a) the relative contribution of the initial conditions prevailing in the Dutch economy at the start of the 1980s and underlying demographic developments; (b) the role of the various aspects of the policy package adopted during the period under consideration, and the way they may have interacted with private sector behavior; and (c) the contribution of any shift in wage-setting behavior that may have been unrelated to the above two elements.

95. This section will attempt to provide a brief - and of necessity eclectic-summary and review of existing empirical work on these issues. In addition, it will describe and set out the

\footnotetext{
${ }^{25}$ Prepared by Ioannis Halikias.
} 
results of a series of simple empirical tests aimed at assessing the robustness of some of the conclusions reached so far and exploring a number of issues that may not yet have been fully addressed. The emphasis of this investigation will be on the impact of labor market policies and their interaction with some underlying trends in the Dutch economy-the hope being to shed some light on possible future priorities for policy in the Netherlands, as well as on the relevance of the Dutch experience for other economies facing similar labor market problems (topics that are addressed directly in the next section of this paper).

96. At the outset, a cautionary note is warranted. The interlinkages under investigation in assessing the sources of employment growth are particularly complex, involving relationships of a dynamic nature whose full effects may cumulate only gradually over time. At the same time, establishing the direction of causality is in some cases far from straightforward (especially given the rather small sample of data available). Under these conditions, the simple regression equations employed in this section will inevitably fail to do full justice to the issues under consideration. In particular, they offer a rather poor basis for forming reliable estimates of the quantitative impact of the various factors that may have contributed to employment creation in the Netherlands-and questions of this quantitative nature will be de-emphasized accordingly. ${ }^{26}$ Where the results may be more useful is in testing certain key hypotheses pertaining to the significance in explaining employment trends of certain key variables (either policy-related or not), after controlling for a different set of relevant variables.

\section{A. Wage Moderation and Employment Growth}

97. One of the first detailed studies of the determinants of employment growth in the Netherlands was undertaken by the CPB in $1991 .{ }^{27}$ By that time, it had become clear that the strong recovery of employment from its depressed levels of the early 1980 s was primarily structural, rather than cyclical, in nature; as such, empirical investigation of the main contributing factors appeared fully warranted. In its investigation, the CPB did not make use of its full-scale econometric model; indeed, unlike in that model, market wages were treated as fully exogenous. The quantitative estimates of this study are summarized in Box 5. In essence, the study concluded that the bulk of employment growth during that period was related to the moderation of average wage increases and to the de-linking of the minimum

\footnotetext{
${ }^{26}$ It should be emphasized, however, that large-scale econometric models, such as those developed by the Central Planning Bureau (CPB) in the Netherlands, do not necessarily fare much better in this regard: what they gain by way of simultaneous estimation of the relevant relationships, they may lose by the need to impose restrictions to achieve parameter identification (which may be somewhat arbitrary). Indeed, in the face of such onerous identification requirements, the CPB has chosen to impose (rather than estimate in the context of its full-scale model) a number of coefficients in certain key labor market relationships, presumably on the basis of empirical results obtained from smaller-scale models that rely on a methodology more or less similar to the one adopted in this section.

${ }^{27}$ See Centraal Planbureau (1991).
} 
Box 5. Employment Creation in the 1980s: The View of the Central Planning Bureau

The growth in employment in the market sector during 1983-1990 (500,000 persons) markedly contrasts with the decline in employment during 1975-1982 (250,000 persons). In other words, during 1983-1990, employment creation was 750,000 persons higher than in 1975-1982.

Research published by the Central Planning Bureau (Centraal Planbureau, 1991) tries to identify the causes of this dramatic change in performance. Using its macro-econometric model, the CPB performs a what-if analysis: by varying various domestic and international variables it tries to quantify the impact of the change in each variable.

The results of this study suggest that the difference in performance is not associated with international developments. Relevant world trade growth was only about 11/4 percent higher during the 1983-1990 period (accounting for 135,000 jobs out of 750,000); and about two thirds of this was offset by the increase in internationally determined real interest rates.

Thus, domestic rather than international factors are behind the change in performance. The CPB identifies two important domestic factors: wage moderation and the delinkage of wages in the collective sector, benefits and the minimum wage to contract wages. If there had been no wage. moderation, i.e., if the labor income share would not have declined, and if there had been no delinkage, employment would have been 400,000 persons lower in 1990.1

The delinkage of benefits, wages in the collective sector, and the minimum wage accounted for some 150,000 jobs out of the 400,000 . The delinkage reduced collective expenditure, thus lowering taxes and premiums, which resulted in 115,000 jobs; the remaining 35,000 jobs were the result of the relative decline of the minimum wage. The effect of the decline of the minimum wage was relatively modest, as in many cases the lowest wage scales rose in line with average contract wages, rather than in line with the minimum wage.

Wage moderation accounted for some 250,000 jobs. If the labor income share had not declined in the 1980 s, real wage costs would have been 17 percent higher in 1990 . While the impact on production in the market sector would have been modest (-1 percent, with lower exports and investment compensated in large part by higher consumption), enterprises would have reacted to higher wage costs by shedding more labor, and employment would have declined commensurately.

${ }^{1}$ The increase in part-time work accounted for another 150,000 jobs, while labor-time reduction contributed some 30,000 jobs. 
social benefit from contract wages, with the impact of the former factor almost twice as large as the impact of the latter. Overall, wage moderation would have accounted for perhaps one half of the increase in employment.

98. In what follows, an attempt is made to partially replicate these results-with the added benefit of a somewhat longer sample of years of employment creation. Specifically, in line with the Centraal Planbureau (1991) specification, the discussion below explores the impact on the rate of change in employment (DEMPL), ${ }^{23}$ of the rate of change in real average wages $(D R W)^{29}$ and of the minimum social benefit expressed as a percentage of the average wage (BENWAG)-i.e., essentially a replacement rate concept.

99. As this relationship is presumed to be a structural one, one needs to also control for the impact of the cycle on employment growth. ${ }^{30}$ In capturing the cyclical effect, two potential candidates were considered: the difference between the actual unemployment rate and the NAIRU and real GDP growth. The latter variable (DRGDP) was selected, mainly on two considerations: the intrinsic uncertainty about the level of the NAIRU, especially in view of structural reforms during the 1990s; and the likelihood that the real wage term would be more correlated with the unemployment term (and its lags) than with the real GDP term-which indeed proved to be the case.

100. Accordingly, an equation of the following form was estimated:

$\mathrm{DEMPL}=\alpha+\beta \mathrm{DRW}+\gamma \mathrm{BENWAG}+\delta \mathrm{DRGDP}$

In a simple reduced-form relation such as equation (1), one could still expect some collinearity problems between the explanatory variables, especially between DRW and DRGDP. Given the rather small size of the sample at our disposal, this could raise doubts about the reliability of individual coefficient estimates. To reduce the potential impact of this problem, we considered specifications that utilized the lagged value of either one of the two variables as an instrument for the corresponding contemporaneous variable.

\footnotetext{
${ }^{21}$ In the estimations of this section, several alternative definitions of employment were considered: total employment expressed in number of jobs, full-time equivalents and hours, and private sector employment expressed in full-time equivalents. As the estimation results were virtually identical across definitions, only the results involving total employment expressed in full-time equivalents are reported.

${ }^{29} \mathrm{As}$ in the previous section, the real wage variable (RW) includes employer social security contributions and payroll taxes.

${ }^{30}$ Indeed, not controlling for the cycle tended to generate estimates for the coefficient of the real wage term that were invariably insignificantly different from zero and often wrongly signed.
} 
101. The tabulation below presents the estimation results for a variety of specifications of equation (1). The equation was estimated by ordinary least squares, using annual data (t-statistics in parenthesis). ${ }^{31}$

Dependent variable: DEMPL

Estimation period: 1970-1995

Independent Variables

\begin{tabular}{|c|c|c|c|c|c|c|c|}
\hline Constant & DRW & BENWAG & DRGDP & $\mathrm{DRW}_{-1}$ & DRGDP $_{-1}$ & $\mathbf{R}^{2}$ & SE \\
\hline $\begin{array}{r}6.972 \\
(2.1)\end{array}$ & $\begin{array}{c}-0.208 \\
(1.9)\end{array}$ & $\begin{array}{r}-0.128 \\
(2.3)\end{array}$ & $\begin{array}{c}0.419 \\
(2.6)\end{array}$ & $\ldots$ & $\ldots$ & 0.43 & 1.201 \\
\hline $\begin{array}{r}6.608 \\
(2.0)\end{array}$ & $\ldots$ & $\begin{array}{c}-0.120 \\
(2.2)\end{array}$ & $\begin{array}{l}0.405 \\
(2.6)\end{array}$ & $\begin{array}{r}-0.217 \\
(2.1)\end{array}$ & $\ldots$ & 0.45 & 1.178 \\
\hline $\begin{array}{r}4.176 \\
(1.3)\end{array}$ & $\begin{array}{r}-0.369 \\
(3.1)\end{array}$ & $\begin{array}{r}-0.091 \\
(1.8)\end{array}$ & $\begin{array}{r}0.370 \\
(2.5)\end{array}$ & $\ldots$ & $\begin{array}{r}0.378 \\
(2.5)\end{array}$ & 0.55 & 1.083 \\
\hline $\begin{array}{r}4.111 \\
(1.3)\end{array}$ & $\ldots$ & $\begin{array}{c}-0.087 \\
(1.8)\end{array}$ & $\begin{array}{r}0.329 \\
(2.3)\end{array}$ & $\begin{array}{r}-0.342 \\
(3.2)\end{array}$ & $\begin{array}{r}0.347 \\
(2.4)\end{array}$ & 0.57 & 1.070 \\
\hline
\end{tabular}

The estimation results of the above table are broadly consistent with the conclusions of the CPB study. The estimated coefficients under all specifications are correctly signed, and the independent variables jointly account for about half of the variation in employment growth during the estimation period. In addition, albeit with the caveats discussed above, they tend to broadly confirm the conclusions in Centraal Planbureau (1991) regarding the relative quantitative importance of the factors that contributed to employment growth in the Netherlands since the early 1980s. In particular, the coefficient of the real wage variable is substantially larger than that of the replacement rate variable, and its significance level is generally higher-particularly when its lagged value is included as an explanatory variable.

\section{B. The Impact of Policies and Economic Fundamentals on Employment Growth}

102. Suggestive as the results based on such specifications may be, in many ways they raise as many questions as they answer. This is especially the case with the real wage variable: in principle, one would like to explore the main factors that drive the evolution of real wages themselves. From a strictly econometric viewpoint, causality issues may be particularly

\footnotetext{
${ }^{31}$ Standard Dickey-Fuller tests could not reject stationarity for the variables included in this specification, as well as in the specifications of the remainder of this section; accordingly, there was no need to resort to error-correction specifications of the relations under consideration.
} 
relevant: to the extent that the path of real wages partly depends on the state of the labor market, real wages and employment should better be viewed as jointly determined-which is by definition ruled out by the imposed exogeneity of the real wage variable in equation (1). From a broader perspective, for the specific case of the Netherlands, one would like to know whether the moderation of wage increases since the early 1980 s primarily reflected the initial state of labor market disequilibrium and the policy reforms adopted, or rather an "autonomous" shift in wage setting behavior on the part of labor unions-a question that is particularly relevant to potential replicability of the Dutch experience.

103. The specification of equation (1) also raises problems of interpretation of the BENWAG variable. Since this variable is essentially a replacement rate, one is tempted to view it as capturing the impact of policies that affect the incentive structure on the supply side of the labor market. However, as in the case of the Netherlands the minimum social benefit has been set at virtually the level of the minimum wage throughout the period under consideration, such an interpretation may not be fully warranted. While separating demand from supply-side effects of this nature often proves a difficult exercise in econometric practice, one would like to consider empirical tests that shed more light on the appropriate interpretation of the variable in question. In addition, Centraal Planbureau (1991) suggests another channel through which this variable may have affected employment growth: with a reduction of social benefits as a share of wages implying a reduction in social security premia, the resulting cut in labor costs could be viewed as boosting the demand side of the labor market. One would therefore like to control for such effects in order to obtain a better understanding of the impact of the replacement rate variable.

104. Shortly after the publication of the 1991 CPB study, staff at the Dutch Ministry of Economic Affairs embarked on an empirical investigation of the determinants of wages in the Netherlands-described in two interesting papers by Oudshoorn (1993a, 1993b) ${ }^{32}$ In particular, this work focuses on identifying the main factors that may have accounted for the decline in the labor income share since the early 1980s, making use of the wage equation in the CPB's FKSEC model. ${ }^{33}$ On the basis of this model, Oudshoorn (1993b) concludes that the decline in the labor income share between 1984 and 1989 can be adequately explained by underlying fundamentals and policy changes. In particular, 35 percent of this decline can be accounted for by a "Phillips curve" effect (captured by the level of the unemployment rate and its change), ${ }^{34} 30$ percent by the decrease in the "collective burden" of taxes and social security contributions, and 11 percent by a decline in the replacement ratio, with the remainder accounted for by the change in the terms of trade. Subsequent research by Ministry of

\footnotetext{
${ }^{32}$ For a critical appraisal of this approach, see Moons and Cornielje (1993) of the Dutch Ministry of Social Affairs.

${ }^{33}$ For a description of the model, see Central Planning Bureau (1992).

${ }^{34}$ While the Phillips curve effect does account for over a third of the decline in the labor income share, Oudshoorn underscores the remaining inflexibility of the Dutch labor market.
} 
Economic Affairs staff reportedly failed to identify a structural break in the relationship between the labor income share and these underlying variables: this would suggest that an "autonomous" shift in labor union attitudes in the early 1980 s probably played a minor role in explaining wage moderation since that time. Essentially, wage behavior responded to changes in economic and policy fundamentals.

105. In what follows, an empirical appraisal and some extensions of the work summarized in the previous paragraph are attempted. This is undertaken in three steps. First, an assessment is attempted of the empirical relevance of the factors considered by Oudshoorn (1993a, 1993b) for the variable of central interest of this section, i.e. employment growth in the Netherlands. Second, two types of empirical test are formulated and implemented (one of which will entail estimating a wage equation similar in structure to that in the FKSEC model) aimed at assessing any independent impact of wages on employment growth after controlling for the impact of certain key fundamental and policy-related variables. Third, these tests are utilized to assess the relevance for employment growth of policies aimed at improving the supply side of the labor market in the Netherlands.

106. The empirical results in Oudshoom (1993a, 1993b) suggest that the factors considered in that study may have played an important role in promoting employment growth in the Netherlands during the period under consideration. Nonetheless, a direct testing of this proposition would appear warranted. While there is a strong presumption that Dutch employment trends have been intimately connected with trends in the labor income share, the discussion in Section V suggests that this latter variable (and the closely associated wage gap) could conceivably decline, but other factors (for instance the prevalence of supply side constraints or marked shifts in the underlying paths of relative factor supplies) may prevent this decline from being translated into employment growth. ${ }^{35}$

107. This section therefore proceeds to test the impact on the rate of employment growth (DEMPL) of the replacement rate (BENWAG), the change in the payroll taxes and social security contributions (DBURDEN), and the unemployment rate (UNEMPL). ${ }^{36}$ In addition to the variables considered by Oudshoorn, the rate of change of the population of working age (DPOP15_64) was also included as an additional underlying factor that may have a bearing on employment creation. As in the specification of equation (1), the rate of growth of real GDP relative to trend is added, to control for cyclical influences. In order to minimize collinearity problems, we introduced the UNEMPL variable lagged once as an instrument for its contemporaneous level.

\footnotetext{
${ }^{35}$ In this regard, the experience of Belgium, where a substantial reduction of the wage gap during the same period was accompanied by hardly any employment creation, appears particularly illustrative.
}

${ }^{36}$ Of the variables utilized in Oudshoom (1993a, 1993b), the change in the unemployment rate was not included, because there is an obvious tautological, non-behavioral relation between a decrease in unemployment and an increase in employment. 
108. The equation to be estimated therefore is:

$$
\begin{aligned}
\text { DEMPL }=\alpha & +\beta \text { BENWAG }+\gamma \text { DBURDEN }+\delta \text { UNEMPL }_{-1}+\epsilon \text { DPOP15 } 64 \\
& +\zeta \text { DRGDP }
\end{aligned}
$$

Equation (2) was estimated by ordinary least squares over the period 1975-1995. The estimation results are as follows ( $t$-statistics in parenthesis):

$$
\begin{aligned}
& \text { DEMPL }=10.708 \text { - 0.289 BENWAG - 0.317 DBURDEN + 0.142 UNEMPL-1 } \\
& \text { (1.0) (2.4) } \\
& \text { + 2.794 DPOP15_64 + 0.512 DRGDP } \\
& \mathrm{R}^{2}=0.60 \quad \mathrm{SE}=0.996 \quad \mathrm{~F}(5,15)=4.5 \quad \mathrm{DW}=2.0
\end{aligned}
$$

The estimation results of equation (2) suggest that the factors considered are indeed important in explaining employment growth in the Netherlands during the period under consideration. It is noteworthy that, compared to the results of equation (1), the coefficient of the replacement rate increases substantially (in absolute value) under the specification of equation (2), while the contribution of the fiscal variable is also substantial, as suggested by a large body of empirical work in the Netherlands. In addition, the impact of the growth of population of working age on employment growth turns out to be positive and strong (albeit marginally significant), suggesting that the lag in the demographic cycle in the Netherlands relative to other European countries may have accounted to some extent for its superior performance in terms of employment creation.

\section{Impact of Fiscal Policy on Employment Growth: Some Qualifications}

109. Two aspects of the fiscal impact on employment growth, however, deserve further consideration. In the first place, there is some empirical evidence that the manner of financing of tax and premium cuts in Netherlands since the early 1980 s may have mattered crucially for their effectiveness in promoting employment creation. In a very interesting recent paper, Don (1996) examines the implications for employment of a reduction in taxes on labor that is financed by raising other, non-labor based, taxes. Specifically, he considers three alternatives for such offsetting tax increases: energy taxes, taxes on capital, and value-added taxes. He concludes that under all three alternatives such a balanced budget tax reform would have at best a minimal impact on employment. The implications of this finding for the issue under consideration are quite powerful. In particular, it would suggest that the strong impact on employment of the steady reduction of payroll taxes and social security contributions in the Netherlands since the early 1980s that is documented in Dutch empirical studies may have had a lot to do with the fact that these cuts were financed (in fact more than fully) by expenditure reductions rather than by increases in other forms of taxation. 
110. Second, it may be worthwhile to inquire whether the impact of changes in the fiscal burden on employment creation has remained constant throughout the period under consideration. In this connection, it could be argued that cuts in taxes on labor may have a more potent impact on employment growth in a situation of pronounced labor market disequilibrium than in a situation in which the labor market approaches its equilibrium position. Specifically, under conditions of pronounced excess supply of labor, a reduction in employers' contributions may not give rise to significant upward pressures on wages received by employees. On the other hand, with the labor market clearing, a similar reduction could be expected to entail increased competition for scarce labor, eventually driving up wages received by employees to a point where the beneficial impact (from the employers' point of view) of the tax cut on wage costs may be largely offset. Similar considerations may apply to a cut in premia levied on employees. In a situation of pronounced excess supply of labor, labor unions may be more willing to accept a cut in gross wages that would leave after-tax employee income little changed; by contrast, with labor fully employed, they may be more willing and able to resist such gross wage cuts.

111. In order to test this hypothesis, the coefficient $\gamma$ of the fiscal burden variable in equation (2) can be specified to consist of two distinct components: a constant and a component that depends on some measure of labor market disequilibrium. For this latter measure, the wage gap of Section V (WGAP) ${ }^{37}$ was chosen, as it captures precisely the extent of labor market disequilibrium associated with actual wages being above the level consistent with high employment. Thus, the coefficient $\gamma$ was specified as follows:

$\gamma=\gamma_{1}+\gamma_{2}$ WGAP, $\quad \gamma_{2}<0$

Substitution of equation (3) into equation (2) simply adds a cross term, DBURDEN*WGAP. The equation to be estimated thus becomes:

$$
\begin{aligned}
\mathrm{DEMPL}=\alpha & +\beta \text { BENWAG }+\gamma_{1} \text { DBURDEN }+\gamma_{2}{\text { DBURDEN*WGAP }+\delta \text { UNEMPL }_{-1}}+\epsilon \text { DPOP } 15 \_64+\zeta \text { DRGDP }
\end{aligned}
$$

The estimation results of equation (4), over the same sample period, were as follows ( $t$-statistics in parenthesis):

\footnotetext{
${ }^{37}$ Of the two wage gap estimates of Section V, the one derived on the basis of the CES production function was chosen.
} 


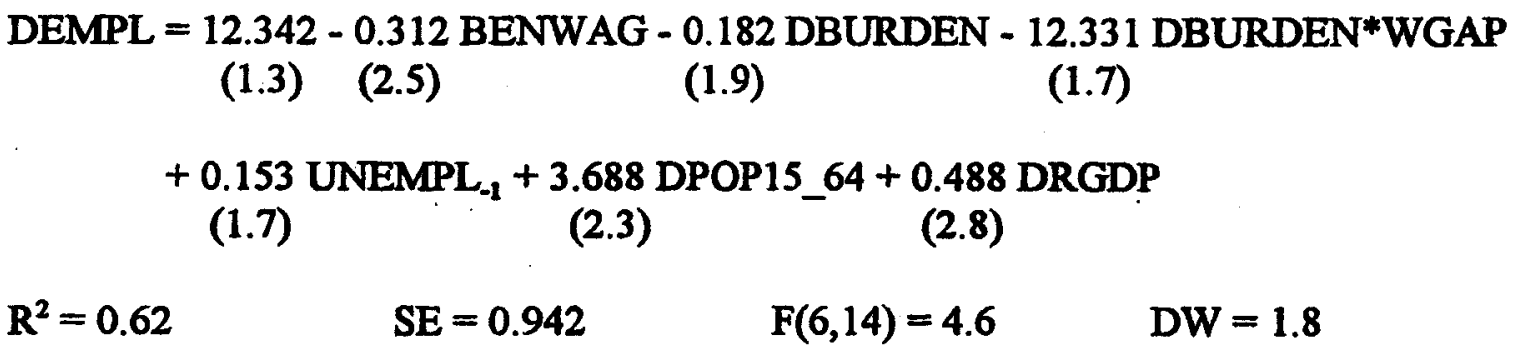

The estimation results broadly support the above hypothesis on the impact of the fiscal burden variable. In particular, under the specification of equation (4) the estimated coefficient of DBURDEN falls (in absolute value) relative to the estimation result of equation (2) to about half and its significance level declines. On the other hand, the coefficient of the cross term has the expected sign and is almost statistically significant.

112. Thus, the impact of tax and premium reductions on employment growth has tended to decline over the period 1980-1995 when the wage gap was steadily narrowing. Cuts in the tax on labor appear to have been more potent when the wage gap was large.

\section{Wage Moderation and Economic Fundamentals}

113. The historic Wassenaar Agreement of 1982, under which the Dutch labor unions adopted a policy of wage moderation, signaled a turning point in wage bargaining in the Netherlands. The discussion in Section V indicates that around the time of the Agreement, a very large wage gap had emerged in the Netherlands. Under these conditions, a substantial downward correction of the real wage was indeed entirely appropriate and urgently called for. An interesting question that emerges in this connection is to what extent the subsequent wage and employment developments (and in a sense the Wassenaar Agreement itself) largely reflected the impact of underlying, fundamental trends in the economy, and the policy reforms pursued over time by the authorities, or whether the Agreement had a major impact over and above this set of factors (in other words, whether there was a discernible and exogenous shift in labor union "preferences"). The question whether labor union leadership essentially rearticulated wage policy in a manner which internalized changes in the economy and in the policy framework is particularly relevant to the broader replicability of the past experience in the Netherlands.

114. To address this issue, this section proceeds to examine to what extent the trends in employment growth in the Netherlands can be adequately accounted for by the fundamental and policy-related factors that have been the subject of the empirical investigation so far, or whether one can identify a discernible break in the relation between these factors and wage and employment trends at (or around) the time of the Wassenaar Agreement. A standard econometric response to such a question would be to break up the available sample of time series observations into two sub-periods around the time of the Agreement, and perform Chow F-tests for parameter stability over the two sub-periods; however, the size of the 
available sample relative to the number of explanatory variables under consideration rules out this approach in our case.

115. Instead, two types of statistical tests may be considered to shed some light on this question. The first, discussed below, is relatively straightforward: it entails introducing real wage growth as an explanatory variable in equation (2), and test whether its introduction adds anything to the explanation of employment growth beyond what is already contained in the independent variables of equation (2). Relevant criteria in this regard include the overall equation fit and the size and significance level of the coefficient of the added real wage variable itself. As in the empirical implementation of equation (1), the contemporaneous or the lagged value of real wage growth (DRW) were alternatively utilized as the additional explanatory variable.

116. The equations to be estimated therefore are:

$$
\begin{aligned}
\mathrm{DEMPL}= & \alpha+\beta \text { BENWAG }+\gamma \text { DBURDEN }+\delta \text { UNEMPL }+\epsilon \text { DPOP15_64 } \\
& +\zeta \text { DRGDP }+\eta \text { DRW } \\
\text { DEMPL }= & \alpha+\beta \text { BENWAG }+\gamma \text { DBURDEN }+\delta \text { UNEMPL }+\epsilon \text { DPOP15_64 } \\
& +\zeta \text { DRGDP }+\eta \text { DRW }_{-1}
\end{aligned}
$$

Equations (5) and (5') were estimated by ordinary least squares over the period 1975-1995. The estimation results were as follows (t-statistics in parenthesis):

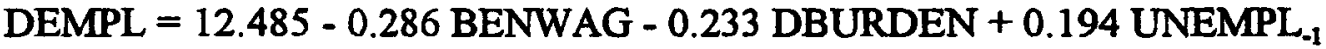

$$
\begin{aligned}
& \text { + 2.965 DPOP15_64 + 0.516 DRGDP - 0.154 DRW } \\
& \mathbf{R}^{2}=0.62 \\
& \mathrm{SE}=1.007 \\
& F(6,14)=3.7 \\
& \mathrm{DW}=1.8 \\
& \text { + 2.655 DPOP15_64 + 0.582 DRGDP + 0.091 } \mathrm{DRW}_{-1} \\
& \mathrm{R}^{2}=0.58 \quad \mathrm{SE}=1.051 \quad \mathrm{~F}(6,14)=5.0 \quad \mathrm{DW}=1.9
\end{aligned}
$$$$
\text { DEMPL }=13.618-0.252 \text { BENWAG }-0.245 \text { DBURDEN + 0.205 } \text { UNEMPL }_{-1}
$$

The estimation results of equations (5) and (5'), involving real wage growth as independent variable, appear quite clear-cut. The coefficients of the $D R W$ and $D_{R W_{-1}}$ variables are insignificant at conventional significance levels-indeed, under the lagged specification, the corresponding coefficient is incorrectly signed. In addition, the coefficients of the remaining 
explanatory variables, and the overall equation fit, as captured by the $R^{2}$, standard error and $F$ statistic, are hardly affected by the introduction of the real wage variable. It would appear, based on this specification, that the independent variables of equation (2) adequately account for the trends of employment growth, with real wage growth in its isolation providing virtually no additional explanatory power.

\section{E. The Relevance of Supply-Side Policies}

117. A problem with the specification of equations (5) and (5), also noted above, is that the real wage variable, especially when its contemporaneous value is utilized, may be highly correlated with the other independent variables. Given the small sample size, this would in general tend to bias individual coefficients, rendering interpretation of the estimated equation rather tricky. These problems provide the motivation to implement a second type of test, which almost by definition side-steps such collinearity problems.

118. This second test proceeds in two distinct steps. First a wage equation is estimated that links real wage growth to a set of underlying and policy-related variables. Then, the predicted real wage growth on the basis of the wage equation and the part of real wage growth that is unexplained by that equation are entered separately as explanatory variables of employment growth. The test amounts to examining whether the component of real wage variable that is unexplained by the fundamental and policy-related variables has a coefficient that is significantly different from zero. The collinearity problems are side-stepped because the two components of real wage growth are, by construction, completely uncorrelated (or orthogonal) to each other.

119. First a wage equation is estimated. The equation to be utilized is very similar in structure to the wage equation of the CPB's FKSEC model. ${ }^{38}$ Thus the explanatory variables of real wage growth include the replacement rate, the change of the fiscal burden, the unemployment rate and the change in the unemployment rate (DUNEMPL). The CPB's equation is not simply adopted for, essentially, three reasons. First, a number of coefficients of the CPB's wage equation are imposed rather than estimated, presumably in order to facilitate identification of the large-scale model. Second, it appears useful to introduce the growth of the population of working age as an additional explanatory variable, given that it performed well in the employment equations estimated above and that it appears relevant on theoretical grounds. ${ }^{39}$ Third, relying on the CPB's wage equation to generate the predicted and residual

\footnotetext{
${ }^{38}$ The CPB justifies its wage equation on the basis of a bargaining model in an "insideroutsider" setting. However, since the actual variables selected would appear to be consistent with a variety of models, including more conventional ones, we are inclined to remain rather agnostic on this point.
}

${ }^{39}$ The CPB actually acknowledges that inclusion of this variable would be consistent with (continued...) 
components of real wage growth would not guarantee that the two components would in general be orthogonal to each other.

The equation to be estimated therefore is of the form:

$\mathrm{DRW}=\alpha+\beta$ BENWAG $+\gamma$ DBURDEN $+\delta$ UNEMPL $+\epsilon$ DUNEMPL $+\zeta$ DPOP15_64

Equation (6) was estimated by ordinary least squares for the period 1975-1995. The estimation results are as follows ( $t$-statistics in parenthesis):

DRW $=-8.483+0.448$ BENWAG + 0.272 DBURDEN - 0.267 UNEMPL

- 0.296 DUNEMPL - 4.596 DPOP15_64
$\mathbf{R}^{2}=0.58$
$\mathrm{SE}=1.652$
$F(5,15)=4.7$
$\mathrm{DW}=2.1$

The empirical performance of the equation appears to be reasonably satisfactory. All explanatory variables have correctly signed coefficients, and the coefficients of the replacement rate, the unemployment rate and the growth of population of working age variables are highly significant. At the same time, the explanatory variables jointly determine about half the variation in real wage growth. This leaves a non-trivial residual to be utilized in the second part of the empirical test.

120. On the basis of the estimation results of equation (6), the predicted component of real wage growth (DRW') and its unpredicted component (DRW ${ }^{\wedge}$ ) can be constructed. These variables are introduced separately as explanatory variables in the employment growth equation. We also include as additional explanatory variables de-trended real GDP growth, to correct for cyclical factors, and the replacement rate.

121. The inclusion of the replacement rate independently of its impact on real wage growth, which in fact constitutes the second motivation for implementing this second type of test (i.e., apart from the need to side-step multicollinearity problems), warrants some discussion. As noted at the outset, it would be important to distinguish between the demand-side and the supply-side impact of the replacement rate on employment growth. Such a distinction is rendered particularly difficult in the case of the Netherlands by the near-equality of the minimum social benefit and the national minimum wage. The empirical test now being implemented should allow identification the supply-side effect, at least at a minimum. The

\footnotetext{
${ }^{39}$ (...continued) certain bargaining models from which its wage equation can be derived. See Central Planning Bureau (1992), p. 32.
} 
intuition is relatively straightforward. The impact of a replacement rate cut on the demand side of the labor market (either directly through the minimum wage cut or indirectly through the lowering of payroll taxes and social security premia) should be fully captured by its impact on the real wage. On the other hand, the supply side impact of a reduction in the replacement rate should be partly felt via its effect on the wage rate (with an effective increase in labor supply possibly putting downward pressure on average market wages) and partly directly on employment, as a cut in benefits creates an incentive for people to work at the going market wage rate. Hence, while the $\mathrm{DRW}$ component embodies a mixture of demand and supplyside effects of the replacement rate, its direct contribution when introduced alongside the DRW" variable has to embody only (part of) its supply-side effects.

122. The equation to be estimated is therefore of the form:

$\mathrm{DEMPL}=\alpha+\beta \mathrm{DRW}^{\mathrm{pr}}+\gamma \mathrm{DRW}^{\perp}+\delta \mathrm{BENWAG}+\epsilon \mathrm{DRGDP}$

Equation (7) was estimated by ordinary least squares over the period 1975-1995. The estimation results are as follows (t-statistics in parenthesis).

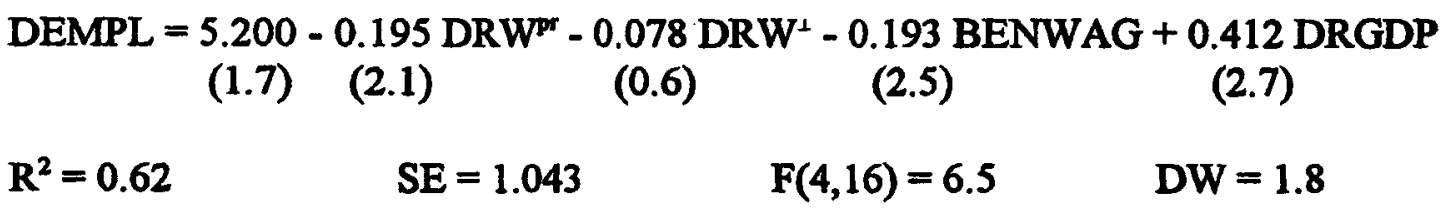

123. The estimation results of equation (7) carry rather clear-cut implications. On the question of any autonomous contribution of wage moderation to employment growth in the Netherlands, over and above what would be implied by underlying fundamental trends and policy changes, this contribution appears to be negligible. The coefficient of the residual component of real wage growth turns out to be near-zero. On the issue of the supply-side contribution of changes in the replacement rate, on the other hand, the empirical results suggests that it is substantial, with the coefficient of the BENWAG variable quite large and strongly significant. Taking into account the very large decline in the replacement ratio since the early 1980s, it can be computed that it helped generate employment growth of at least 5 percent on the supply side alone during the 1980-1995 period; it should of course be recalled that this estimate represents only a lower bound, in abstracting from the supply-side impact of a reduction in the replacement rate that may have worked through a reduction of average real wage growth.

\section{F. Employment Growth and the Broader Policy Setting}

124. The discussion above attempts to shed some light on the process of employment creation in the Netherlands. The essence of the case presented is that the initial conditions in the labor market, and underlying demographic trends, both appear to have been important in the determination of wages and employment, but that the policy approaches adopted by the authorities from 1982 onwards have also been very important. Among these policies, the 
reduction in the tax on labor made a significant contribution, but with some question mark over its future potential in this regard; by contrast, policies to strengthen supply side incentives in the labor market, which also played an important role, may hold the best promise to promote sustainable employment growth in the future. At the statistical level, a number of caveats need to be borne in mind, given the nature of the data in the sample: as indicated at the outset, undue reliance should not be placed on the precise quantitative implications of the assessment above- but the general direction of the findings, and their correspondence with the conclusions of earlier studies in the Netherlands, appears. strongly suggestive of the factors that have underlain labor market performance.

125. Standing back from the specific issue of employment growth, and the challenge of estimating its sources, four broader considerations appear relevant, and need to be weighed before reaching final conclusions on the implications of this experience.

- The improvement in economic performance in the Netherlands described earlier in this paper is a much wider phenomenon than is captured by the trend in employment growth alone. The essence of the experience was a virtuous circle, in which labor market developments, fiscal performance, and household confidence combined to produce outcomes that may appear significantly greater than the sum of the parts.

- Any assessment of the medium- and long-term outlook in the Netherlands similarly needs to embrace the interaction of labor market developments with trends in overall economic performance and the trajectory of the public finances. Moreover, this must be assessed in a demographic setting quite different from that experienced in the past.

- Given different starting conditions and demographic trends, one of the most important issues for the future lies in the way in which policies might need to be re-balanced to prolong this successful performance.

- Finally, in a number of respects it is this latter, forward-looking scenario that may be more relevant to other countries, to the extent they face employment, demographic, and fiscal problems which appear more closely comparable with those in the Netherlands today than those 15 years ago. Any assessment of these forward-looking issues must be to some extent conjectural. However, it appears worthwhile to attempt some quantitative exploration, if only to point to relevant issues for future research. This is the objective of the remainder of the present paper. 


\section{Vif. Assessing the CuRrent OUTLOOK ${ }^{40}$}

126. This section attempts to bring together a number of empirical findings discussed in Sections V and VI of this paper and to assess their possible implications for policy priorities in the coming years-in the Netherlands and possibly in other European countries also. The discussion below considers the possible contribution of different policy approaches to stimulating employment in the future; and, second, attempts to place this assessment in the broader setting of the long-run fiscal outlook in the Netherlands.

\section{A. The Employment Outlook}

127. On the basis of the empirical results obtained in this paper, as well as the results of past work in the Netherlands, the Dutch experience since the early 1980 s appears to point to three types of general conclusion with strong policy relevance: (a) initial conditions in the labor market and underlying trends appear to have mattered a lot for wage and employment outcomes, but their impact was considerably reinforced by comprehensive policy reforms; (b) efforts to reduce taxes on labor had considerable effects on wages and employment, albeit with important qualifiers that may raise questions about the extent of their effectiveness in the future; and (c) policies to improve the incentive structure on the supply side of the labor market also played an important role, and probably hold considerable promise for promoting sustainable employment growth in the future.

128. The empirical results of Section V suggest that by the early 1980 s a substantial wage gap had emerged, in the sense that wage costs had risen to a much higher level than that would be consistent with high employment-indeed, this wage gap appears to have been much larger than in most other European countries. In addition, with the demographic cycle associated with the "baby boom" lagging behind in the Netherlands relative to other European countries, natural labor supply growth was quite strong: under these conditions, it became clear that failure of wage costs to adjust would seriously exacerbate the already pronounced disequilibrium of the Dutch labor market. The empirical results of Section VI suggest that such underlying fundamental factors had a strong impact on both real wages and employment, pointing to the presence of a strong self-correcting mechanism in the face of pronounced labor market disequilibria.

129. On the other hand, the empirical results suggest that the wage gap has been closing rapidly in recent years, with wage costs converging to a level consistent with high employment. In that sense, the Dutch economy has been approaching the situation prevailing in most other European countries (Germany being something of an exception). In this context, given labor supply, the major contribution of wage moderation to employment growth may have run much of its course, and in that sense one would need to look for an appropriate balance of labor market policies to sustain employment growth.

\footnotetext{
${ }^{40}$ Prepared by Ioannis Halikias.
} 
130. Regarding the sustained efforts to reduce the burden of payroll taxees and social security contributions, the empirical results of this paper confirm to a large extent the findings of past empirical work in the Netherlands. These policies appear to have contributed to the moderation of wage costs, thus complementing the impact of self-correcting wage adjustment in the face of pronounced excess supply of labor. Further reductions of the fiscal burden from its currently still very high level would be desirable. On the other hand, two considerations regarding the pattern by which such policies appear to have made their impact on the Dutch labor market need to be borne in mind when assessing their effectiveness in supporting employment growth in the future:

- The empirical research by the CPB (Don, 1996), referred to above, concluded that the manner in which tax cuts on labor are financed matters a lot for their effectiveness in terms of promoting employment creation, and cast strong doubt on the presumption that tax reform that shifts the tax burden away from labor toward energy, capital, or valued-added can have a strong impact on labor market performance. To the extent that the success of such policies in promoting employment in the past had a lot to do with the fact that they were "financed" through steep expenditure reduction, it can be conjectured that, for these policies to remain successful in this regard, progress with expenditure control needs to be maintained. That is, of course, by no means easy to achieve given the increased pressure on spending related to the ageing of the population and the fact that capital expenditures have already been cut quite substantially.

- The findings of Section VI of this paper suggest that the effectiveness of cutting payroll tcoces and social security contributions in boosting employment growth also depends on the degree of labor market disequilibrium. Specifically, such cuts tend to be more effective in a setting of a high wage gap than in a situation in which the labor market approaches equilibrium. As the empirical results of this paper show that the wage gap in the Netherlands has already narrowed quite substantially, this consideration raises questions regarding the extent of the effectiveness in terms of employment growth of policies to reduce taxes on labor.

131. Taken together, these two considerations would suggest that some rebalancing of the "mix" of Dutch labor market policies may be in order. The empirical results of Section VI strongly suggest that efforts to improve the incentive structure on the supply side of the labor market, as captured by the replacement rate, were particularly important in accounting for employment growth since the early $1980 \mathrm{~s}^{41}$ indeed, the results may suggest that the impact of such policies in the case of the Netherlands may have been stronger than is usually thought. With the Dutch economy, along with most other European economies, approaching equilibrium on the demand side of the labor market, and with supply-side problems increasingly becoming the binding constraint on continued employment growth, there is a

\footnotetext{
${ }^{41}$ In focussing on the replacement rate, the paper abstracts from other, "non-price", supply side measures, including the tightening of eligibility criteria for certain social security schemes, notably disability insurance.
} 
strong case for putting greater emphasis on policies of this type, relative to demand-side policies.

132. The urgency of strengthening the supply side of the labor market is only partly captured by the overall labor force participation rate, which is among the lowest in the industrial world when expressed in full-time equivalents. The extent of the problem can be better gauged by looking at the participation rate broken down by age group:

Table 2. Netherlands: Participation Rate by Age Group

(In percent)

\begin{tabular}{lccccc}
\hline & $15-24$ & $25-34$ & $35-44$ & $45-54$ & $55-64$ \\
Participation & 44.4 & 80.4 & 76.3 & 68.4 & 26.9 \\
\hline
\end{tabular}

Sources: Ministry of Social Affairs, Sociale Nota 1997; and staff calculations.

133. The above tabulation suggests that the low overall participation rate in the Netherlands in large part reflects the very low rate of the older age group; it is in this age group where the incidence of early retirement and disability is the highest (also, this group is exempted from job search requirements in order to receive unemployment benefits). The seriousness of the present situation is latent, in that the Dutch labor force is still relatively young: with the onset of ageing, the share of the older age group in the overall population of working age is set to start rising already over the medium term. Under these conditions, if the cohorts entering the older age group display the same behavioral characteristics with regard to the social security schemes referred to above, the overall participation rate is set to fall further.

134. An additional question relates to the types of policies that could be considered. A case can be made that one needs to continue with the tightening of eligibility criteria, as has been the preferred policy during the 1990s, especially with regard to social security schemes where abuse remains very high. Ultimately, however, renewed progress could need to be made in addressing once again the replacement rate itself, especially at the low end of the labor market where it remains very high.

135. A closely related issue is the possibility that continued success with employment growth in the Netherlands, and greater progress in reducing unemployment among the lowskilled, could also depend on increasing wage dispersion at the lower end of the labor market. A point of concern has been that contract wage floors are increasingly higher than legal minimum wages. In this connection, the recent initiatives to extend downward wage scales in sector wage agreements appear important: this would remedy insider-outsider problems. However, if wage dispersion does not increase in practice, a clear possibility would be that the replacement rate of benefits is setting, at the low end, too high a floor under wages. Once 
more information becomes available on the success of the recent initiatives, the issue of the replacement rates at the lower end of the labor market may need to be reviewed.

136. To the extent the above conclusions hold true, they underscore that experience over the past 15 years should be viewed as very relevant in assessing future policies, but not directly replicable in the period ahead or, a fortiori, in other countries (Box 6). The effective application of rather orthodox policy reforms, on the one hand, carries clear messages; on the other hand, the starting conditions were markedly different from today's circumstances in the Netherlands or in a number of other European economies-with wages now on average close to equilibrium, and adverse long-run demographic trends lying ahead. This implies that some rebalancing of reforms would be called for. In particular, supply-side measures in the labor market could well be of crucial importance, and social security reforms to avoid an unmanageable growth in age-related public expenditure take on far more urgency. The remainder of this section seeks to explore the possible interaction of these policy approaches over the longer term.

\section{B. The Long-Run Fiscal Outlook}

137. Moving from medium-term priorities to longer-term policy issues is obviously a difficult exercise; among other considerations, the behavioral relationships from which the results in Sections V and VI above were derived may undergo substantial shifts over time. Nonetheless, it is hoped that the empirical analysis can provide at least some broad outlines of the likely future evolution of certain key variables, and suggest some useful indications regarding the impact of policies in the future.

138. From a long-term perspective, the dominant factor likely to affect policy outcomes is probably the projected ageing of the population over the first half of the next century. While the Netherlands shares these adverse demographic trends with virtually every other industrial country, certain distinctive features are noteworthy. The demographic cycle in the Netherlands is lagging behind that in other countries, in featuring still a relatively young population. On the other hand, the magnitude of the demographic shock, expressed in terms of the old age 


\section{Box 6. Is the Experience with Policy Reform in the Netherlands Replicable?}

The turnaround in economic performance has been hailed by some as "the Dutch miracle," and an example for other ecomomies. But are all of these "lessons" necessarily replicable? How far did the success depend an specificities of the economic, political, and cultural setting 15 years ago?

- It can certainly be argued that the Netherlands, as a very open economy, faced with a crisis, had little choice but to opt for flexibility, to remain competitive in a climate of increasing globalization: there was a sense of urgency which may not be present to the same degree in other countries.

- The approach to reform was gradual, and implementation broadly consultativo--but this can be overstated. While there was a consensus from the beginning on wage moderation, other reforms were initially resisted: acceptance developed only over time. Moreover, the change in wage-bargaining approach by the labor unions was to a high degree an endogenous response to the government's "changing the rules of the game" - cutting benefits and minimum wages, and offering income gains through tax cuts under a new fiscal strategy. The style was sui generis, the content orthodox.

- The improvement in overall performance was accompanied by a slowdown in productivity growth, which may appear a negative aspect of the experience. This slowdown, however, reflect-at least in part-the impact of a reversion toward equilibrium relative levels in the factors of production, as well as some compositional effects resulting from low-skilled employment creation (for example, youth employment) - in themselves positive developments.

- Unique initial conditions on the supply side of the labor market clearly amplified the impact of reforms (although they could have exacerbated unemployment in the absence of strong job creation). These conditions included a low labor force participation rate, with relatively few women in the workforce; rapid demographic growth, which underpinned wage moderation; and the existence of a large wage gap, reduction of which triggered rapid employment growth. This was a setting propitious for measures on the demand side to be effective; in more typical circumstances, even stronger supply side measures would have been needed to foster such strong employment growth.

- Recent performance is in part a correction or catch-up with neighboring countries, from an alarming starting position. Indeed, the overall tax burden and debt ratio are still excessive, and labor force participation-adjusted for demographics and in full-time equivalents-remains low, the numbers receiving disability and unemployment benefits are still close to record highs. In this connection, observers focusing on a single summary statistio-published unemployment, as low, or hidden unemployment, as high-may be missing the essence of the "lessons" from the experience in the Netherlands. The interest of the reforms lies rather in the remarkable employment creation and turmaround in participation achieved since the early 1980 's. The "stock" or "level" problems that remain serve mainly to emphasize that the reform process is still far from complete.

In sum, various "special" features clearly enhanced the impact of reforms; but they do not detract from the general policy lessons. In essence, the "Dutch miracle" is neither a miracle nor uniquely Dutch, but rather illustrates the mutually-reinforcing inpact and central importance of relatively orthodox reforms, both macroeconomic and structural, pursued consistently over a long period. 
dependency ratio at the peak, is projected to be significantly larger in relation to relevant comparator countries (see tabulation below):

Table 3. Netherlands: Old-Age Dependency Ratio ${ }^{42}$

(In percent)

\begin{tabular}{llllll}
\hline & 1990 & 2000 & 2010 & 2020 & 2030 \\
\hline Netherlands & 18.6 & 20.6 & 23.7 & 32.8 & 44.1 \\
Belgium & 21.9 & 24.7 & 25.0 & 30.2 & 38.9 \\
France & 20.8 & 23.6 & 23.6 & 30.2 & 37.5 \\
Germany & 21.5 & 24.1 & 30.6 & 33.4 & 41.5 \\
United Kingdom & 23.7 & 23.6 & 24.4 & 29.2 & 36.8 \\
EU average & 21.2 & 23.6 & 26.0 & 30.3 & 37.5 \\
\hline
\end{tabular}

Source: United Nations, Long Range World Population Projections, 1994.

139. The main impact of these adverse demographic trends is likely to be felt in the fiscal area. This impact, in turn, operates via two distinct channels. First, ageing of the population is estimated to put strong upward pressure on certain age-sensitive categories of social security expenditure, notably in the areas of pensions and health care (Boxes 7 and 8). Second, in the absence of offsetting policies, ageing would translate into an adverse labor supply shock, thus lowering the economy's productive potential and raising the share in GDP of the age-sensitive expenditure. The combined impact of these two factors is projected to entail a net burden on the general government primary budget of some 7 percentage points of GDP at the peak of the demographic shock. ${ }^{43}$ The essential message that emerges from such fiscal projections has been borne out by approaches based on generational accounting (Box 9).

140. A possible policy response to these adverse demographic trends is illustrated in Appendix II of this paper. In essence, it consists of bringing the general government budget into a small surplus over the medium term in order to ensure sufficient interest savings to offset to a significant extent the demographics-related increased spending. In addition, further structural reforms in pensions and health care should allow the fiscal costs of the demographic shock to be reduced somewhat below current estimates of some 7 percent of GDP.

${ }^{42}$ Ratio of the number of people 65 years and older to the number of people between 15 and 64 years old.

${ }^{43}$ For a discussion of these estimates see SM/94/100 and SM/96/118. 


\section{Box 7. The Pension System-An Overview}

\section{Pensions}

Pensions in the Netherlands typically consist of two elements: a public, universal pension; and supplementary private pensions.

The public pension for a single person is equal to 70 percent of the legal minimum wage, and for each person of a married or unmarried couple, the pension is equal to 50 percent of the minimum wage. The pension is universal in that any resident, whether in the labor force or not, is eligible. It is financed through a payroll tax, levied on anyone below 65 .

Supplementary pension funds provide benefits under defined-benefit plans, with the promised total pension (i.e., including the public pension) at age 65 generally equal to 70 percent of pay in the last year of several years for an employee with a complete work history (at least 40 years); the pension is prorated for years worked. Supplementary pensions are financed through premiums of employers and employees to fully funded private pension funds. Given their enshrinement in collective agreements, they are essentially mandatory in character.

Due to the aging of the population, pension premiums will rise significantly in the future. Available projections suggest a rise in premiums for public and supplementary pensions from around 17 percent of gross wages currently to some 35-40 percent in about four decades (SM/96/118).

To avoid excessive increases in public pension premiums, the government has taken two measures. First, the premium percentage has been capped at the 1996 level, with any excess of expenditure over revenue being financed out of the budget; second a fund has been established that will build up reserves for future pension expenditures.

Apart from this, a combination of policy options could be considered to restrain the growth of spending on public pensions, to side-step any risk of calls for fiscal support as a result of rising supplementary pension premiums, and to avoid a substantial worsening of incentives in the labor market:

- increasing the retirement age for public pensions;

- $\quad$ indexing public pensions at less than the rate of increases of wages;

- $\quad$ restructuring the design of the supplementary pension plans to underscore their individual insurance content (e.g., by encouraging flexibility in the overall level of pensions, now often set at 70 percent of the last wage, to slow projected increases in premiums); and

- $\quad$ more generally, preparing for the rising costs of public pensions by a durable reduction in the public debt through fiscal consolidation. 


\section{Box 8. Health Care: The Present Dutch System}

The health care ayatem is characterized by good health results, a high degree of acoosibility, and atrong antisfaction with services-but only an average degree of efficiency, and excessive expenditure on cortain components measures such as long-torm care costa and medicines prices. The system has undergone a series of reforms (both macro-constraints and structural) to control the growth in expenditure and move toward a more market-oriented system, with a shift in emphasis from direct controls to financial inoentives. The following describes the present health care system:

Public health insurers

- In the cure sector, some 60 pereent of the population are insured with public houlth ineurers, with the remainder privately insured. - A riak structure compenation asutem is used for financing the insurers from public funds. The government provides a centralized budget to cach insurer which roflects the projectod health costs of its elients; projected costs ars based on patient profiles, which use four characteristics - age, gender, region, and health tutus.

- It is expected that the budget provided to the insurer may not cover all costs. Ineurers may thenefore charge their clients additional nominal premia, which may vary among insurers. These premia are expected to encourage competition among insurers.

\section{Ambulatory care}

- The general practitioner (GP) plays the role of the gatekeoper in that the patient's first contact with the aystem is through the GP, who provides a reforral to a hospital or speoialist, if necessary. Public insurers negotiate with the GP to discourage excessive use of hospitals. - Each publicly-insured individual registers with only one GP, who is paid on an annual capitation basis. Privately-insured patients, however, pay on a per visit basis.

- Doctors' profles are not used in a systematic fashion.

- In 1997, co-payments were introduced, representing a tradeoff between sccessibility and cost control. With some exceptions, publiclyinsured petients must now pay 20 percent of treatment costs, up to a maximum of $f .200$ por family per year.

\section{Hospitals}

- Although hoepitals are prtvate, non-profit orcaniantions, eech hoepital is subject to a government-epecified ex ante annual budget. Since it is ultimately insurers who pay for the hospitals' costs, volume-based aproments are made betwoen the insurers and the hospitals. However, if the hospital spends more than its budget, the insurer automatically pays its patients' costs. Thus, hospitals do not really face a hard ex post budget constraint. The system currently suffers from some overcapactty.

- With wages of staff comprising about 75 percent of hospitals' costs, the government has sometimes employed wage controls on hospital staff (in particular, nurses) to hold down costs.

- In the past, specialists were paid on a fee-for-service basis, but this system was changed in 1994. Now specialists are to negotiate contracts with the hospitals, which receive separate lump sums based on each hospital's historical use of specialists.

$\bullet$

Medicines

- Drug price reform was initiated in mid-1996 with pasage of the Law on Prices of Medicines. Acoording to this law, a price celling on each medicine is established by averaging the prices in four comparator countries: Germany, Belgium, France, and the United Kingdom. - There has been a traditionally low predilection (apparently more of a culturally-based preference rather than a response to the high prices) for using prescription medicines in the Netherlands.

\section{Long-term care}

- In the care sector, public insurance coverage is 100 percent (which avoids the issue of adverse selection), and there is virtually no competition. The introduction of a more market-oriented approach has received some consideration.

- At present, there is excessive use of nursing homes and other residential facilities for the elderly, relative to other EU countries. There is not a strong home care support system.

Dental care

- The provision of dental care has been privatized since 1995, with the exception that all are publicly-insured up to age 17.

Health care expenditure as a whole, at about 9 percent of GDP, is in line with other EU countries. However, if an adjustment to these figures were made to account for the relative youth of the Dutch population, the situation would appear more serious. Indeed, costs as a percentage of GDP are expected to climb substantially as the population ages, with an acceleration in expenditure expected to occur around 2010 and the demographic shock reaching a peak around 2040. 


\section{Box 9. Generational Accounting in the Netherlands}

The CPB has assessed the intergenerational effects of fiscal policy through the use of generational accounting. This exercise, in a deep sense, throws light on fiscal sustainability and is, in many ways, complementary to traditional analyses of debt dynamics.

\section{Standard method}

The standard approach (Variant 1) extrapolates the policies in the projected budget for 1998, but ignores prospective changes in the economic environment which could significantly affect the lifecycle pattern of taxes. With this set of basic static assumptions, the generational imbalance (i.e., the difference in the net tax burden of future generations relative to the newly born generation) amounts to some 17 percent of lifetime income, raising questions about the sustainability of current fiscal policy to the extent that it benefits the current youngest generation at the expense of future generations. $^{1}$

\section{Other variants}

Several other variants, which incorporate additional assumptions about the evolving economic environment, were also examined (note that each successive variant is cumulative in that it includes the assumptions of the previous variant):

- Variant 2 assumes an increase in the rate of labor force participation, reflecting higher participation by women and the effects of tighter the eligibility for disability benefits. The resultant widening of the tax base reduces the generational imbalance to only $61 / 2$ percent of lifetime income.

- Variant 3 adds the assumption of rising private pension incomes, which also strengthen the tax base and thereby reduce the generational imbalance even further to some $3 \frac{1}{4}$ percent of lifetime income. However, the projected benefits from a rise in private pension incomes could be reversed if adverse circumstances require that future generations pay higher pension premiums in order to finance these defined-benefit schemes.

- Variant 4 projects a flattening of the age-earnings profile, reflecting both the future relative scarcity of younger workers as well as the growing importance of market forces which could create a tighter linkage of wages to productivity. In contrast to the two previous variants, this assumption reverses the improvement in the generational imbalance, which rises marginally to some $53 / 4$ percent of lifetime income. Variant 4 is expected to be the most representative of the future intergenerational stance of current fiscal policies. ${ }^{2}$

Increases in labor force participation and private pension incomes should thus help to offset the burden imposed by the aging of the Dutch population. However, this assessment also illustrated that, factoring in an analysis of debt dynamics, a sustainable fiscal policy will require significant further fiscal consolidation over the medium term in order to finance age-related spending in the longer run. Moreover, in view of the sensitivity of the results to participation rates, it confirmed that policies targeted toward raising participation could be among the most effective in securing a sustainable fiscal position.

'The projected generational imbalances are quite sensitive to changes in the parametric assumptions. If the discount rate rises from the assumed 5 percent to 7 percent, for example, the generational imbalance, expressed as a percentage of lifetime income, increases to some 23 percent.

2 If the benefits of government purchases are assigned to the generations, the generational imbalance becomes 
141. Appendix II illustrates that the adjustment can be greatly facilitated by labor market policies aimed at raising the labor force participation rate from its currently very low level. Increased labor participation, by partly offsetting the labor supply shock entailed by ageing, limits the demographics-related increase in the expenditure ratio, while at the same time ensuring larger interest savings from a faster fall in the debt ratio. While raising labor force participation would be important for mitigating the impact of adverse demographics in almost all industrial countries, its beneficial impact can be expected to be stronger in the case of the Netherlands. This is mainly because, in contrast to other countries, basic pension (AOW) benefits in the Netherlands are not predicated on a minimum work history on the part of the beneficiary -in that sense the AOW scheme should be viewed as a general old age benefit rather than as a pension; hence, there is no partial offset from higher basic pension liabilities to the fiscal benefit of higher participation.

142. These considerations would suggest that the need to re-balance labor market policies in favor of policies aimed at improving the supply side of the labor market, which was argued above on medium-term grounds, is considerably strengthened once the implications of longerterm demographic developments are taken into account. Starting from a situation of near-zero wage gap, the supply-side constraint will increasingly become the binding constraint on the labor market as the demographic shock sets in. In such a setting, with market forces exerting upward pressure on the equilibrium real wage, focussing on policies aimed at lowering labor costs while failing to address the supply constraint cannot be expected to have much of an impact on employment-indeed such a policy mix would eventually necessitate a substantial increase in the tax and premium burden to ensure the sustainability of the fiscal position.

143. More broadly, structural product market policies could usefully complement policies to raise labor force participation in strengthening the supply side of the economy in the face of the demographic shock. In this regard, the success of recent initiatives aimed at the liberalization and deregulation of product markets could be of key importance. While quantifying the relevant effects is particularly difficult, there is some empirical evidence that the impact of product market reform on an economy's growth rate of total factor productivity can be substantial. ${ }^{44}$

144. These considerations underscore the case for pressing forward with reforms in the labor and product markets, and illustrate that, in the future as in the past, a virtuous circle can be achieved in terms of economic growth, employment, and fiscal sustainability. It should be emphasized, however, that while policies to improve the supply side of labor and product markets can certainly facilitate accommodation of the demographic shock, they should not be viewed as substitutes for early deficit and debt reduction. Indeed, in line with the projections in Appendix II, continuing fiscal consolidation over the next few years appears crucial to prevent a future rise in the tax and premium burden, while ensuring fiscal sustainability.

\footnotetext{
${ }^{44}$ See, for example, Koedijk and Kremers (1996), for a cross-country analysis of OECD countries.
} 


\section{The Wage Gap: A Cobb-Douglas Specification}

1. This appendix summarizes some technical aspects of the Cobb-Douglas specification relevant to wage gap estimation. Consider a constant returns to scale, Cobb-Douglas production function, according to which output $(\mathrm{Y})$ depends on two factors of production, labor $(\mathrm{L})$ and capital $(\mathrm{K})$, as follows:

$\log (Y)=A(t)+\alpha \log (K)+(1-\alpha) \log (L)$

2. With firms employing labor up to the point where the real wage $(w / p)$ equals its marginal product, it is straightforward to show that the equilibrium labor income share $\left(\mathrm{S}_{\mathrm{L}}{ }\right)$ is equal to the technological parameter $(1-\alpha)$ :

$S_{L} \cdot=w L / p=(1-\alpha)$

3. This simple relationship suggests that inter-country differences in technology, or indeed differences in sectoral compositions, can fully justify differences in labor shares across countries, without in any way signifying that one country is further away from labor market equilibrium than another.

4. The production function described by equation (1) can be equivalently expressed in terms of rates of change of the underlying variables, denoted by $\mathrm{d}($.$) , and can be efficiently$ estimated by ordinary least squares, after imposing the restriction that the coefficients of the capital and labor terms sum to 1 . The estimation results for the Netherlands, over the period 1975-1996, ${ }^{1}$ were as follows (t-statistics in parenthesis):

$d(Y)=0.792+0.356 d(K)+0.644 d(L)$

$\mathrm{R}^{2}=0.22 \quad \mathrm{SE}=1.429 \quad \mathrm{~F}(1,19)=5.5 \quad \mathrm{DW}=1.9$

5. The estimation results suggest an equilibrium labor income share of 64 percent. On the basis of this estimate, a wage gap estimate can be obtained as the difference between the actual labor income share from its equilibrium level.

'The sample was restricted to post-1975 observations in order to correct for the declining importance of the natural gas sector over time. 


\section{Medium- and Long-Term Scenarios}

1. This appendix presents three alternative long-term fiscal scenarios to illustrate possible developments in the public finances up to the year 2040 (Charts 26 and 26a). The scenarios suggest how the impending demographic shock to the public finances could to a large extent be offset by early fiscal adjustment, as well as by reforms to foster an increase in the participation rate.

2. In the baseline scenario (Scenario A) the general government balance improves only slightly, to a deficit of 1 percent of GDP, in 2002; thereafter it remains constant. From 2003 onwards, the impact of the demographic transition starts gradually to be felt, with health care and pension expenditure rising by 0.2 percentage points a year, cumulating in a total increase of some $71 / 2$ percentage points in 2040. Other primary expenditure as a percentage of GDP decreases slightly until 2005, and thereafter remains constant. However, with overall expenditure rising, keeping the deficit constant - within limits implied by the Stability and Growth Pact and to ensure an acceptable trajectory for the debt ratio-requires an increase in the tax burden: revenues gradually increase, and by 2040 are up by 6 percentage point of GDP.

3. In a stronger fiscal policy scenario (Scenario B) the general government budget is brought into a surplus of 1 percent of GDP in 2002, and thereafter for a while remains constant. The impact of the demographic shock on health-care and pension expenditure is the same as in the baseline scenario, and other primary expenditure as a percentage of GDP is assumed to remain constant from 2005 onwards as well. However, as the government debt is lower in this scenario, so are interest payments. When, as a result of the demographic shock, overall expenditure starts to rise, this is initially offset by a reduction in the budget balance. Only when the deficit reaches 1 percent of GDP, are revenues increased. As a result, in the stronger fiscal policy scenario, revenues need to be raised by less, and later, demonstrating the benefits of early fiscal adjustment.

4. In the third scenario (scenario $C$ ), the stronger fiscal policy of scenario $B$ is accompanied by an increase in the participation rate as well as some additional pension and health care reforms. The impact of the increase of the participation rate and the pension and health care reforms is twofold. First, during the period of the participation rate increase (2005-2025), annual GDP growth is assumed to be $1 / 4$ percent higher. Of course, this is only a temporary effect; after 2025, the growth rate is the same as in the two other scenarios-although the level of GDP is higher. Second, the path of primary expenditure is slightly lower. With stronger growth and lower expenditure, the revenue ratio can decline for a longer period and subsequently rise by less. In this scenario, the revenue ratio in 2040 is about 6 percentage points lower than in the baseline scenario, and 2 percentage points lower than in the stronger fiscal policy scenario. 
CHART 26

NETHERLANDS

Long-Term Fiscal Scenarios

(In Percent of GDP)
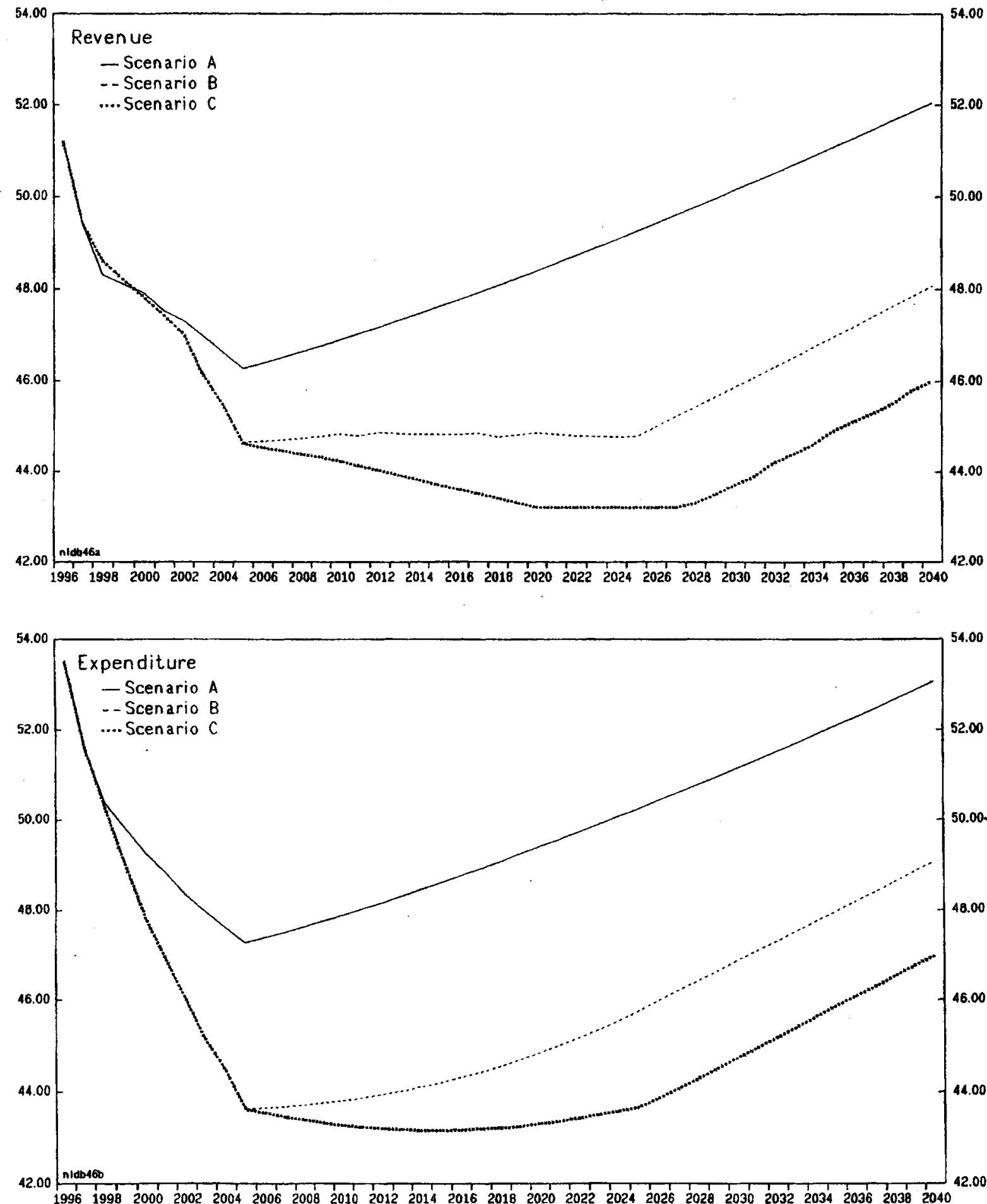

Source: Staff Calculations. 


\section{Long-Term Fiscal Scenarios - Continued}

(In Percent of GDP)
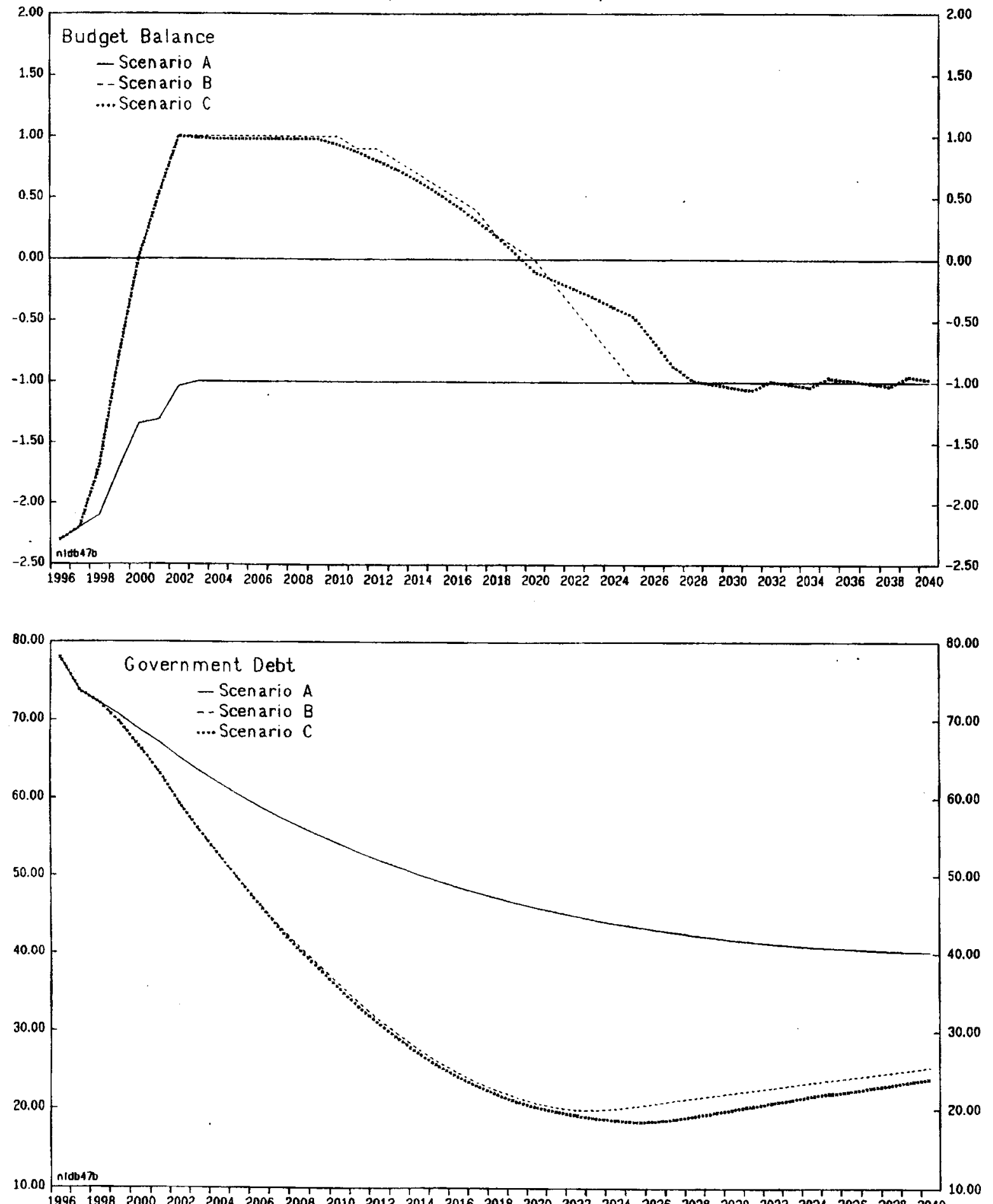

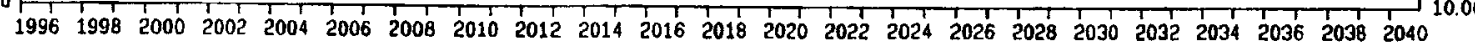
Source: Staff Calculations. 


\section{References}

Artus, J. (1984), “The Disequilibrium Real Wage Hypothesis: An Empirical Evaluation", I.M.F. Staff Papers.

Central Planning Bureau (1992), FKSEC: A Macroeconometric Model for the Netherlands, Stenfert Kroese Uitgevers, Leiden/Antwerpen.

Centraal Planbureau (1991), De Werrkgelegenheid in de Jaren Tachtig, Werkdocument No. 41, Den Haag.

Den Dunnen, E. (1985), Instruments of Money Market and Foreign Exchange Market Policy in the Netherlands, Monetary Monographs No. 3, de Nederlandsche Bank N.V. I Martinus Nijhoff Publishers, Dordrecht.

Den Hartog, H., and H.S. Tjan (1974), Investeringen, Lonen, Prijzen en Arbeidsplaatsen, Central Planning Bureau Occasional Paper No. 2.

Don, H. (1996), “Tax Reform and Job Creation”, CPB Report, No. 4.

Kmenta, J. (1967), "On Estimation of the CES Production Function”, International Economic Review, Vol.8, June.

Koedijk, K. And J. Kremers (1996), "Market Opening, Regulation and Growth in Europe", Economic Policy, October.

Lipschitz, L. and S. M. Schadler (1984), "Relative Prices, Real Wages, and Macroeconomic Policies: Some Evidence from Manufacturing in Japan and the United Kingdom", I.M.F. Staff Papers.

Moons, A. C. and O. J. C. Cornielje (1993), "Loonmatiging en Overlegeconomie", Economisch Statistische Berichten, No. 3934, October 27.

Oudshoorn, C. (1993a), "Marktwerking in het Sociaal-Economisch Bestel", Economisch Statistische Berichten, No. 3931, October 6.

Oudshoorn, C. (1993b), 'Naschrift", Economisch Statistische Berichten, No. 3934, October 27.

Van Ark, B., J. de Haan, and H. J. de Jong (1996), "Characteristics of Economic Growth in the Netherlands during the Post-War Period", in N. Crafts and G. Toniolo (eds.), Economic growth in Europe since 1945, Cambridge University Press, pp. 290-328. 
Table 4. Netherlands: Aggregate Demand

\begin{tabular}{|c|c|c|c|c|c|c|c|c|c|}
\hline & \multicolumn{2}{|l|}{1995} & \multirow{3}{*}{1990} & \multirow{3}{*}{1991} & \multirow[b]{2}{*}{1992} & \multirow[b]{2}{*}{1993} & \multirow[b]{2}{*}{1994} & \multirow[b]{2}{*}{1995} & \multirow{3}{*}{1996} \\
\hline & $\begin{array}{l}\text { In billions } \\
\text { of current }\end{array}$ & $\begin{array}{c}\text { As } \\
\text { percent }\end{array}$ & & & & & & & \\
\hline & guilders & of GDP & & & Volum & e chang & 8, in $p$ & rcent & \\
\hline Public consumption & 90.9 & 14.3 & 1.6 & 1.5 & 1.7 & 1.5 & 0.2 & 0.6 & 0.8 \\
\hline \multicolumn{10}{|l|}{ Gross fixed capital } \\
\hline formation & 123.3 & 19.4 & 1.6 & 0.2 & 0.6 & -2.8 & 1.6 & 6.7 & 4.8 \\
\hline Public sector & 17.0 & 2.7 & 6.8 & 2.4 & 7.4 & -1.1 & 2.8 & 2.2 & 1.5 \\
\hline Private sector & 106.3 & 16.7 & 0.9 & -0.1 & -0.4 & -3.1 & 1.4 & 7.5 & 5.3 \\
\hline Residential & 33.1 & 5.2 & -2.5 & -5.4 & 6.4 & -0.3 & 6.3 & 1.6 & -0.2 \\
\hline Final domestic demand & 594.7 & 93.7 & 3.2 & 2.2 & 2.0 & 0.3 & 1.8 & 2.8 & 3.0 \\
\hline Stockbuilding $1 /$ & -0.2 & -- & 0.2 & -0.3 & -0.4 & -1.3 & 1.3 & -0.5 & -0.4 \\
\hline Total domestic demand & 594.5 & 93.6 & 3.5 & 1.9 & 1.6 & -1.1 & 3.1 & 2.2 & 2.6 \\
\hline \multicolumn{10}{|l|}{ Exports of goods and } \\
\hline nonfactor services & 338.3 & 53.3 & 5.3 & 4.7 & 2.9 & 1.5 & 6.7 & 6.9 & 3.8 \\
\hline \multicolumn{10}{|l|}{ Imports of goods and } \\
\hline nonfactor services & 297.8 & 46.9 & 4.2 & 4.1 & 2.1 & -2.1 & 6.5 & 7.7 & 3.7 \\
\hline \multicolumn{10}{|c|}{ Foreign balance on goods and } \\
\hline Gross domestic product & 635.0 & 100.0 & 4.1 & 2.3 & 2.0 & 0.8 & 3.4 & 2.1 & 2.7 \\
\hline \multicolumn{10}{|l|}{ Memorandum itoms: } \\
\hline Gross national product & 636.1 & 100.2 & 3.9 & 2.3 & 1.9 & 1.0 & 3.8 & 2.0 & $\cdots$ \\
\hline Net national income & 562.5 & 88.6 & 4.4 & 1.9 & 1.1 & 0.9 & 3.8 & 2.3 & $\cdots$ \\
\hline
\end{tabular}

Sources: Central Bureau of Statistics, Nationale Rekeningen 1995; Central Planning Bureau, Central Economic Plan 1997; and staff estimates.

1/ Change as a percent of previous year's GDP. 
Table 5. Netherlands: Personal Income, Consumption, and Household Saving

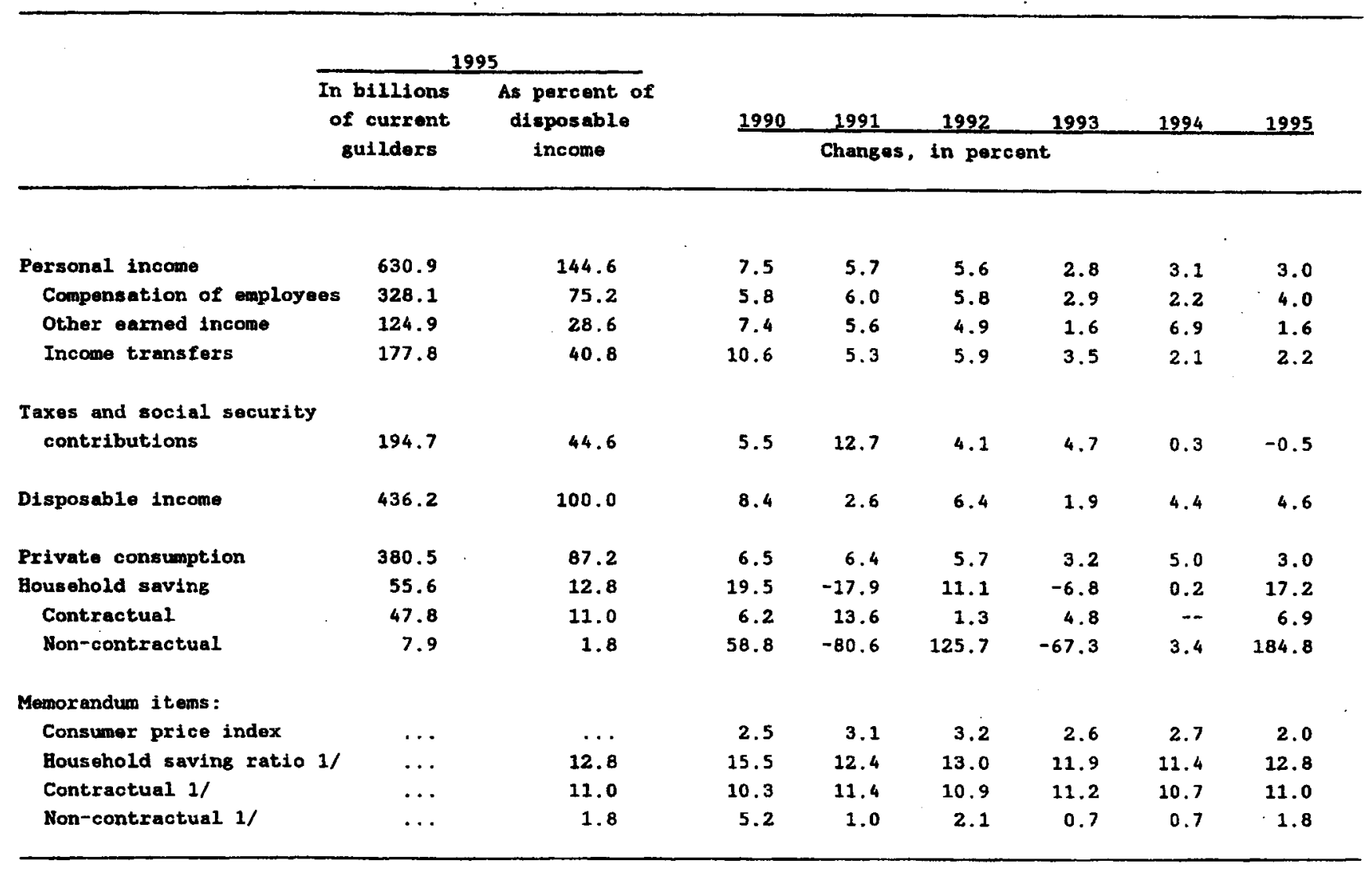

Source: Central Bureau of Statistics, Nationale Rokeningen 1995.

1/ As a percentage of disposable income. 
Table 6. Netherlands: Private Consumption of Goods and Services

\begin{tabular}{|c|c|c|c|c|c|c|c|c|c|}
\hline & \multicolumn{2}{|c|}{1995} & \multirow[b]{2}{*}{1990} & \multirow[b]{2}{*}{1991} & \multirow[b]{2}{*}{1992} & \multirow[b]{2}{*}{1993} & & \multirow[b]{2}{*}{1995} & \multirow[b]{2}{*}{1996} \\
\hline & $\begin{array}{l}\text { In billions } \\
\text { of guilders }\end{array}$ & $\begin{array}{l}\text { As percent } \\
\text { of total }\end{array}$ & & & & & $\frac{1994}{\text { ent }}$ & & \\
\hline \multicolumn{10}{|l|}{ Food, beverages, and } \\
\hline tobacco & 54.4 & 14.3 & 2.3 & 0.6 & 2.7 & -0.3 & 1.5 & 1.2 & 2.5 \\
\hline Durable goods & 69.9 & 18.4 & 8.6 & 4.8 & 0.8 & -1.6 & 1.5 & 0.7 & 4.2 \\
\hline $\begin{array}{l}\text { Other soods and services } \\
\text { Of which: }\end{array}$ & 250.6 & 65.9 & 3.4 & 3.4 & 3.2 & 2.1 & 2.7 & 2.4 & 2.9 \\
\hline $\begin{array}{l}\text { Housing } \\
\text { Hoating, lighting, }\end{array}$ & 58.7 & 15.4 & 4.2 & 2.9 & 2.8 & 3.0 & 2.7 & 3.1 & 3.1 \\
\hline water & 12.7 & 3.3 & -0.1 & 8.7 & -3.2 & 4.1 & -1.6 & 2.0 & ... \\
\hline Health care services & 39.6 & 10.4 & 2.2 & 3.0 & 3.2 & 1.4 & 1.0 & 1.9 & $\cdots$ \\
\hline \multicolumn{10}{|l|}{ Domestic private } \\
\hline consumption & 374.9 & 98.5 & 4.4 & 3.2 & 2.6 & 1.0 & 2.1 & 1.9 & $\cdots$ \\
\hline \multicolumn{10}{|l|}{ Plus : consumption abroad by } \\
\hline $\begin{array}{l}\text { Minus: consumption by } \\
\text { nonresidents in the }\end{array}$ & & & & & & & & 0.0 & $\cdot$ \\
\hline Netherlands & 8.4 & 2.2 & -3.5 & 20.9 & 9.4 & -6.4 & -3.2 & 0.7 & .. \\
\hline Total private consumption & 380.5 & 100.0 & 4.2 & 3.1 & 2.5 & 1.0 & 2.2 & 2.1 & 3.1 \\
\hline \multicolumn{10}{|l|}{ Memorandum item: } \\
\hline Population growth & $\ldots$ & .. & 0.7 & 0.8 & 0.8 & 0.7 & 0.6 & 0.5 & 0.4 \\
\hline
\end{tabular}

Sources: Central Bureau of Statistics. Nationale Rekeningen 1995; Central Planning Bureau, Central Economic Plan 1997; and staff estimates. 
Table 7. Netherlands: Saving and Investment

\begin{tabular}{|c|c|c|c|c|c|c|}
\hline & 1990 & 1991 & 1992 & 1993 & 1994 & 1995 \\
\hline & \multicolumn{6}{|c|}{ (In billions of guilders) } \\
\hline Gross saving & 134.2 & 134.5 & 134.2 & 136.1 & 150.0 & 156.2 \\
\hline Households & 55.7 & 45.8 & 50.8 & 47.4 & 47.5 & 55.6 \\
\hline Contractual & 37.1 & 42.1 & 42.7 & 44.7 & 44.7 & 47.8 \\
\hline Non-contractual & 18.6 & 3.6 & 8.2 & 2.7 & 2.8 & 7.9 \\
\hline Business sector & 86.8 & 87.1 & 88.7 & 90.8 & 105.7 & 107.1 \\
\hline Public sector & -8.3 & 1.6 & -5.3 & -2.1 & -3.2 & -6.5 \\
\hline Gross investment & 114.5 & 115.8 & 116.5 & 107.8 & 118.1 & 123.1 \\
\hline Business sector & 100.8 & 101.4 & 100.7 & 92.1 & 101.7 & 106.2 \\
\hline Stocks & 6,5 & 5.3 & 3.1 & -3.8 & 3.5 & -0.2 \\
\hline Fixed investment & 67.2 & 69.8 & 68.8 & 66.6 & 66.5 & 73.3 \\
\hline Residential construction & 27.0 & 26.2 & 28.8 & 29.2 & 31.6 & 33.1 \\
\hline Public sector & 13.7 & 14.4 & 15.7 & 15.8 & 16.4 & 17.0 \\
\hline \multirow[t]{2}{*}{ Curront account } & 19.8 & 18.7 & 17.8 & 28.3 & 31.9 & 33.1 \\
\hline & \multicolumn{6}{|c|}{ (In percent of GNP) } \\
\hline Gross seving & 26.0 & 24.8 & 23.8 & 23.4 & 24.4 & 24.6 \\
\hline Households & 10.8 & 8.4 & 9.0 & 8.2 & 7.7 & 8.7 \\
\hline Contractual & 7.2 & 7.8 & 7.6 & 7.7 & 7.3 & 7.5 \\
\hline Non-contractual & 3.6 & 0.7 & 1.4 & 0.5 & 0.4 & 1.2 \\
\hline Business sector & 16.8 & 16.1 & 15.7 & 15.6 & 17.2 & 16.8 . \\
\hline Public sector & -1.6 & 0.3 & -0.9 & -0.4 & -0.5 & -1.0 \\
\hline Gros: investment & 22.2 & 21.4 & 20.7 & 18.6 & 19.2 & 19.4 \\
\hline Business sector & 19.5 & 18.7 & 17.9 & 15.8 & 16.5 & 16.7 \\
\hline Stocks & 1.3 & 1.0 & 0.6 & -0.6 & 0.6 & -- \\
\hline Fixed Investmont & 13.0 & 12.9 & 12.2 & 11.5 & 10.8 & 11.5 \\
\hline Residential construction & 5.2 & 4.8 & 5.1 & 5.0 & 5.1 & 5.2 \\
\hline Public sector & 2.7 & 2.7 & 2.8 & 2.7 & 2.7 & 2.7 \\
\hline \multirow[t]{2}{*}{ Current account } & 3.8 & 3.5 & 3.2 & 4.9 & 5.2 & 5.2 \\
\hline & \multicolumn{6}{|c|}{ (In percent of NNI) } \\
\hline Net saving & 16.3 & 15.0 & 13.7 & 13.2 & 14.5 & 14.7 \\
\hline Households & 12.2 & 9.6 & 10.2 & 9.2 & 8.7 & 9.9 \\
\hline Business sector & 6.9 & 6.0 & 5.5 & 5.3 & 7.3 & 6.9 \\
\hline Public sector & -2.7 & -0.6 & -2.0 & -1.3 & -1.5 & -2.1 \\
\hline Het investment $1 /$ & 12.0 & 11.1 & 10.2 & 7.7 & 8.7 & 8.8 \\
\hline Business sector & 9.9 & 9.0 & 7.9 & 5.5 & 6.5 & 6.7 \\
\hline Public sector & 2.1 & 2.1 & 2.2 & 2.1 & 2.1 & 2.1 \\
\hline
\end{tabular}

Source: Central Bureau of Statistics, Nationale Rekeningen 1995.

1/ Excluding residential construction. 
Table 8. Netherlands: Gross Fixed Investment

\begin{tabular}{|c|c|c|c|c|c|c|c|c|}
\hline & \multicolumn{2}{|c|}{1995} & \multirow[b]{2}{*}{1990} & \multirow[b]{2}{*}{$\frac{1991}{\text { Volume }}$} & \multirow[b]{2}{*}{1992} & \multirow[b]{2}{*}{1993} & \multirow[b]{2}{*}{1994} & \multirow[b]{2}{*}{1995} \\
\hline & $\begin{array}{l}\text { In blllions } \\
\text { of currrent } \\
\text { guilders }\end{array}$ & $\begin{array}{l}\text { As per- } \\
\text { cent of } \\
\text { total }\end{array}$ & & & & & & \\
\hline Total & 127.2 & 100.0 & 2.2 & -0.2 & 1.0 & -2.5 & 1.5 & 6.9 \\
\hline \multicolumn{9}{|l|}{ By type: } \\
\hline Residential construction & 33.1 & 26.0 & -2.5 & -5.4 & 6.4 & -0.3 & 6.3 & 1.6 \\
\hline Nonresidential buildings & 17.9 & 14.1 & 3.0 & 5.4 & -6.2 & -12.7 & -3.6 & 1.7 \\
\hline Infrastructural works & 14.8 & 11.7 & 1.8 & 3.9 & 6.9 & 3.3 & -0.7 & 2.0 \\
\hline Transport equipmont & 14.5 & 11.4 & 4.6 & 5.3 & -2.1 & -11.8 & 5.0 & 9.5 \\
\hline Machinery and quipment & 42.4 & 33.3 & 5.2 & -2.2 & -0.1 & 1.2 & -1.8 & 15.2 \\
\hline Other & 4.4 & 3.5 & -3.1 & -1.8 & 5.7 & 9.8 & 20.4 & -6.7 \\
\hline \multicolumn{9}{|l|}{ By destination: } \\
\hline \multicolumn{9}{|l|}{ Agriculture and } \\
\hline fishories & 4.5 & 3.6 & 4.1 & -3.4 & -5.9 & -18.9 & -2.4 & 2.0 \\
\hline Industry & 26.6 & 20.9 & 1.2 & -1.5 & -5.1 & 4.8 & -7.0 & 14.8 \\
\hline Services & 96.0 & 75.5 & 2.4 & 0.4 & 3.1 & -3.6 & 4.1 & 4.9 \\
\hline \multicolumn{9}{|l|}{ Wholesale and } \\
\hline retail trade & 11.6 & 9.1 & 1.5 & 8.5 & -1.6 & -1.6 & -2.0 & 8.9 \\
\hline \multicolumn{9}{|l|}{ Transport and } \\
\hline communication & 13.3 & 10.5 & -0.3 & 3.6 & 1.4 & -18.9 & 15.9 & 7.8 \\
\hline Other & 71.1 & 55.9 & 3.1 & -1.6 & 4.4 & -0.7 & 3.1 & 3.6 \\
\hline
\end{tabular}

Source: Central Bureau of Statistics, Nationale Rekeningen 1995. 
Table 9. Netherlands: Sectoral Value Added

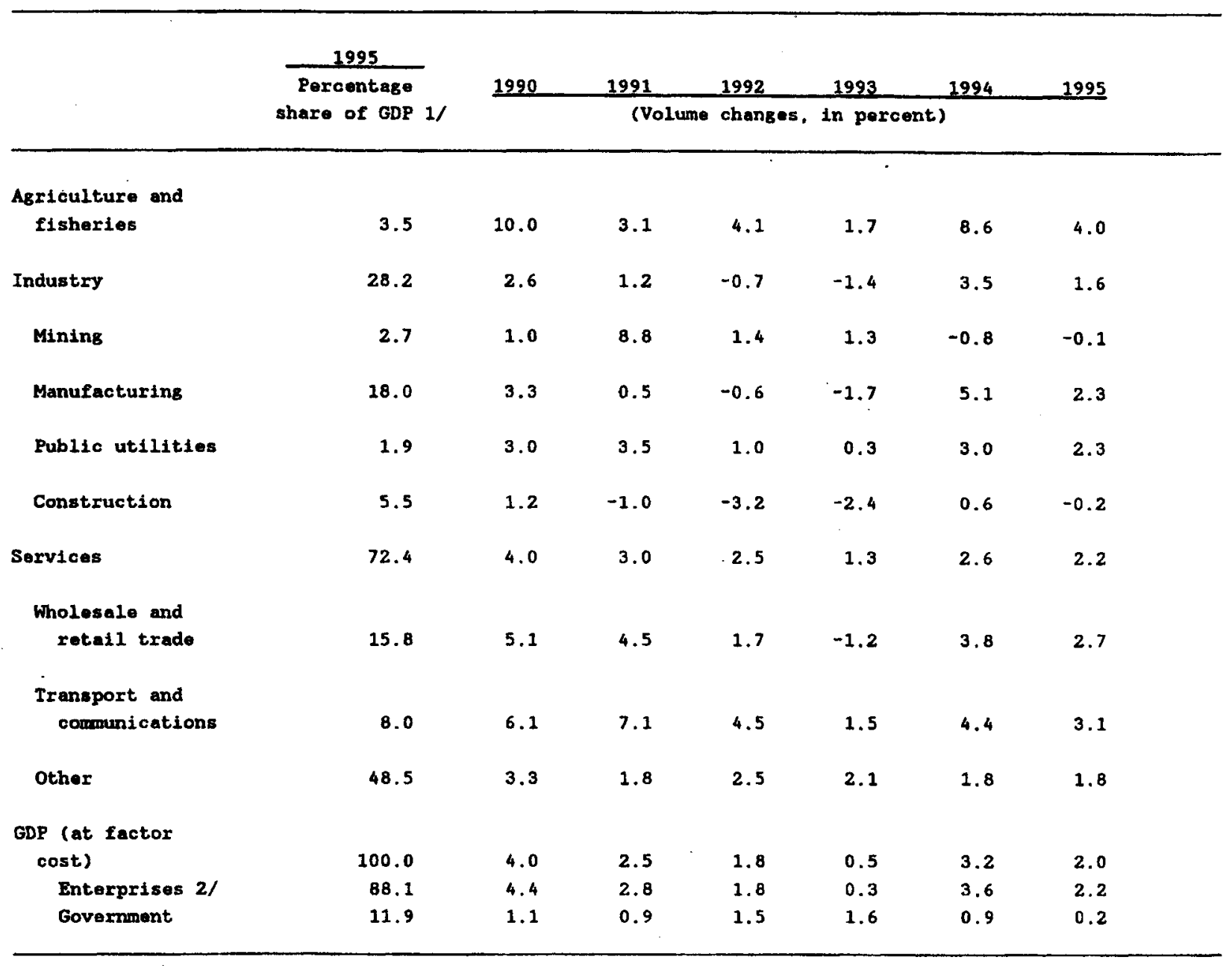

Sources: Central Bureau of Statistics, Nationale Rekeningen 1995; and staff calculations.

1/ The sum of pexcentage shares exceeds 100 because the imputed value of intermediary banking services 18 excluded from GDP but not from the value added of sectors.

2f Comprises private, public, and semi-public enterprises. 
Table 1C Netherlands: Selected Labor Market Indicators

(Changes, in percent)

\begin{tabular}{|c|c|c|c|c|c|c|c|}
\hline . & 1990 & 1991 & 1992 & 1993 & 1994 & 1995 & 1996 \\
\hline & \multicolumn{7}{|c|}{ (In thousands) } \\
\hline Population 15-64 & 10,305 & 10,372 & 10,434 & 10,490 & 10,535 & 10,569 & 10,603 \\
\hline Labor force & 5,993 & 6,066 & 6,182 & 6,246 & 6,315 & 6,409 & 6,495 \\
\hline Employment (persons) & 6,240 & 6,538 & 6,451 & 6,459 & 6,504 & 6,630 & 6,782 \\
\hline Employment (persons $>12$ hours/week) & 5,574 & 5,666 & 5,771 & 5,765 & 5,768 & 5,876 & 6,001 \\
\hline Employment (full-time equivalents) & 5,203 & 5,273 & 5,328 & 5,323 & 5,330 & 5,433 & 5,536 \\
\hline Government & 700 & 692 & 686 & 684 & 673 & 659 & 650 \\
\hline Private sector & 4,503 & 4,581 & 4,642 & 4,639 & 4,657 & 4,774 & 4,886 \\
\hline Unemployment & 419 & 400 & 411 & 481 & 547 & 533 & 494 \\
\hline Unemployment benefits recipients & 575 & 563 & 587 & 664 & 777 & 789 & 785 \\
\hline \multirow[t]{2}{*}{ Vacancies } & 115 & 98 & 71 & 41 & 41 & 55 & $\ldots$ \\
\hline & \multicolumn{7}{|c|}{ (Changes, in percent) } \\
\hline Population 15-64 & 0.6 & 0.7 & 0.6 & 0.5 & 0.4 & 0.3 & 0.3 \\
\hline Labor force & 1.6 & 1.2 & 1.9 & 1.0 & 1.1 & 1.5 & 1.3 \\
\hline Employment (persons) & 2.7 & 4.8 & -1.3 & 0.1 & 0.7 & 1.9. & 2.3 \\
\hline Employment (persons > 12 hours/week) & 2.4 & 1.7 & 1.9 & -0.1 & 0.1 & 1.9 & 2.1 \\
\hline Employment (full-time equivalents) & 2.3 & 1.3 & 1.0 & -0.1 & 0.1 & 1.9 & 1.9 \\
\hline Government & -0.4 & -1.1 & -0.9 & -0.3 & -1.6 & -2.1 & -1.4 \\
\hline \multirow[t]{2}{*}{ Private sector } & 2.8 & 1.7 & 1.3 & -0.1 & 0.4 & 2.5 & 2.3 \\
\hline & \multicolumn{7}{|c|}{ (In percent) } \\
\hline Participation rate (persons) & 58 & 58 & 59 & 59 & 60 & 60 & 61 \\
\hline Male & 73 & 73 & 73 & 73 & 73 & 74 & 75 \\
\hline Female & 42 & 43 & 44 & 45 & 45 & 46 & 47 \\
\hline Persons per full-time equivalent & 1.20 & 1.21 & 1.21 & 1.21 & 1.22 & 1.22 & 1.22 \\
\hline Unemployment rate & 7.0 & 6.6 & 6.6 & 7.7 & 8.7 & 8.3 & 7.6 \\
\hline \multicolumn{8}{|l|}{ Memorandum item: } \\
\hline Standardized unemployment rate & 6.0 & 5.5 & 5.4 & 6.6 & 7.6 & 7.1 & 6.6 \\
\hline
\end{tabular}

Sources: Central Planning Bureau, Central Economic Plan 1997; OECD, Economic Outlook.

1/ The labor force includes the employed with a job of at least 12 hours and the unemployed seeking employment of at least 12 hours per week. 
Table 11. Netherlands: Sectoral Distribution of Employment $1 /$

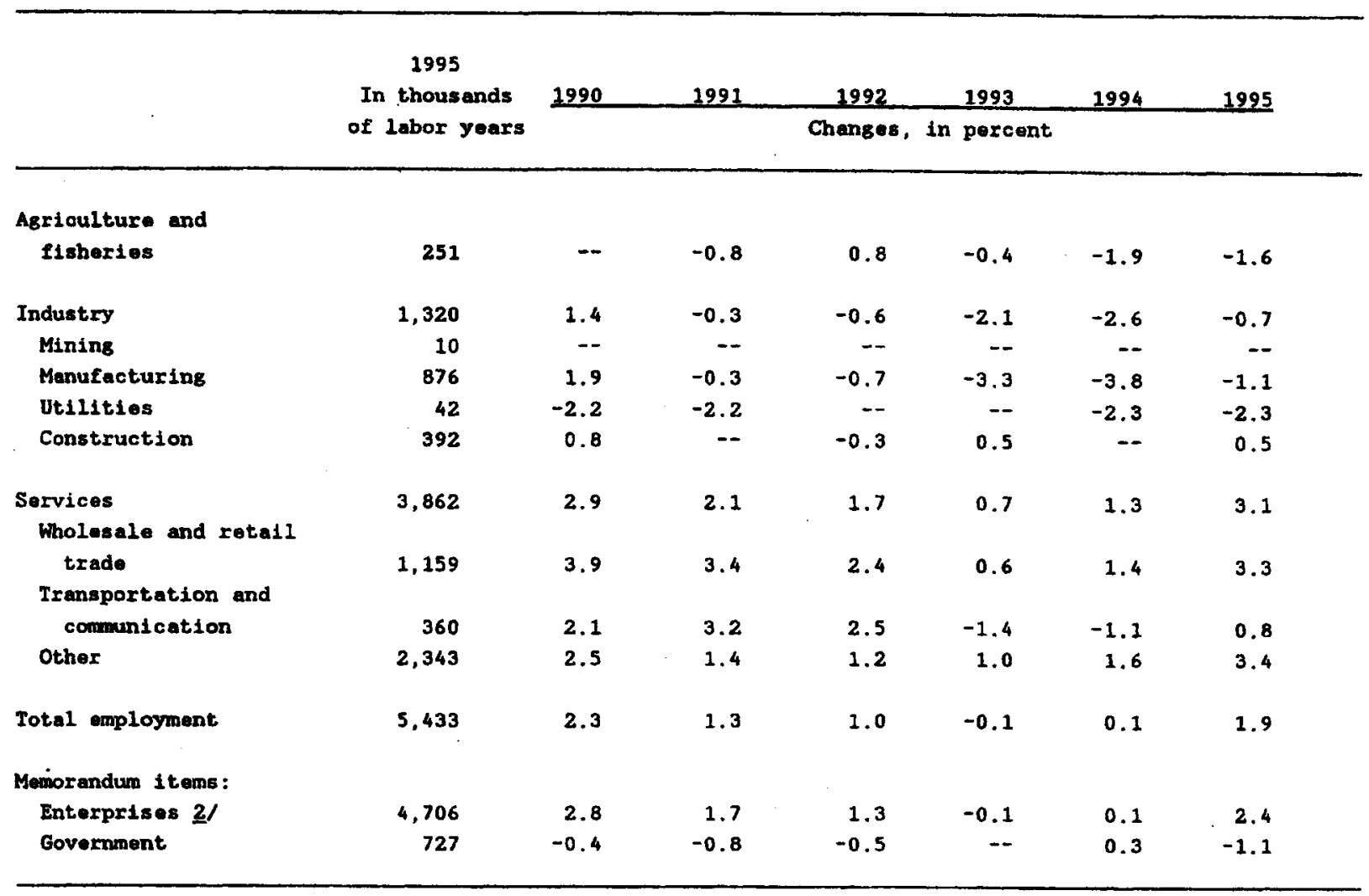

Source: Central Bureau of Statistics, Nationale Rekeningen 1995.

1/ In labor years.

2/ Comprises private, public, and semi-public enterprises. 
Table 12 Netherlands: Decomposition of the Increase in the Consumption Deflator

(Contributions to growth in percentage points)

\begin{tabular}{lrrrrrrr}
\hline & 1990 & 1991 & 1992 & 1993 & 1994 & 1995 & 1996 \\
& & & & & & & \\
\hline Imports & -0.1 & 0.4 & -- & -0.5 & 0.3 & -0.2 & 0.6 \\
$\quad$ Finished products & -- & 0.3 & 0.3 & -- & 0.2 & -0.2 & 0.2 \\
$\quad$ Raw materials and services & -0.3 & 0.1 & -0.1 & -0.3 & 0.2 & 0.1 & - \\
$\quad$ Energy & 0.2 & -- & -0.2 & -0.2 & -0.1 & -0.1 & 0.4 \\
& & & & & & & \\
Collective sector & 1.5 & 1.9 & 1.6 & 1.1 & 1.5 & 0.9 & 1.1 \\
$\quad$ Indirect taxes & 0.2 & 0.3 & 0.3 & 0.1 & 0.2 & 0.1 & 0.4 \\
$\quad$ Rent & 0.4 & 0.6 & 0.8 & 0.8 & 0.8 & - & 0.4 \\
$\quad$ Natural gas & 0.3 & 0.2 & -0.1 & -0.2 & 0.1 & 0.7 & - \\
$\quad$ Public services & 0.6 & 0.8 & 0.6 & 0.4 & 0.4 & 0.1 & 0.3 \\
Wage costs & 0.2 & 1.0 & 1.0 & 1.1 & -0.6 & 0.4 & 0.4 \\
Other 1/ & 0.8 & -0.2 & 0.6 & 0.3 & 1.7 & -0.4 & -0.5 \\
Total & 2.2 & 3.2 & 3.1 & 2.1 & 2.7 & 0.9 & 1.9 \\
Memorandum item: & & & & & & & \\
$\quad$ Consumer price index & 2.5 & 3.1 & 3.2 & 2.6 & 2.7 & 2.0 & 2.1 \\
& & & & & & & \\
\hline
\end{tabular}

Sources: Central Planning Bureau: Central Economic Plan 1997.

1/ Improvement in gross profit margins, including depration costs and net interest payments. 
Table 13 Netherlands: Selected Price Developments

(Changes, in percent)

\begin{tabular}{|c|c|c|c|c|c|c|c|}
\hline & 1990 & 1991 & 1992 & 1993 & 1994 & 1995 & 1996 \\
\hline GDP deflator & 2.3 & 2.7 & 2.3 & 1.9 & 2.0 & 1.4 & 1.3 \\
\hline Private consumption & 2.5 & 3.1 & 3.9 & 2.3 & 1.2 & 3.2 & 1.8 \\
\hline Public consumption & 2.2 & 3.2 & 3.1 & 2.1 & 2.7 & 0.9 & 0.5 \\
\hline Fixed investment & 2.1 & 2.1 & 2.0 & 1.3 & 1.1 & 0.9 & 1.3 \\
\hline Exports & -0.8 & 0.1 & -2.2 & -2.1 & 0.4 & 0.8 & 0.8 \\
\hline Imports & -1.3 & 0.4 & -1.4 & -2.3 & 0.6 & 0.2 & 1.3 \\
\hline Producer prices & 1.0 & 2.3 & 1.8 & 0.1 & 0.6 & 1.5 & 1.4 \\
\hline $\begin{array}{l}\text { Consumer price index } \\
\text { Of which: }\end{array}$ & 2.5 & 3.1 & 3.2 & 2.6 & 2.7 & 2.0 & 2.1 \\
\hline Food & $\ldots$ & $\ldots$ & 2.6 & 0.8 & 1.8 & 0.4 & 0.2 \\
\hline Clothing & $\cdots$ & $\ldots$ & 0.3 & 1.5 & -1.0 & -2.3 & 0.3 \\
\hline Rent and heating & $\ldots$ & $\ldots$ & 3.9 & 3.5 & 4.7 & 4.4 & 4.5 \\
\hline Furniture & $\ldots$ & $\ldots$ & 2.5 & 1.0 & 0.2 & 0.5 & 0.2 \\
\hline Medical treatment & $\ldots$ & $\ldots$ & 6.5 & 4.0 & 1.3 & 1.9 & 0.5 \\
\hline Transport and communication & $\cdots$ & $\ldots$ & 3.3 & 2.6 & 4.0 & 2.3 & 2.1 \\
\hline Recreation & $\ldots$ & $\ldots$ & 1.4 & 2.0 & 1.5 & - & 0.8 \\
\hline Other goods and services & $\ldots$ & $\ldots$ & 4.0 & 2.7 & 2.2 & 2.0 & 1.3 \\
\hline Taxes and government services & $\ldots$ & $\ldots$ & 8.6 & 10.2 & 7.1 & 3.8 & 4.5 \\
\hline
\end{tabular}

Sources: Central Bureau of Statistics, Nationale Rekeningen 1995, Online Databank; IMF, International Financial Statistics. 
Table 14 Netherlands: Compensation per Employee and Average Tax Wedge

(Changes, in percent)

\begin{tabular}{|c|c|c|c|c|c|c|c|}
\hline & 1990 & 1991 & 1992 & 1993 & 1994 & 1995 & 1996 \\
\hline \multicolumn{8}{|l|}{ Compensation per employee, private } \\
\hline sector & 3.0 & 4.4 & 4.1. & 2.9 & 2.4 & 1.3 & 0.5 \\
\hline Gross wage 1/ & 2.9 & 3.5 & 3.6 & 2.7 & 2.3 & 0.9 & 1.6 \\
\hline Contract wages & 2.9 & 3.5 & 4.3 & 3.1 & 1.8 & 1.4 & 1.6 \\
\hline Wage drift $1 /$ & -- & -- & -0.7 & -0.4 & 0.5 & -0.5 & -- \\
\hline Employer social security premiums $1 /$ & 0.1 & 0.9 & 0.5 & 0.2 & 0.1 & 0.4 & -1.1 \\
\hline $\begin{array}{l}\text { Compensation per employee, } \\
\text { enterprises } 2 /\end{array}$ & 3.2 & 4.4 & 4.1 & 3.2 & 2.3 & 1.4 & 0.6 \\
\hline \multicolumn{8}{|l|}{ Average tax wedge $3 /$} \\
\hline Minimum wage "plus" & 29 & 29 & 29 & 28 & 26 & 25 & 21 \\
\hline Modal wage & 41 & 42 & 42 & 42 & 42 & 41 & 41 \\
\hline 2x Modal wage & 51 & 52 & 54 & 54 & 53 & 53 & 53 \\
\hline
\end{tabular}

Sources: Central Planning Bureau, Central Economic Plan 1997.

1/ Contributions to growth.

2/ Comprises private, public, and semi-public enterprises.

$3 /$ Including social security contributions and supplementary pension premiums. 
Table 15 Netherlands: Labor Costs Indicators

(Changes, in percent)

\begin{tabular}{|c|c|c|c|c|c|c|c|}
\hline & 1990 & 1991 & 1992 & 1993 & 1994 & 1995 & 1996 \\
\hline & \multicolumn{5}{|c|}{ Enterprises } & \\
\hline Compensation per labor year & 3.5 & 4.6 & 4.2 & 2.6 & 2.0 & 1.8 & 1.0 \\
\hline Labor productivity & 1.6 & 1.0 & 0.5 & 0.5 & 3.4 & -0.2 & 0.7 \\
\hline Output (real) 1/ & 4.4 & 2.8 & 1.8 & 0.3 & 3.6 & 2.2 & 3.0 \\
\hline Employment (labor years) & 2.8 & 1.7 & 1.3 & -0.1 & 0.1 & 2.4 & 2.3 \\
\hline Unit labor costs & 1.9 & 3.6 & 3.7 & 2.2 & -1.4 & 1.9 & 0.3 \\
\hline \multirow[t]{2}{*}{ Value-added deflator $2 /$} & 2.0 & 2.5 & 1.7 & 1.7 & 1.8 & 0.3 & $\ldots$ \\
\hline & \multicolumn{7}{|c|}{ Manufacturing } \\
\hline Compensation per labor year & 2.7 & 4.6 & 4.8 & 3.3 & 2.7 & 2.8 & 1.5 \\
\hline Labor productivity & 1.4 & 0.8 & 0.2 & 1.6 & 9.3 & 3.5 & 2.2 \\
\hline Output (real) 1/ & 3.3 & 0.5 & -0.6 & -1.7 & 5.1 & 2.3 & 2.0 \\
\hline Employment & 1.9 & -0.3 & -0.7 & -3.3 & -3.8 & -1.1 & -0.2 \\
\hline Unit labor costs & 1.3 & 3.8 & 4.7 & 1.7 & -6.0 & -0.7 & -0.7 \\
\hline Value-added deflator $2 /$ & 1.3 & 1.5 & -0.1 & 1.4 & -1.3 & 1.9 & $\ldots$ \\
\hline Memorandum item: & & & & & & & \\
\hline Labor income share, enterprises 3/ & 80.7 & 82.4 & 84.5 & 86.2 & 83.1 & 83.9 . & 84.3 \\
\hline
\end{tabular}

Source: Central Bureau of Statistics, Nationale Rekeningen 1996; Central Planning Bureau, Central Economic Plan 1997, and staff estimates.

$1 /$ Gross value added at factor costs.

2/ Déflator of gross value added at factor costs.

3/ Percent share of labor compensation of employees and imputed labor income of self-employed in value added of enterprises, excluding mining, exploitation of dwellings, and government services. 
Table 16 Netherlands: Revenues and Expenditures of General Government:

\section{Economic Classification}

(In percent of GDP)

\begin{tabular}{lrrrrrr}
\hline & 1991 & 1992 & 1993 & 1994 & 1995 & 1996 \\
& & & & & & \\
\hline & & & & & & \\
& & & & & & \\
Revenues & 55.5 & 54.7 & 55.2 & 53.3 & 51.5 & 51.4 \\
Taxes and social security contributions & 47.5 & 46.5 & 46.8 & 44.8 & 43.7 & 44.4 \\
Nontax revenue & 8.0 & 8.2 & 8.4 & 8.5 & 7.8 & 7.0 \\
& & & & & & \\
Expenditures & 57.5 & 58.3 & 58.4 & 56.6 & 55.0 & 53.2 \\
Direct expenditures & 18.3 & 18.6 & 18.8 & 18.4 & 18.2 & 17.8 \\
$\quad$ Consumption & 15.5 & 15.8 & 16.0 & 15.6 & 15.5 & 15.1 \\
$\quad$ Wages & 9.6 & 9.8 & 10.0 & 9.7 & 9.7 & 9.4 \\
$\quad$ Goods/services & 5.9 & 6.0 & 6.0 & 5.9 & 5.8 & 5.7 \\
$\quad$ Investment & 2.8 & 2.8 & 2.8 & 2.8 & 2.7 & 2.7 \\
Domestic income transfers & 26.3 & 27.1 & 27.0 & 26.1 & 25.5 & 24.9 \\
Income transfers abroad & 2.3 & 2.2 & 2.3 & 2.2 & 2.2 & 2.2 \\
Subsidies & 2.3 & 2.3 & 2.1 & 2.0 & 1.3 & 1.2 \\
Interest payments & 6.0 & 6.0 & 6.2 & 6.0 & 6.0 & 5.6 \\
Capital transfers and lending & 2.3 & 2.1 & 2.0 & 1.9 & 1.8 & 1.5 \\
& & & & & & \\
Statistical discrepancies & 0.9 & 0.3 & 0.0 & 0.1 & 0.5 & 0.5 \\
& & & & & & \\
Balance (EMU) & -2.9 & -3.9 & -3.2 & -3.4 & -4.0 & -2.3 \\
& & & & & & \\
\hline & & & & & &
\end{tabular}

Source: Central Planning Bureau, Central Economic Plan 1997; and staff estimates. 
Table 17 Netherlands: Expenditures of General Government:

Functional Classification

(In percent of GDP)

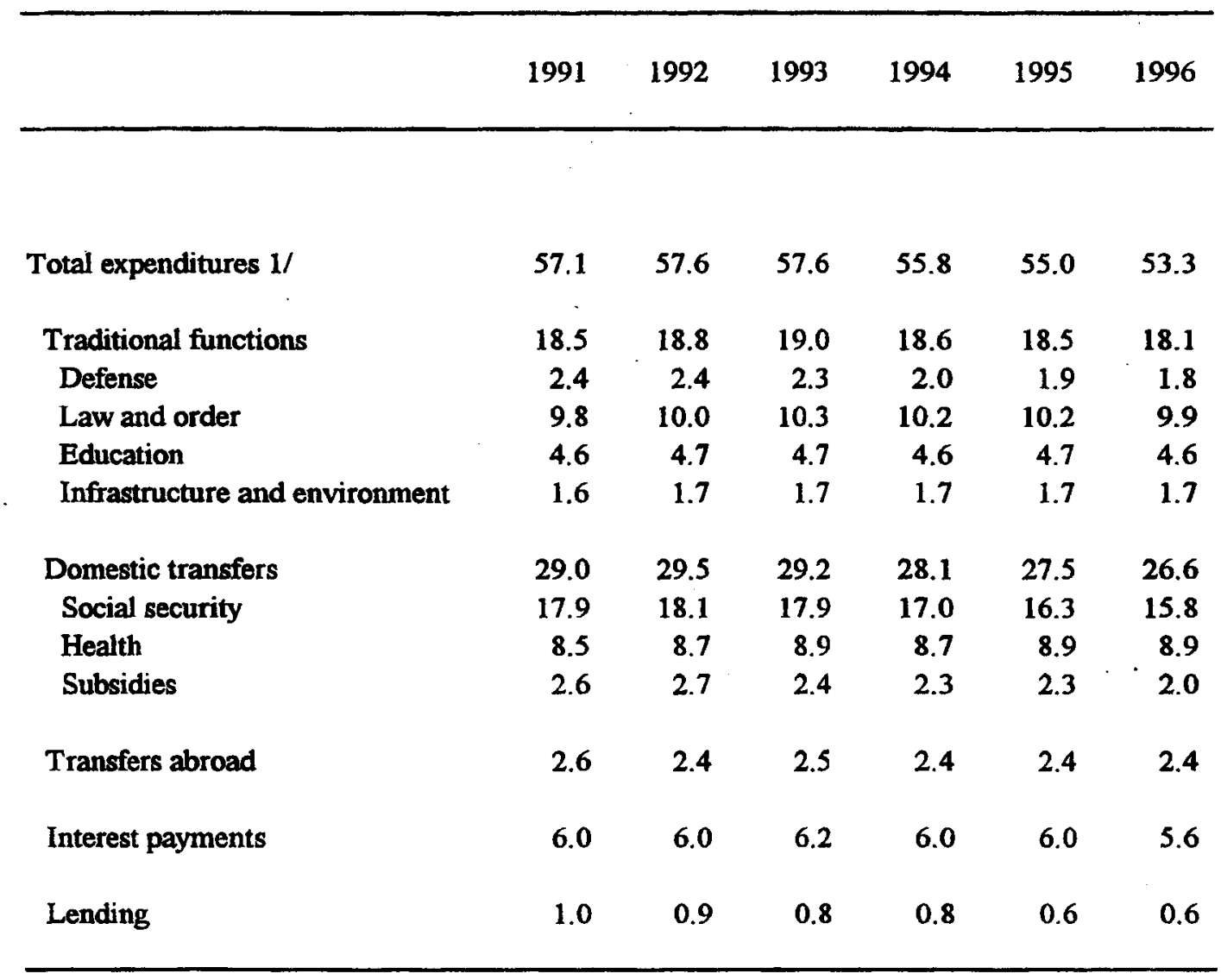

Sources: Central Planning Bureau, Central Economic Plan 1997.

1/ Differences with total expenditures In Table A13 are due to statistical discrepancies. 
Table 18 Netherlands: Deficit and Debt of General Government

(In percent of GDP)

\begin{tabular}{lrrrrrr}
\hline & 1991 & 1992 & 1993 & 1994 & 1995 & 1996 \\
\hline Balance (EMU) & & & & & & \\
Central government & -2.9 & -3.9 & -3.2 & -3.4 & -4.0 & -2.3 \\
Social security funds & -3.4 & -4.2 & -2.9 & -3.2 & -3.7 & -2.0 \\
Local authorities & 0.4 & 0.2 & -0.4 & -0.3 & -0.5 & -0.3 \\
& 0.1 & 0.1 & 0.1 & 0.1 & 0.2 & 0.0 \\
Public debt & & & & & & \\
Gross (consolidated) 1/ & & & & & & \\
Long term 2/ & 76.3 & 77.0 & 78.0 & 74.6 & 77.8 & $\ldots$ \\
$\quad$ Central government & 74.8 & 75.9 & 76.3 & 71.6 & 73.6 & $\ldots$ \\
$\quad$ Local authorities & 61.8 & 62.9 & 62.9 & 58.8 & 60.5 & 59.1 \\
$\quad$ Intra-government debt & 22.5 & 22.1 & 21.0 & 18.1 & 13.3 & $\ldots$ \\
Short term 2/ & 9.5 & 9.1 & 7.6 & 5.2 & 0.2 & $\ldots$ \\
$\quad$ Central government & 1.5 & 1.1 & 1.7 & 3.0 & 4.2 & $\ldots$ \\
$\quad$ Local authorities & 0.6 & 0.3 & 1.0 & 2.3 & 3.4 & 4.3 \\
$\quad$ Intra-government debt & 1.0 & 0.8 & 0.7 & 0.9 & 0.8 & $\ldots$ \\
& 0.1 & 0.1 & 0.1 & 0.3 & 0.0 & $\ldots$ \\
Net (consolidated) 1/ & & & & & & \\
Central government & 72.4 & 73.6 & 73.5 & 70.1 & 72.5 & $\ldots$ \\
Local authorities & 59.3 & 60.5 & 60.4 & 57.7 & 59.7 & 60.8 \\
Intra-government debt & 22.7 & 22.1 & 20.7 & 17.9 & 13.1 & $\ldots$ \\
Gross (EMU) & 9.6 & 9.1 & 7.6 & 5.5 & 0.2 & $\ldots$ \\
& & & & & & $\ldots$ \\
\hline & 78.8 & 79.6 & 80.8 & 78.9 & 79.7 & 78.0 \\
\hline & & & & & & \\
\hline & & & & & & \\
\hline
\end{tabular}

Sources: Central Planning Bureau, Central Economic Plan 1997; Budget Memorandum 1997; De Nederlandsche Bank, Annual Report 1996; and staff estimates.

1/ Debt of central and local authorities.

2/ By original maturity. 
Table 19 Netherlands: Social Security Expenditure 1/

\begin{tabular}{|c|c|c|c|c|c|}
\hline & 1991 & 1992 & 1993 & 1994 & 1995 \\
\hline \multicolumn{6}{|c|}{ (In percent of GDP) } \\
\hline Total & 24.7 & 25.2 & 25.6 & 24.4 & 23.6 \\
\hline Contribution financed $2 /$ & 20.8 & 21.4 & 21.8 & 20.7 & 20.3 \\
\hline Demographic insurance schemes & 7.0 & 7.1 & 7.1 & 6.7 & 6.7 \\
\hline Sick leave and disability insurance & 6.2 & 6.2 & 6.1 & 5.2 & 4.9 \\
\hline Unemployment insurance & 1.1 & 1.2 & 1.5 & 1.8 & 1.7 \\
\hline Health care insurance & 6.5 & 6.9 & 7.2 & 7.0 & 7.0 \\
\hline Budget financed & 3.9 & 3.9 & 3.7 & 3.7 & 3.4 \\
\hline Welfare & 2.0 & 1.9 & 1.8 & 1.8 & 1.6 \\
\hline Of which: & & & & & \\
\hline Unemployment & 1.2 & 1.2 & 1.1 & 1.1 & 1.0 \\
\hline Child allowances & 1.2 & 1.2 & 1.2 & 1.1 & 1.0 \\
\hline Employment schemes & 0.6 & 0.6 & 0.6 & 0.5 & 0.5 \\
\hline Other & 0.2 & 0.2 & 0.2 & 0.2 & 0.2 \\
\hline \multicolumn{6}{|c|}{ (Percent change) } \\
\hline Total & $\ldots$ & 6.5 & 4.1 & 0.5 & 0.3 \\
\hline Contribution financed $2 /$ & $\ldots$ & 7.3 & 4.9 & 0.0 & 1.3 \\
\hline Demographic insurance schemes & $\ldots$ & 5.1 & 3.2 & -0.2 & 2.4 \\
\hline Sick leave and disability insurance & $\ldots$ & 3.2 & 1.0 & -9.8 & -2.6 \\
\hline Unemployment insurance & $\ldots$ & 16.8 & 29.7 & 24.6 & 0.3 \\
\hline Health care insurance & $\ldots$ & 11.9 & 6.0 & 3.4 & 3.3 \\
\hline Budget financed & $\ldots$ & 2.6 & -0.6 & 3.3 & -5.1 \\
\hline Welfare & $\ldots$ & -0.5 & -2.5 & 3.3 & -5.5 \\
\hline \multicolumn{6}{|l|}{ Of which: } \\
\hline Unemployment & $\ldots$ & 0.0 & -0.8 & 5.5 & -5.8 \\
\hline Child allowances & $\ldots$ & 6.5 & 1.1 & 3.1 & -7.3 \\
\hline Employment schemes & $\ldots$ & 4.8 & 2.8 & 0.2 & -0.8 \\
\hline Other & $\ldots$ & 5.1 & -2.9 & 13.6 & -1.1 \\
\hline
\end{tabular}

Sources: Social Note 1997; and staff estimates.

1/ Cash basis.

2/ Consolidated. 
Table 20 Netherlands: Social Security: Number of Recipients of Income-Replacing Benefits 1/

\begin{tabular}{|c|c|c|c|c|c|c|}
\hline & 1991 & 1992 & 1993 & 1994 & 1995 & 1996 \\
\hline \multicolumn{7}{|c|}{ (In thousands of persons ) $1 /$} \\
\hline Contribution financed & 3,549 & 3,601 & 3,695 & 3,717 & 3,724 & 3,700 \\
\hline Demographic insurance schemes & 2,216 & 2,246 & 2,275 & 2,298 & 2,320 & 2,341 \\
\hline Sick leave and disability insurance & 1,147 & 1,143 & 1,146 & 1,079 & 1,059 & 967 \\
\hline Unemployment insurance & 186 & 212 & 274 & 340 & 345 & 392 \\
\hline Budget financed & 2,528 & 2,530 & 2,540 & 2,570 & 2,589 & 2,610 \\
\hline Welfare & 516 & 498 & 496 & 505 & 510 & 498 \\
\hline \multicolumn{7}{|l|}{ Of which: } \\
\hline Unemployment & 325 & 308 & 308 & 319 & 328 & $\ldots$ \\
\hline Child allowances & 1,800 & 1,806 & 1,806 & 1,812 & 1,822 & 1,834 \\
\hline Employment schemes & 96 & 107 & 114 & 122 & 132 & 147 \\
\hline Other & 116 & 119 & 124 & 131 & 125 & 131 \\
\hline \multicolumn{7}{|c|}{ (Percent change) } \\
\hline Contribution financed & 2.2 & 1.5 & 2.6 & 0.6 & 0.2 & -0.6 \\
\hline Demographic insurance schemes & 1.6 & 1.4 & 1.3 & 1.0 & 1.0 & 0.9 \\
\hline Sick leave and disability insurance & 2.0 & -0.3 & 0.3 & -5.8 & -1.9 & -8.7 \\
\hline Unemployment insurance & 12.7 & 14.0 & 29.2 & 24.1 & 1.5 & 13.6 \\
\hline Budget financed & -1.5 & 0.1 & 0.4 & 1.2 & 0.7 & 0.8 \\
\hline Welfare & -5.7 & -3.5 & -0.4 & 1.8 & 1.0 & $=-2.4$ \\
\hline \multicolumn{7}{|l|}{ Of which: } \\
\hline Unemployment & -8.5 & -5.2 & 0.0 & 3.6 & 2.8 & 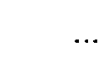 \\
\hline Child allowances & -0.5 & 0.3 & 0.0 & 0.3 & 0.6 & 0.7 \\
\hline Employment schemes & 3.2 & 11.5 & 6.5 & 7.0 & 8.2 & 11.4 \\
\hline Other & -1.7 & 2.6 & 4.2 & 5.6 & -4.6 & 4.8 \\
\hline
\end{tabular}

Source: Social Note 1997.

1/ Converted to full-year equivalents. 
Tablo 21. Netherlands: Monetary Survey

\begin{tabular}{|c|c|c|c|c|c|c|c|c|}
\hline & \multicolumn{8}{|c|}{ December } \\
\hline & 1989 & 1990 & 1991 & 1992 & 1993 & 1994 & 1995 & 1996 \\
\hline , & \multicolumn{8}{|c|}{ (Percent of money supply) $1 /$} \\
\hline $\begin{array}{l}\text { Total inflow of foreign funds } \\
\text { of which: }\end{array}$ & 8.4 & 2.0 & 0.0 & 0.5 & 4.3 & -6.4 & -1.0 & -9.1 \\
\hline Current transections & 5.0 & 3.1 & 2.0 & 2.5 & 4.7 & 3.6 & 3.7 & 3.7 \\
\hline Capital transactions & 4.2 & -0.5 & -2.1 & -3.9 & -7.4 & -8.2 & -4.5 & -4.5 \\
\hline Statistical discrepancies & -0.8 & -0.5 & 0.1 & 1.9 & 7.1 & -2.8 & -0.2 & -8.4 \\
\hline $\begin{array}{l}\text { Domestic liquidity creation. } \\
\text { of which: }\end{array}$ & 3.5 & 5.7 & 5.5 & 5.6 & 3.3 & 6.7 & 5.2 & 14.9 \\
\hline Lending to public authorities & 0.4 & -0.8 & -1.4 & 0.0 & -0.9 & 1.0 & -0.6 & 0.3 \\
\hline Nonbank financial institutions & -0.7 & 0.3 & 0.1 & 0.0 & 0.1 & 0.3 & 1.3 & -0.3 \\
\hline Personal and business sector & 2.5 & 2.2 & 3.2 & 0.8 & -1.2 & -0.6 & 1.4 & 2.5 \\
\hline Long-term operations of banks & 3.4 & 3.1 & 4.1 & 5.5 & 7.8 & 5.3 & 5.1 & 10.2 \\
\hline Miscellaneous 2/ & -2.1 & 0.8 & -0.5 & -0.8 & -2.4 & 0.5 & -2.1 & 2.2 \\
\hline Change in money supply $3 /$ & 12.0 & 7.7 & 5.4 & 6.1 & 7.6 & 0.3 & 4.2 & 5.8 \\
\hline & & & & billio & of gut & (exs) & & \\
\hline Mamorandum itams: $4 /$ & & & & & & & & \\
\hline $\begin{array}{l}\text { Monoy supply (M3) } \\
\text { of which: }\end{array}$ & 359.7 & 386.0 & 407.2 & 432.1 & 465.1 & 466.0 & 486.6 & 515.0 \\
\hline M1 & 119.0 & 123.9 & 129.3 & 135.1 & 149.6 & 152.2 & 172.9 & 193.9 \\
\hline M3 (Percent of GDP) & 74.2 & 74.7 & 75.0 & 76.3 & 80.0 & 26.0 & 76.6 & 77.2 \\
\hline
\end{tabular}

Sources: De Nederlandsche Bank, Annual Report; Quarterly Bulletin; and IMF, International Financial Statistics.

1/ Increase in 12 preceding months as percent of money supply (M3) at beginning of period.

2/ Items in transit and statistical discrepancy.

3 M3, comprising narrow money (M1), time deposits with maturity less than two years, foreign currency deposits, and savings deposits.

4/ Adjusted for breaks in series. 
Table 22. Netherlands: Key Interest Rates

(In percent; averages, unless otherwise indicated)

\begin{tabular}{|c|c|c|c|c|c|c|c|c|c|c|c|}
\hline & \multirow[b]{2}{*}{1991} & \multirow[b]{2}{*}{1992} & \multirow[b]{2}{*}{1993} & \multirow[b]{2}{*}{1994} & \multirow[b]{2}{*}{1995} & \multirow[b]{2}{*}{1996} & \multicolumn{4}{|c|}{1996} & \multirow{2}{*}{$\frac{1997}{I}$} \\
\hline & & & & & & & $\mathbf{I}$ & II & III & IV & \\
\hline \multicolumn{12}{|l|}{ Netherlands Bank rates } \\
\hline Rate on edvances & 8.9 & 8.3 & 5.5 & 4.5 & 3.0 & 2.0 & 2.7 & 2.0 & 2.0 & 2.0 & 2.3 \\
\hline Rate for special loans $1 /$ & 9.5 & 8.6 & 5.8 & 4.8 & 3.5 & 2.5 & 3.0 & 2.6 & 2.5 & 2.5 & 2.8 \\
\hline \multicolumn{12}{|l|}{ Money market rates } \\
\hline Call monoy rate & 9.0 & 9.3 & 7.1 & 5.1 & 4.2 & 2.9 & 3.2 & 2.8 & 2.8 & 2.8 & 2.9 \\
\hline \multicolumn{12}{|l|}{ Aibox 2/ } \\
\hline One-month intexbank rate & 9.2 & 9.4 & 7.1 & 5.2 & 4.3 & 3.0 & 3.2 & 2.8 & 2.9 & 2.9 & 3.0 \\
\hline Three-month interbank rate & 9.3 & 9.4 & 6.9 & 5.2 & 4.4 & 3.0 & 3.2 & 2.8 & 3.0 & 3.0 & 3.1 \\
\hline \multicolumn{12}{|l|}{ Government bond rates } \\
\hline Three to five years & 8.9 & 8.2 & 6.0 & 6.3 & 6.0 & 4.8 & 4.9 & 4.9 & 5.0 & 4.5 & $\cdots$ \\
\hline Benchmark ( 10 years) & 8.7 & 8.1 & 6.5 & 7.2 & 7.2 & 6.5 & 6.6 & 6.7 & 6.6 & 6.1 & 5.9 \\
\hline Five longest bonds & 8.7 & 8.1 & 6.7 & 7.2 & 7.2 & 6.5 & 6.6 & 6.7 & 6.6 & 6.1 & $\cdots$ \\
\hline Bank minimum londing rates $1 /$ & 11.2 & 10.2 & 7.5 & 6.0 & 4.8 & 4.0 & 4.2 & 4.0 & 4.0 & 4.0 & $\cdots$ \\
\hline \multicolumn{12}{|c|}{ Deposit rates at commerclal banks $1 /$} \\
\hline Savings doposite & 2.5 & 2.5 & 2.1 & 2.0 & 2.0 & 1.9 & 2.0 & 1.9 & 1.9 & 1.9 & $\cdots$ \\
\hline \multicolumn{12}{|l|}{ International rates } \\
\hline Three-wonth Eurosullder rate & 9.3 & 9.4 & 6.9 & 5.2 & 4.5 & 3.0 & 3.2 & 2.9 & 3.0 & 3.0 & 3.1 \\
\hline Three-month Eurodollar rate & 6.0 & 3.9 & 3.3 & 4.7 & 6.0 & 5.5 & 5.4 & 5.5 & 5.6 & 5.5 & 5.6 \\
\hline Three-nonth Eurcmerk rate & 9.3 & 9.5 & 7.3 & 5.4 & 4.5 & 3.3 & 3.4 & 3.4 & 3.3 & 3.2 & 3.2 \\
\hline \multicolumn{12}{|l|}{ Memorandum item: } \\
\hline Rate of infletion (CPI) & 3.1 & 3.2 & 2.6 & 2.8 & 1.9 & 2.1 & 1.9 & 1.9 & 2.0 & 2.4 & 2.2 \\
\hline
\end{tabular}

Sources: De Mederlendsche Bank, Quarterly Bulletin and Annual Report; IMF, International Financial Statistics.

1/ End of period.

2/ Amsterdam interbank offer rate. 
Table 23. Netherlands: Exchange Rate Developments

(Perlod averages; changes in percent from same period a year earlier)

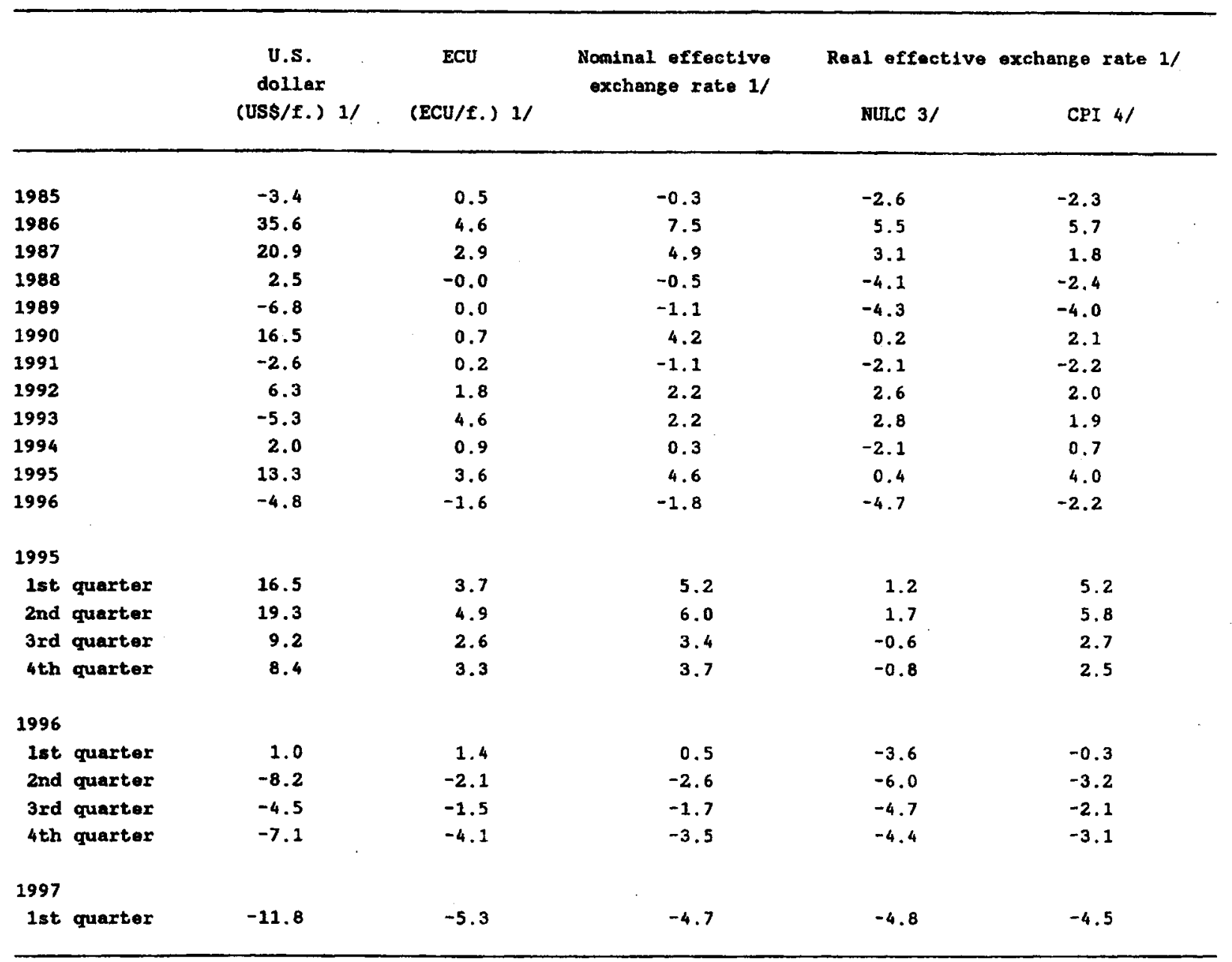

Source: International Monetary Fund, International Financial Statistics.

1/ A positive sign indicates an appreciation of the guilder.

2) Level in percent.

3/ Relative normalized unit labof costs in manufacturing in common currency (total trade weighted).

4/ Relative CPI. 
Table 24. Netherlands: Summary Balance of Payments

(On a cash basis; in billions of guilders)

\begin{tabular}{|c|c|c|c|c|c|c|c|c|c|c|}
\hline & 1987 & 1988 & 1989 & 1990 & 1991 & 1992 & 1993 & 1994 & 1995 & 1996 \\
\hline Merchandise trade & 7.2 & 9.5 & 11.8 & 12.4 & 11.8 & 15.2 & 22.5 & 14.6 & 18.5 & 14.0 \\
\hline Nonfactor services & 0.6 & -0.7 & 2.3 & 5.0 & 2.5 & 4.0 & 5.1 & 6.5 & 7.0 & 9.1 \\
\hline Net factor income & 2.7 & 2.3 & 6.0 & -1.1 & 1.1 & -1.6 & 0.9 & 5.3 & 2.1 & 6.4 \\
\hline Unrequited transfers 1 / & -4.1 & -3.7 & -4.1 & -5.2 & -7.7 & -7.6 & -8.4 & -9.5 & -10.1 & -11.2 \\
\hline Current balance & 6.5 & 7.4 & 16.0 & 11.0 & 7.7 & 10.0 & 20.1 & 16.9 & 17.4 & 18.2 \\
\hline \multicolumn{11}{|l|}{ Nanmonetary sector } \\
\hline Direct investment & -10.9 & -4.5 & -11.9 & -5.0 & -11.8 & -9.9 & -5.3 & -14.1 & -1.0 & -20.4 \\
\hline Securities & 7.3 & 7.8 & 14.5 & -6.9 & -2.2 & -7.1 & -9.0 & -23.6 & -21.3 & -13.7 \\
\hline Capital transfers & -0.5 & -0.4 & -0.7 & -0.5 & -0.5 & -1.1 & -1.3 & -1.8 & -1.9 & -3.2 \\
\hline Other & 0.9 & -2.2 & 10.6 & 8.8 & 4.4 & -7.0 & -6.2 & 2.1 & 2.3 & 4.2 \\
\hline \multicolumn{11}{|c|}{ Balance on nonmonetary } \\
\hline capital & -3.1 & 0.7 & 12.5 & -3.7 & -10.2 & -25.2 & -21.8 & -37.4 & -21.9 & -33.1 \\
\hline Banking sector & 0.4 & -2.3 & -30.1 & -5.4 & -0.9 & 11.3 & 2.5 & 19.6 & 1.5 & 21.8 \\
\hline Direct investment & -0.4 & -0.1 & -1.6 & -0.7 & -1.3 & -1.5 & -1.3 & -3.6 & -3.2 & -2.2 \\
\hline Securities & -2.1 & -1.9 & 1.8 & -1.9 & 0.7 & -9.4 & 12.8 & 5.7 & 3.8 & -8.3 \\
\hline Other & 2.9 & -0.3 & -30.3 & -2.9 & -0.2 & 22.2 & -9.1 & 17.6 & 1.0 & 32.3 \\
\hline \multicolumn{11}{|l|}{$\begin{array}{l}\text { Overall balance (or } \\
\text { change in official }\end{array}$} \\
\hline reserves ) & 5.9 & 3.2 & 1.0 & 0.6 & 0.1 & 10.8 & 12.4 & 0.7 & -2.8 & -9.5 \\
\hline
\end{tabular}

Source: De Nederlandsche Bank, Quarterly Bulletin; and data supplied by the authorities.

1/ Current transfers. 
Table 25. Notherlands: Current Account on Iransactions Basis

\begin{tabular}{|c|c|c|c|c|c|c|c|c|c|c|c|}
\hline & \multirow[t]{2}{*}{1990} & \multirow[t]{2}{*}{1991} & \multirow[t]{2}{*}{1992} & \multirow{2}{*}{1993} & \multirow{2}{*}{1994} & \multirow{2}{*}{1995} & \multirow[t]{2}{*}{1996} & \multicolumn{4}{|c|}{1996} \\
\hline & & & & & & & & I & II & III & IV \\
\hline & \multicolumn{11}{|c|}{ (In billions of guilders) } \\
\hline Trade balance & 21.7 & 22.2 & 21.7 & 31.5 & 34.2 & 33.6 & $\ldots$ & 9.6 & 8.8 & 9.0 & $\ldots$ \\
\hline Energy & -1.0 & 1.0 & -0.3 & -0.7 & 0.1 & 1.1 & .. & 1.1 & 0.9 & 0.1 & $\ldots$ \\
\hline Non energy & 22.8 & 21.2 & 22.0 & 32.2 & 34.1 & 32.4 & $\ldots$ & 8.5 & 7.9 & 8.9 & $\ldots$ \\
\hline $\begin{array}{l}\text { Exports, f.o.b. } \\
\text { (Of which: }\end{array}$ & 236.0 & 243.6 & 241.5 & 237.5 & 258.3 & 280.4 & $\ldots$ & 71.8 & 71.6 & 75.9 & $\cdots$ \\
\hline $\begin{array}{l}\text { Energy exports) } \\
\text { (Of which: }\end{array}$ & 19.7 & 18.7 & 15.4 & 14.9 & 14.8 & 15.9 & $\cdots$ & 5.0 & 4.9 & 4.7 & $\cdots$ \\
\hline Natural gas) & 5.8 & 7.4 & 6.7 & 6.5 & 5.8 & 6.2 & $\ldots$ & 1.8 & 2.2 & 2.5 & $\ldots$ \\
\hline $\begin{array}{l}\text { Imports, f.o.b. } \\
\text { (Of whioh: }\end{array}$ & 214.3 & 221.4 & 219.8 & 206.1 & 224.1 & 246.8 & $\cdots$ & 62.3 & 62.8 & 66.9 & .. \\
\hline Energy (mports) & 20.7 & 17.7 & 15.7 & 15.5 & 14.7 & 14.8 & $\ldots$ & 3.9 & 4.0 & 4.6 & $\ldots$ \\
\hline Services balance & 0.2 & -0.1 & -1.2 & 2.2 & 7.8 & 5.3 & 11.9 & 0.8 & 4.3 & 2.9 & 3.4 \\
\hline Nonfactor services, net & 1.3 & -1.2 & 0.5 & 1.3 & 2.5 & 3.2 & 5.5 & 0.9 & 1.9 & 0.6 & 1.8 \\
\hline Net factor Income & -1.1 & 1.1 & -1.6 & 0.9 & 5.3 & 2.1 & 6.4 & -0.1 & 2.4 & 2.3 & 1.7 \\
\hline Unrequited transfors & -5.2 & -7.7 & -7.6 & -8.4 & -9.5 & -10.1 & -11.2 & -2.7 & -3.0 & -2.5 & -3.0 \\
\hline Private & -1.4 & -1.5 & -1.7 & -1.7 & -1.9 & -1.8 & -1.9 & -0.4 & -0.5 & -0.5 & -0.6 \\
\hline Official transfers & -3.8 & -6.2 & -5.9 & -6.7 & -7.6 & -8.3 & -9.3 & -2.3 & -2.5 & -2.0 & -2.5 \\
\hline Current account balance & 16.7 & 14.4 & 12.9 & 25.3 & $\begin{array}{l}32.5 \\
\text { (In }\end{array}$ & $\begin{array}{l}28.7 \\
\text { percent }\end{array}$ & $\begin{array}{c}\ldots \\
\text { of } \mathrm{GDP}\end{array}$ & 7.7 & 10.2 & 9.4 & $\ldots$ \\
\hline $\begin{array}{l}\text { Trade balance } \\
\text { Nonenergy trade }\end{array}$ & 4.2 & 4.1 & 3.8 & 5.4 & 5.6 & 5.3 & $\ldots$ & 1.5 & 1.3 & 1.4 & $\ldots$ \\
\hline balance & 4.4 & 3.9 & 3.9 & 5.5 & 5.6 & 5.1 & $\ldots$ & 1.3 & 1.2 & 1.3 & $\ldots$ \\
\hline Energy & -0.2 & 0.2 & -0.1 & -0.1 & 0.0 & 0.2 & $\ldots$ & 0.2 & 0.1 & 0.0 & .. \\
\hline Services belance & 0.0 & -0.0 & -0.2 & 0.4 & 1.3 & 0.8 & 1.8 & 0.1 & 0.7 & 0.4 & 0.5 \\
\hline Unrequited transfers & -1.0 & -3.4 & -1.3 & -1.4 & -1.6 & -1.6 & -1.7 & -0.4 & -0.5 & -0.4 & -0.5 \\
\hline Current account balance & 3.2 & 2.6 & 2.3 & 4.3 & 5.3 & 4.5 & $\cdots$ & 1.2 & 1.5 & 1.4 & $\ldots$ \\
\hline
\end{tabular}

Sources: De Nederlandsche Bank, Annual Report and Quarterly Bulletin. 
Table 26. Netherlands: Merchandise Trade (Customs Basis)

(Percentage changes, year-on-year)

\begin{tabular}{|c|c|c|c|c|c|c|c|c|}
\hline & \multirow[t]{2}{*}{1993} & \multirow[t]{2}{*}{1994} & \multirow[t]{2}{*}{1995} & \multirow[t]{2}{*}{1996} & \multicolumn{4}{|c|}{1996} \\
\hline & & & & & $\mathrm{I}$ & II & III & $\overline{I V}$ \\
\hline \multicolumn{9}{|l|}{ Total trade } \\
\hline $\begin{array}{l}\text { Volume } \\
\text { Unit values }\end{array}$ & $\begin{array}{r}8.3 \\
-3.2\end{array}$ & $\begin{array}{l}8.8 \\
0.4\end{array}$ & $\begin{array}{l}9.4 \\
1.9\end{array}$ & $\begin{array}{l}5.4 \\
0.3\end{array}$ & $\begin{array}{l}4.5 \\
0.5\end{array}$ & $\begin{array}{l}0.5 \\
1.2\end{array}$ & $\begin{array}{r}9.8 \\
-1.4\end{array}$ & $\begin{array}{l}6.7 \\
1.0\end{array}$ \\
\hline \multicolumn{9}{|l|}{ Imports } \\
\hline Volume & 4.3 & 10.6 & 10.0 & 6.4 & 7.9 & 1.3 & 9.2 & 7.6 \\
\hline Unit values & -6.1 & 0.1 & 0.5 & 0.9 & 0.1 & 1.9 & 1.3 & 0.4 \\
\hline $\begin{array}{l}\text { Terms of trade } \\
\text { Balance (f.o.b.-c.i.f.) }\end{array}$ & 3.1 & 0.4 & 1.4 & -0.6 & $0.4^{\circ}$ & -0.6 & -2.7 & 0.6 \\
\hline in billions of guilders & 26.7 & 25.8 & 31.2 & 28.1 & 5.6 & 6.9 & 7.3 & 8.3 \\
\hline
\end{tabular}

Source: IMF, International Financial Statistics. 
Table 27. Netherlands: Direction of Trade

(Expressed as percentage of total)

\begin{tabular}{|c|c|c|c|c|c|c|c|}
\hline & 1990 & 1991 & 1992 & 1993 & 1994 & 1995 & 1996 \\
\hline $\begin{array}{l}\text { Exports, total (in billions } \\
\text { of U.S. dollars) } \\
\text { of which: }\end{array}$ & 130.7 & 133.1 & 138.6 & 128.2 & 146.1 & 177.4 & 177.4 \\
\hline $\begin{array}{l}\text { European Union } \\
\text { United Kingdom } \\
\text { France } \\
\text { Germany } \\
\text { Belgium-Luxembourg } \\
\text { United States }\end{array}$ & $\begin{array}{r}80.8 \\
10.2 \\
11.1 \\
28.0 \\
14.7 \\
4.0\end{array}$ & $\begin{array}{r}80.1 \\
9.3 \\
10.7 \\
29.5 \\
14.3 \\
3.9\end{array}$ & $\begin{array}{r}79.7 \\
9.2 \\
10.6 \\
29.0 \\
14.4 \\
4.0\end{array}$ & $\begin{array}{r}75.7 \\
9.2 \\
10.4 \\
28.5 \\
12.5 \\
4.3\end{array}$ & $\begin{array}{r}77.0 \\
9.5 \\
10.6 \\
28.3 \\
13.1 \\
4.2\end{array}$ & $\begin{array}{r}77.4 \\
9.5 \\
10.8 \\
27.9 \\
12.6 \\
3.6\end{array}$ & $\begin{array}{r}78.1 \\
9.3 \\
10.8 \\
28.0 \\
12.9 \\
3.6\end{array}$ \\
\hline $\begin{array}{l}\text { Imports, total (in billions } \\
\text { of U.S. dollars) } \\
\text { of which: }\end{array}$ & 123.4 & 125.5 & 129.8 & 113.3 & 130.8 & 157.7 & 161.0 \\
\hline $\begin{array}{l}\text { European Union } \\
\text { United Kingdom } \\
\text { France } \\
\text { Germany } \\
\text { Belgium-Luxembourg } \\
\text { United States }\end{array}$ & $\begin{array}{r}67.3 \\
8.4 \\
7.9 \\
24.3 \\
14.2 \\
7.8\end{array}$ & $\begin{array}{r}68.2 \\
8.7 \\
7.6 \\
25.7 \\
14.2 \\
7.8\end{array}$ & $\begin{array}{r}69.9 \\
8.8 \\
8.0 \\
25.9 \\
14.7 \\
7.6\end{array}$ & $\begin{array}{r}61.7 \\
8.8 \\
7.0 \\
22.1 \\
10.9 \\
8.7\end{array}$ & $\begin{array}{r}63.1 \\
9.0 \\
7.3 \\
22.4 \\
11.4 \\
8.3\end{array}$ & $\begin{array}{r}62.5 \\
9.5 \\
7.0 \\
22.0 \\
11.1 \\
8.9\end{array}$ & $\begin{array}{r}60.0 \\
9.3 \\
6.9 \\
20.8 \\
10.5 \\
9.1\end{array}$ \\
\hline
\end{tabular}

Source: International Monetary Fund, Direction of Trade. 
Table 28 . Netherlands: Official Development Assistance

(In millions of guilders)

\begin{tabular}{|c|c|c|c|c|c|c|}
\hline & 1990 & 1991 & 1992 & 1993 & 1994 & 1995 \\
\hline Priority programs & 1,544 & 1,030 & 1,097 & 1,246 & 1,107 & 1,427 \\
\hline Country programs & 1,382 & 1,560 & 1,419 & 1,209 & 1,179 & 1,374 \\
\hline Multilateral assistance & 1,059 & 1,305 & 1,388 & 1,266 & 1,409 & 1,490 \\
\hline $\begin{array}{l}\text { Assistance through } \\
\text { private development } \\
\text { organizations }\end{array}$ & 471 & 511 & 529 & 537 & 577 & 614 \\
\hline $\begin{array}{l}\text { Assistance to the } \\
\text { Netherlands Antilles } \\
\text { and Aruba }\end{array}$ & 142 & 207 & 201 & 213 & 130 & 179 \\
\hline $\begin{array}{l}\text { Other development-related } \\
\text { expenses }\end{array}$ & 323 & 332 & 522 & 668 & 544 & 582 \\
\hline Total gross ODA & 4,921 & 4,945 & 5,156 & 5,139 & 4,946 & 5,666 \\
\hline
\end{tabular}

Source: Data provided by the Dutch authorities

1/ Includes priority programs, trade and industry development programs, emergency aid, international education, balance of payments support and export programs. 